Murilo Garavello

Os blogs e o jornalismo de texto: a campanha para a eleição presidencial de 2006 no Brasil

\author{
Universidade de São Paulo \\ Escola de Comunicações e Artes \\ Departamento de Jornalismo e Editoração
}




\title{
Os blogs e o jornalismo de texto: a campanha para a eleição presidencial de 2006 no Brasil
}

\author{
Murilo de Paula Eduardo Garavello
}

\begin{abstract}
Dissertação apresentada ao Programa de Pós-Graduação em Ciências da Comunicação, Linha de Pesquisa Tecnologias da Comunicação e Redes Interativas, da Escola de Comunicações e Artes da Universidade de São Paulo, como exigência parcial para obtenção do Título de Mestre em Ciências da Comunicação, sob a orientação do Profa. Dra. Elizabeth Saad Corrêa.
\end{abstract}

São Paulo, fevereiro de 2009 


\section{TERMOS DE APROVAÇÃO}

Nome do autor: Murilo de Paula Eduardo Garavello

Título da Dissertação: “Os blogs e o jornalismo de texto: a campanha para a eleição presidencial de 2006 no Brasil”

Presidente da banca: Profa. Dra. Elizabeth Saad Corrêa

Banca examinadora:

$\operatorname{Prof}(\mathrm{a}) . \operatorname{Dr}(\mathrm{a})$. Instituição:

$\operatorname{Prof}(\mathrm{a}) . \operatorname{Dr}(\mathrm{a})$. Instituição:

Aprovada em: 
GARAVELLO, Murilo. Os blogs e o jornalismo de texto: a campanha para a eleição presidencial de 2006 no Brasil. São Paulo, 2009. 163 p. Dissertação (Mestrado em Ciências da Comunicação) - Escola de Comunicações e Artes, Universidade de São Paulo. 


\section{Resumo}

Por facilitarem radicalmente a publicação online, os blogs configuram-se como uma das principais ferramentas de um novo panorama comunicativo baseado em uma participação efetiva de cidadãos das mais diferentes formações na produção de conteúdo. Para determinar se, nos dois meses que antecederam a eleição presidencial de 2006 no Brasil, o potencial de os blogs introduzirem novos atores na esfera pública efetivou-se, foi procedida uma análise do conteúdo dos principais jornais, revistas e portais do Brasil, além dos quatro blogs de maior destaque no período. Conclui-se que, estritamente no campo desta pesquisa, poucas novas vozes lograram superar a barreira da recepção.

Palavras-chave: blogs, jornalismo, esfera pública, Brasil, eleições. 


\section{Abstract}

For making online publication extremely easy, blogs are one of the most important tools of a new communication paradigm based on the effective participation of individuals from different backgrounds in the production of online content. In order to determine blog's potential in introducing new actors in the public sphere, a series of content analysis were processed on the most important newspapers, magazines and websites, besides the four most influential blogs, during that timeframe. The conclusion is, strictly in the universe of this research, few new voices could overcome the reception barrier.

Keywords: blogs, journalism, public sphere, Brazil, elections. 


\section{Para:}

Priscila e a bebê Papai, Mamãe, Anita e Homero Vó Toni, Vô Zé e Vó Bila

Agradeço:

à Beth, minha orientadora desde o princípio ao Luli, grande inspirador 


\section{Sumário}

$\begin{array}{ll}\text { Introdução } & 9\end{array}$

Capítulo 1 - Sobre a dissertação 16

1.1 - Objeto da pesquisa e objetivos 16

$\begin{array}{ll}1.2 \text { - Metodologia } & 18\end{array}$

$\begin{array}{ll}\text { 1.2.1 - A primeira análise de conteúdo } & 18\end{array}$

$\begin{array}{ll}1.2 .2 \text { - A segunda análise de conteúdo } & 29\end{array}$

1.3 - Justificativas e delimitações 31

$\begin{array}{ll}\text { 1.3.1 - A escolha da campanha presidencial } & 31\end{array}$

1.3.2 - Campanha eleitoral como cenário $\quad 32$

1.3.3 - Eleições e opções $\quad 33$

1.3.4 - A cauda longa 34

$\begin{array}{ll}1.3 .5 \text { - Jornalismo de texto } & 36\end{array}$

1.3.6 - A ausência de debate sobre as definições de jornalismo 37

1.3.7 - Os EUA e o Brasil 38

1.3.8 - Os padrões e traduções neste trabalho 39

Capítulo 2 - Os blogs e suas peculiaridades $\quad 40$

2.1 - 0 que é blog? $\quad 40$

2.2 - Características e atrativos $\quad 45$

2.2.1 - Publicação fácil e instantânea 46

2.2.2 - Da interação às comunidades $\quad 47$

2.2.3 - Identidade e subjetividade, cultura da exposição 57

2.2.4 - Multiplicidade de usos $\quad 59$

$\begin{array}{ll}2.3 \text { - Audiência e visibilidade } & 71\end{array}$

Capítulo 3 - O novo cenário comunicativo e o jornalismo contemporâneo 78

3.1 - O foco é o usuário: a Internet como plataforma para o saber coletivo 78

3.2 - O jornalismo contemporâneo $\quad 85$

3.2.1 - Veículos colaborativos com viés noticioso $\quad 87$

$\begin{array}{lr}3.2 .2 \text { - Os blogs } & 91\end{array}$

3.2.3 - O jornalismo tradicional e os novos desafios 104

3.2.4 - A grande imprensa e os blogs 112

Capítulo 4 - Os procedimentos analíticos $\quad 122$

4.1 - a primeira análise de conteúdo: os blogs na mídia de texto 122

$\begin{array}{ll}4.1 .1 \text { - As revistas e os blogs } & 122\end{array}$

$\begin{array}{ll}4.1 .2 \text { - Os jornais e os blogs } & 124\end{array}$

$\begin{array}{ll}4.1 .3 \text { - Os portais e os blogs } & 131\end{array}$

4.2 - A segunda análise de conteúdo: os blogs mais influentes 135

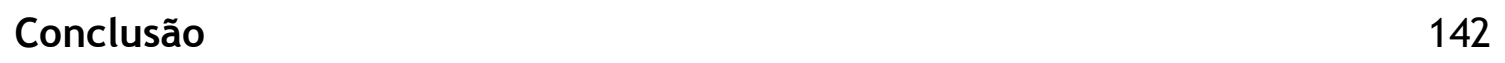

$\begin{array}{ll}\text { Bibliografia } & 148\end{array}$ 


\section{Introdução}

0 mundo se povoa de imagens, mensagens, colagens, montagens, bricolagens, simulacros e virtualidades. (...) Por sobre a coleção de caleidoscópios locais, nacionais, regionais ou continentais, justapostos e estranhos, semelhantes e opostos, estende-se um vasto caleidoscópio universal, alterando e apagando, bem como revelando e acentuando cores e tonalidades, formas e sons, espaços e tempos desconhecidos em todo o mundo. Entrecruzam-se, fundem-se e antagonizam-se perspectivas, culturas, civilizações, modos de ser, agir, pensar, sentir e imaginar. Tanto se apagam e recriam diversidades preexistentes como formam-se novas. Ao mesmo tempo que expressa e deflagra processos de homogeneização, provoca diversidades, fragmentações e antagonismos" (IANNI, 2004, p. 27-32).

0 trecho descrito acima, em que Octavio lanni postula características do que denomina "era do globalismo", poderia servir também para enunciar o ambiente forjado pelo advento e desenvolvimento da Internet, símbolo da sociedade global e, ao mesmo tempo, um de seus principais subprodutos e catalisador dos processos que moldam e revolucionam a realidade e o imaginário do homem contemporâneo.

Se o caráter aberto, público, descentralizado e aparentemente ilimitado da rede das redes desde seus primórdios encorajou a disseminação de diversas teorias de renovação e fortalecimento da democracia, um dos mais relevantes entre os múltiplos efeitos do transcurso de mais de uma década desde sua popularização, sob a vigência do "ciclo de realimentação cumulativo entre a inovação e seu uso" (CASTELLS, 1999, p. 69), que aumenta exponencialmente a velocidade das mudanças tecnológicas e seu impacto sobre a sociedade, consiste na enorme ampliação das possibilidades de o cidadão deixar de atuar apenas como um recipiente passivo de cultura, passando do estágio "somente leitura" 
para "ser tanto ler quanto escrever", na metáfora empregada por Lessig (2004, p. 37). Mais do que só ler e escrever, hoje um cidadão com acesso à Internet pode, sem pagar nada e efetuando processos relativamente simples, veicular vídeos (por meio de sites como o You Tube ${ }^{1}$ ), produzir programas de rádio (via podcast ${ }^{2}$ ), construir uma página pessoal (usando blogs), escrever em enciclopédias online (como a Wikipedia ${ }^{3}$ ), publicar notícias em grandes portais (no Brasil, com o Minha Notícia ${ }^{4}$, do IG, por exemplo) e compartilhar fotos (em sites como o Flickr ${ }^{5}$ ). Além disso, as emergentes possibilidades de transferência instantânea de dados e informações, aliadas a dispositivos que permitem aos seres humanos a colaboração nas mais diferentes formas nas mais diversas áreas, reforçam utopias como a da “inteligência coletiva” de Lévy (1998, p. 28-29). “O potencial mais profundo de transformação de conectar as propensões sociais dos humanos com a eficiência das informações tecnológicas é a chance de se fazer novas coisas juntos, cooperar em escalas e em meios nunca antes possíveis" (RHEINGOLD, 2002, p. 157-158).

Neste cenário, não são poucos os autores que apontam o potencial da Internet para reabilitar, viabilizar e concretizar a esfera pública habermasiana. Afinal, nunca os cidadãos dispuseram de tantas ferramentas para discutir questões de interesse público sem a intermediação direta dos grandes conglomerados de comunicação, estabelecendo um processo de fluxo informativo multidirecional, dispensando a necessidade de encontros presenciais e mesmo sincrônicos -e

\footnotetext{
${ }_{1}^{1}$ http://www.youtube.com. Acesso em 19 jun.2007.

2 Um podcast é um arquivo de mídia digital, ou uma série deles. São facilmente manipuláveis e podem ser reproduzidos em computadores ou em aparelhos aptos a executarem arquivos de música no formato MP3.

${ }^{3} \mathrm{http}: / /$ wikipedia.org/. Acesso em 19 jun.2007.

${ }^{4}$ http://minhanoticia.ig.com.br/index.html. Acesso em 19 jun.2007.

5 http: / /flickr.com/. Acesso em 5 nov.2008.
} 
propiciando a colaboração de indivíduos distantes geograficamente ou com formações culturais muito distintas-, com a opção de trocar rapidamente enormes quantidades de conteúdo (em qualquer formato de mídia) e conhecimento para dar suporte a decisões embasadas, podendo usar plataformas diferentes -algumas propícias a discussões pontuais, outras ideais para debates abrangentes-, entre muitas outras vantagens. Com diferentes enfoques, ênfases e conclusões, SASSI (2001), BRITTES (2003), RODRIGUES (2006), LÉVY (1998), JERECZEK-LIPINSKA (2007), SILVEIRA (2007), MONTEZ e GAMA (2006), BAUMAN (2001), BOLAÑO e BRITTOS (2008), OROSA e GARCÍA (2004), entre muitos outros, abordam o tema, reconhecendo o potencial revolucionário do impacto da introdução de milhões de novas vozes no espaço público, com visões otimistas ou não tanto sobre o futuro da democracia com a expansão e desenvolvimento da Internet.

Os blogs são uma das mais inovadoras tendências do novo século (...). Quando uma ferramenta de comunicação pública consegue um impacto social de tal magnitude que transforma a cultura, então se converte em um meio. Assim como o livro, o rádio, a televisão, o cinema, o vídeo, o disco ou a imprensa, o weblog é um meio que, valendo-se da plataforma web, desenvolve sua própria linguagem e transforma a cultura (ORIHUELA, 2006, p. 65).

Ao permitirem que cada indivíduo com acesso à rede mundial de computadores possa dispor de um ou mais espaços pessoais para publicar o que bem entender, em um processo simples, rápido, sem intermediários e "tão fácil quanto enviar um e-mail” (ORIHUELA, 2006, p. 27), os blogs, objeto deste trabalho, estabelecem-se como uma das principais ferramentas deste novo panorama comunicativo baseado na participação efetiva do cidadão na produção 
e distribuição de conteúdo online. Além da facilidade e da liberdade de publicação, outras características, como a multiplicidade de usos e a interação com o estabelecimento de conversações e a formação de comunidades- podem auxiliar a compreensão dos motivos do crescimento exponencial da blogosfera e o potencial de impacto sobre diversas esferas da vida humana. Nos mais de 133 milhões de blogs existentes no mundo (MADANSKY e ARENBERG, 2008) aflora um caleidoscópio amplo, colorido e multifacetado de participantes, usos e idéias que poderia servir como uma definição da criatividade humana: de garotas que festejam o primeiro beijo a bandas que buscam o sucesso, de presidentes de grandes empresas que orientam funcionários a prostitutas que querem atrair clientes, de testemunhas que relatam catástrofes a mães grávidas que dividem sua emoção, de celebridades a ilustres desconhecidos; da educação à cultura, da política à ciência, do entretenimento ao jornalismo, do esporte à informática; do diário pessoal à divulgação de notícias, da promoção de um produto a uma denúncia de corrupção, para contar piadas ou conseguir doações. "Blog é meramente uma ferramenta que permite que você faça qualquer coisa, de mudar o mundo a compartilhar sua lista de compras. As pessoas o usarão como quiserem" (JARVIS, 2005).

Para o jornalismo, outro dos eixos desta dissertação, a expansão da blogosfera introduziu uma série de novas variáveis, a maior parte delas desdobramentos do cenário comunicativo que torna mais tênues as fronteiras entre produtores e consumidores de informação. Modificaram-se as relações entre as empresas informativas para as quais os jornalistas trabalham, que 
anteriormente detinham o monopólio da veiculação de notícias, e seu público, que de receptor passivo passou a exercer um papel duplo de produtor e consumidor de conteúdo. No que se refere especificamente aos blogs, multiplicaram-se as fontes de referência, tanto de conhecimento quanto de termômetro de reação a determinadas notícias; em diversos casos de catástrofes ambientais ou eventos de grande repercussão, testemunhas ou afetados escolheram os blogs para veicular depoimentos, fotos e vídeos que, por vezes, foram os primeiros elementos concretos a chegar a público sobre o fato em questão; cidadãos podem utilizar blogs para falar sobre eventos micro-locais, em geral ignorados pela imprensa, como um campeonato de colégio ou um encontro de apreciadores de vinho; em dispositivos e práticas da blogosfera, como a facilidade de feedback propiciada pelos comentários, a rapidez de postagem e atualização das páginas e a transparência proporcionada pelos links para fontes referenciadas são mecanismos úteis para o jornalista e para os veículos de comunicação; a colaboração entre blogueiros empenhados já produziu uma série de revelações em cadeia sobre assuntos de interesse público que, em seguida, viraram notícias nos maiores veículos de comunicação.

Por outro lado, a multiplicação dos blogs e de outros tipos de página leva a um crescimento enorme da oferta de endereços no ciberespaço. Obviamente, ninguém consegue ler tudo. E esta é uma das questões importantes para esta dissertação: em que medida o deslocamento da barreira "do momento da produção para o momento da recepção" (SERRA, 2003a, p. 91) afeta o acesso do público em geral às milhões de novas vozes emergentes? Um dos pilares 
para o estabelecimento do modelo habermasiano de esfera pública é que os atores sociais interajam "de modo equilibrado entre si, com idênticas oportunidades participativas" (BRITTES, 2003, p. 43). Todos que consigam acessar a Internet já dispõem de meios para publicar, mas têm as mesmas chances de serem lidos?

Este trabalho, dividido em quatro capítulos, busca analisar as características dos blogs, as potenciais conseqüências de seu advento para o jornalismo neste novo panorama comunicativo e, utilizando como corpus de pesquisa a campanha para o primeiro turno das eleições presidenciais de 2006 no Brasil, verificar se já se registravam alguns destes efeitos. Além disto, a pesquisa busca constatar, estritamente no âmbito do universo analisado, se a existência da blogosfera propiciou a introdução de algumas das vozes emergentes no universo dos principais veículos de jornalismo de texto do país.

No primeiro capítulo, serão determinados os objetivos, as questões fundamentais, a delimitação do tema e suas justificativas, e a metodologia empregada nesta dissertação. No segundo, serão abordados especificamente os blogs: sua origem, suas definições, os atrativos que levam milhões de pessoas no mundo a adotá-los, como a facilidade de publicação, a possibilidade de estabelecimento de conversações, a multiplicidade de usos e a propriedade de configurarem um espaço do eu na Internet, além da questão da audiência e visibilidade em um ambiente ciberespacial cada vez mais repleto de páginas e informações. No terceiro capítulo, serão detalhadas as características do novo panorama comunicativo e seus impactos no jornalismo, bem como os usos de 
blogs especificamente relacionados com o universo jornalístico e a relação deles com o jornalismo tradicional. No quarto capítulo, serão expostos os resultados de dois procedimentos metodológicos efetuados, que buscaram medir o papel dos blogs na cobertura da campanha para o primeiro turno da eleição presidencial no Brasil pelos maiores jornais, revistas e portais do país e abordar especificamente os blogs mais referenciados pelos veículos de comunicação analisados. 


\section{Capítulo 1 - Sobre a dissertação}

\section{1 - Objeto da pesquisa e objetivos}

Como será demonstrado ao longo deste trabalho, as propriedades dos blogs e sua crescente adoção geram uma série de conseqüências potenciais para o jornalismo. No mundo, e principalmente nos EUA, centro de boa parte das inovações tecnológicas recentes no campo das mídias digitais, uma parcela destes potenciais vem se concretizando, com cidadãos de diferentes formações obtendo voz, participando do processo de veiculação de informações e influindo em processos políticos por meio dos blogs. À luz deste potencial da blogosfera, este trabalho utilizou a campanha e a eleição presidencial brasileira de 2006 como campo de pesquisa para levantar e analisar os papéis exercidos pelos blogs, objetos deste estudo, no conteúdo dos maiores sites noticiosos e sua repercussão no produto final dos jornais e revistas mais influentes do país, verificando de que forma e em que situações foram empregados ou referenciados. Tomando como ponto de partida o pressuposto de que o blog é uma ferramenta que facilita a veiculação de opiniões, o trabalho abriu duas frentes de pesquisa para: 1) verificar que espécies de blogs, alimentados por cidadãos de que formação, ganharam repercussão na mídia de texto brasileira; 2) analisar blogs de jornalistas consagrados vinculados aos tradicionais veículos de comunicação para a constatação de sua natureza, checando se, durante o período de análise, limitaram a configurar-se como transposições para a Internet das colunas escritas para jornais ou revistas ou se utilizaram o repertório de inovações que conduziu os blogs a constarem na linha de frente das novas tendências do jornalismo por 
permitirem a aproximação entre produtores e leitores de notícias e propiciarem “conversações” com leitores em vez de monólogos.

Com a primeira frente de trabalho, a pesquisa almejou responder, estritamente no âmbito da campanha presidencial de 2006 no Brasil, às seguintes questões: como a blogosfera foi aproveitada pelos grandes portais de Internet? Blogs de desconhecidos, jornalistas ou não, receberam destaque? Ou apenas nomes previamente consagrados lograram alcançar os espaços nobres dos sites? $\mathrm{E}$ quanto aos jornais e revistas, aproveitaram-nos em suas reportagens? Alguma denúncia realizada por blog ganhou repercussão? Algum blogueiro desprovido de credenciais que o tornassem conhecido do público conseguiu, por meio de seu blog, ser citado pelos veículos de mídia de texto?

Já o segundo procedimento analítico buscou dar respostas às perguntas elaboradas a seguir: os blogs de profissionais remunerados pelas empresas tradicionais utilizaram ferramentas e adotaram práticas fundamentais ao estabelecimento e consolidação da blogosfera como um novo canal para a expressão de opiniões, fatos e notícias? Com que freqüência estes blogs deram links para outras fontes de notícias e para outros blogs? Quantas vezes o editor do blog fez menção em seus posts a comentários deixados por leitores ou modificou alguma análise ou notícia a partir de uma manifestação do público? Quantas vezes os comentários de leitores obtiveram resposta (no campo específico de comentários dos leitores)? Usaram dispositivos e ferramentas auxiliares à blogosfera? Procuraram inserir-se em comunidades? 


\section{2 - Metodologia}

\subsection{1 - A primeira análise de conteúdo}

Para a coleta de dados direcionada a cumprir os objetivos desta pesquisa, optou-se por utilizar a "análise de conteúdo" para levantar todas as referências a blogs em contextos relacionados à cobertura da campanha presidencial em jornais e revistas escolhidos, bem como todos os links para blogs nos portais selecionados, durante o período analisado, que versassem sobre temas correlatos ao campo de pesquisa. Os dados foram reunidos por meio da observação direta e não-participante: apesar de o autor ser funcionário de um dos portais (UOL) integrante do corpus, atuava em outra área e não participou de nenhum tipo de decisão vinculada à cobertura das eleições.

Devido à limitação inerente à execução individual deste trabalho, foi adotado um procedimento analítico qualitativo, com a coleta de dados limitada aos veículos de comunicação de maior circulação ou audiência nas áreas pertinentes (jornais, revistas e portais). De acordo com o IVC (Instituto Verificador de Circulação), ao qual estão afiliadas todas as principais publicações brasileiras, a Folha de São Paulo foi o jornal de maior circulação em 2006 no Brasil, com uma média diária de 309.383 exemplares, seguido por 0 Globo, que registrou circulação média diária de 276.385 no ano. Ainda segundo o IVC, entre as revistas brasileiras, nenhuma vendeu mais exemplares do que a Veja em 2006: uma média de circulação de 1.105.337 exemplares por edição. A Época foi a segunda colocada, com circulação média de 433.584 exemplares. Daí as duas

\footnotetext{
${ }^{6}$ Método positivista que teve origem no século XVIII e passou a ser usado com freqüência no século XX, a análise de conteúdo é uma técnica de investigação que busca descrever um conteúdo de maneira objetiva, sistemática e reprodutível.
} 
representarem seu segmento nas análises efetuadas para esta dissertação. Para a definição dos portais a serem analisados, utilizou-se, mediante autorização formal do Ibope, dados da pesquisa mensal elaborada pelo instituto em parceria com o norte-americano Nielsen NetRatings. Com audiência domiciliar ${ }^{7}$ de 8,889 milhões de visitantes únicos ${ }^{8}$, o $\mathrm{UOL}^{9}$ foi o portal nacional de maior audiência em julho de 2006, mês que antecedeu o início da pesquisa e, por isso, foi adotado como parâmetro. 0 Terra $^{10}$, com 7,688 milhões de visitantes únicos, ocupava a segunda posição no mesmo período. $\mathrm{E}$ o IG ${ }^{11}$, com 6,692 milhões de visitantes únicos, era o terceiro colocado, com mais de 1 milhão e 100 mil visitantes únicos a mais do que o quarto, o portal da Globo, que somava 5,568 milhões. Assim, UOL, Terra e IG foram os portais escolhidos para análise.

O período de coleta de dados estendeu-se de $1^{\circ}$ de agosto a $1^{\circ}$ de outubro de 2006, ou seja, contemplou os dois meses anteriores ao primeiro turno do pleito, realizado em $1^{\circ}$ de outubro de 2006. Entre os jornais, foram analisadas 62 edições da Folha de S.Paulo e 62 edições de 0 Globo, especificamente os cadernos de política dos dois jornais -denominados "Brasil", pela Folha, e "O País”, por 0 Globo. Os dois jornais não veicularam cadernos especiais para a cobertura de eleições regularmente -quando houve a publicação, os cadernos foram incluídos no corpus. Eventuais citações a blogs em outras editorias dos jornais não estão contempladas neste estudo. Entre as revistas, nove edições de

\footnotetext{
7 A pesquisa é restrita aos usuários domiciliares. Portanto, acessos de escritórios, universidades e cybercafés, por exemplo, não são contemplados.

${ }^{8} \mathrm{O}$ conceito de "visitantes únicos" é baseado no número de indivíduos que acessaram determinada página, independentemente do número de visitas feitas. Em 2008, era a métrica mais valorizada tanto pelos portais quanto pelo mercado publicitário nacional.

${ }^{9}$ http://www.uol.com.br/. Acesso em 25.jun.2007.

${ }_{11}^{10}$ http://www.terra.com.br/capa/. Acesso em 25 jun. 2007.

11 http://www.ig.com.br. Acesso em 25 jun. 2007.
} 
Veja e Época foram alvo de análise -o pesquisador leu as 18 edições na íntegra. Já os portais apresentam algumas especificidades. Como o conteúdo de suas páginas principais é alterado constantemente, estabeleceu-se um horário diário, sempre entre $18 \mathrm{~h} 45$ e $19 \mathrm{~h} 30$, para a coleta de dados. As páginas principais e dos canais específicos de eleições veiculadas por UOL, Terra e IG foram gravadas no momento em que o pesquisador as acessou. Evidentemente, o conteúdo de, por exemplo, o IG, poderia ser diferente minutos antes do acesso ou alterado logo depois, ainda dentro dos 45 minutos do período estipulado. Para esta análise, entretanto, foram consideradas as versões que estavam disponíveis no exato momento em que foram vistas.

Para respeitar a regra da homogeneidade na análise de conteúdo (DUARTE e BARROS, 2005, p. 293), foram elaborados três tipos de tabela: um para os jornais, outro para as revistas e um terceiro para os portais. As tabelas, que contêm diferenças entre si, são adaptações do modelo proposto por DUARTE e BARROS (2006, p. 296-297). Ao fim do período de análise, os dados das 372 tabelas de portais, 124 de jornais e 18 de revistas foram tabulados por meio da agregação manual em uma planilha do programa Excel, da Microsoft. Os principais resultados estão expostos no capítulo 4. 


\section{Tabela 1 - Modelo para monitoramento dos jornais}

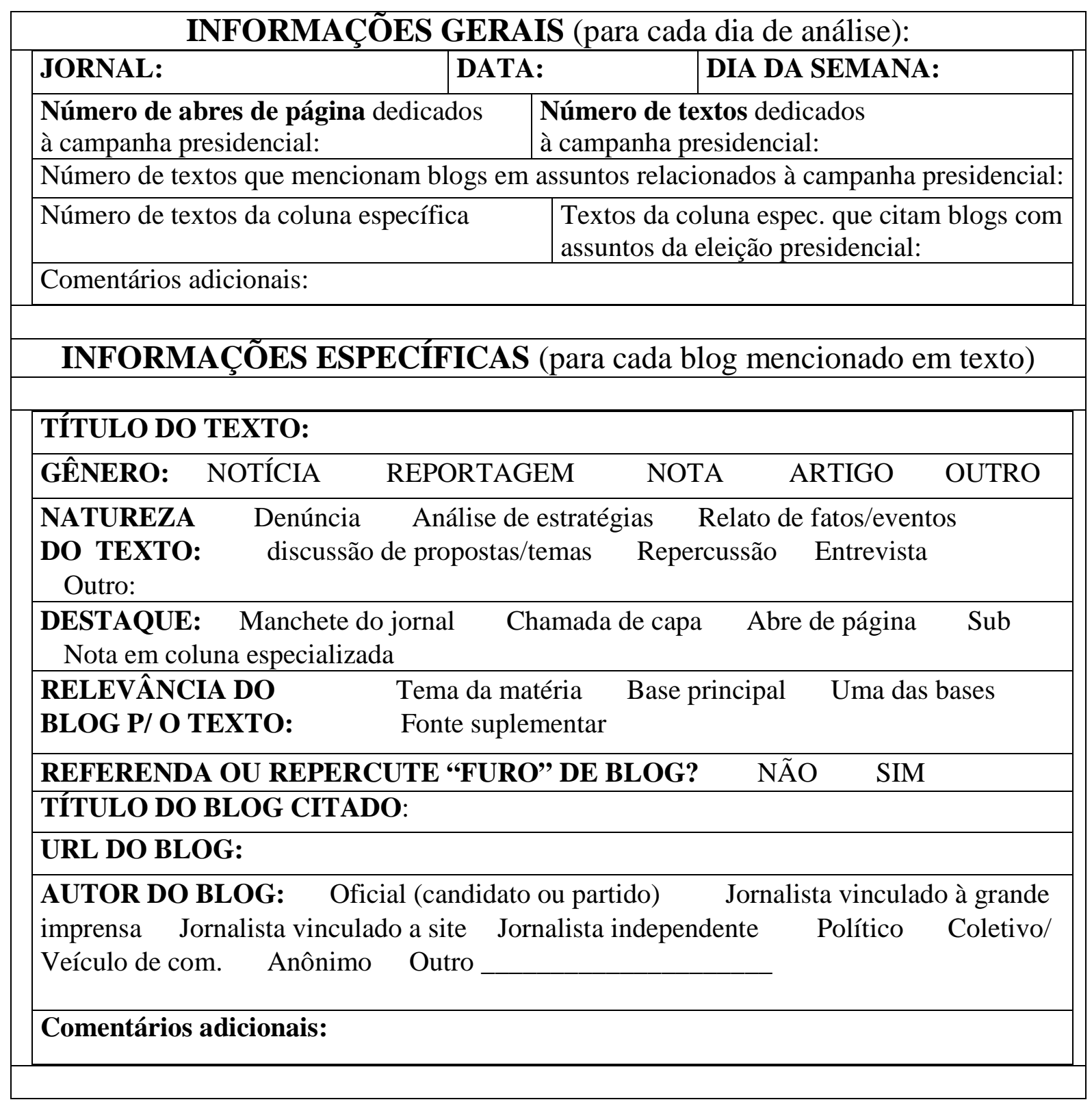

A partir da leitura diária dos jornais, foi preenchida a tabela 1. Para melhor compreensão dos resultados faz-se necessário explicitar cada um dos critérios adotados: 
a) Número de abres de página: foram considerados como "abres de página" os textos localizados no topo, configurando-se como o principal conteúdo da página, e que versassem sobre a campanha presidencial ou contivessem assunto diretamente relacionado a ela. Aqui, são importantes outras explicações: matérias que mencionaram um dos candidatos à Presidência foram consideradas "assuntos relacionados à campanha presidencial", mesmo que o tema abordado não se referisse à disputa em si. Exemplo: uma reportagem sobre a gestão do candidato Geraldo Alckmin como governador do Estado de São Paulo que estivesse ao alto de uma das páginas de política de 0 Globo seria computada como "abre de página". Também se avaliou como assunto pertinente reportagens sobre desafios que a situação brasileira trazia ao futuro presidente, mesmo que os candidatos não fossem citados -neste caso, o pleito deveria, necessariamente, estar mencionado.

b) Número de textos dedicados à campanha presidencial: não apenas as reportagens entraram na contabilidade deste estudo. Artigos, editoriais, "boxes" (ou textos complementares) e infográficos -estes quando agregassem informação ao texto, ou seja, quando não se limitassem a reproduzir graficamente dados relatados pelos textos a que se referiam ou não estivessem relacionados a nenhuma matéria- foram considerados como um "texto". Quanto ao assunto, os mesmos critérios explicitados no item "a" foram utilizados. Entretanto, seções de notas, como o "Painel da Folha" ou a coluna "Toda Mídia" na Folha de S. Paulo, ou a "Caiu na rede", de O Globo, foram analisadas separadamente, ou seja, não contaram como "textos". 
c) Coluna específica: cada uma das colunas de notas, como referido no parágrafo anterior, foi computada isoladamente. Em “Toda Mídia”, o jornalista Nélson de Sá, da Folha, comentou, de segunda a sexta-feira (e, às vezes, aos sábados), a cobertura das notícias por outros meios, como TV e Internet. Já 0 Globo publicou sem qualquer periodicidade a coluna "Caiu na Rede" para repercutir informações veiculadas na Internet. O "Painel da Folha”, seção em que são inseridas notas sobre bastidores da política, foi publicado diariamente.

d) Comentários adicionais: espaço híbrido utilizado para a anotação de citações a blog em outros contextos que não a campanha presidencial e outros lembretes pertinentes, como a notícia do lançamento de um blog, por exemplo.

e) Gênero: refere-se ao formato do texto que cita blog ou para explicitar que a menção deu-se em uma nota em coluna específica. É importante ressaltar a diferenciação efetuada entre notícia e reportagem: matérias originárias de investigação jornalística e que tinham como cerne a veiculação de informações desconhecidas do público em geral foram consideradas reportagens; como notícias, foram computados os textos que relatassem eventos e fatos ocorridos no dia anterior, já noticiados por outros veículos de comunicação, ainda que acrescidos de algum detalhe ou enfoque original.

f) Natureza do texto: cada matéria ou artigo que citou blog em um contexto relacionado à campanha presidencial foi encaixada em uma categoria. Quando um texto continha características de duas categorias, foi encaixado na referente ao aspecto predominante. Uma categoria merece menção de forma a se dirimir eventuais dúvidas: "repercussão" refere-se tanto à análise da abordagem que 
blogs deram a um dado assunto quanto ao fato de um dos jornais retomar assunto veiculado pela concorrência ou por outros órgãos de comunicação.

g) Relevância do blog para o texto: refere-se ao uso feito pelo jornal do blog citado. "Tema da matéria" é uma categoria em que se encaixam textos em que se fala sobre blogs ou sobre um determinado blog; "base principal" é um texto para o qual um blog ou informação dele foi a principal fonte para sua construção; "uma das bases", quando, além do blog, outros dados fazem parte da essência da matéria; em "fonte suplementar" foram inseridos textos que citaram blogs, mas o uso deles não era fundamental para sua publicação.

h) "Furo": a palavra, retirada do jargão jornalístico, significa notícia ou informação inédita, ou seja, até então desconhecida do público.

i) "Autor do blog": as categorias buscam explicitar qual (is) a (s) profissão (ões), ou quais são a (s) pessoa (s) que alimenta $(\mathrm{m})$ o blog citado e, ao mesmo tempo, sua vinculação com os candidatos ou com a grande imprensa. 0 item "veículo de comunicação" refere-se aos blogs coletivos de profissionais contratados por empresas tradicionais de imprensa. 
Tabela 2 - Modelo para acompanhamento dos portais

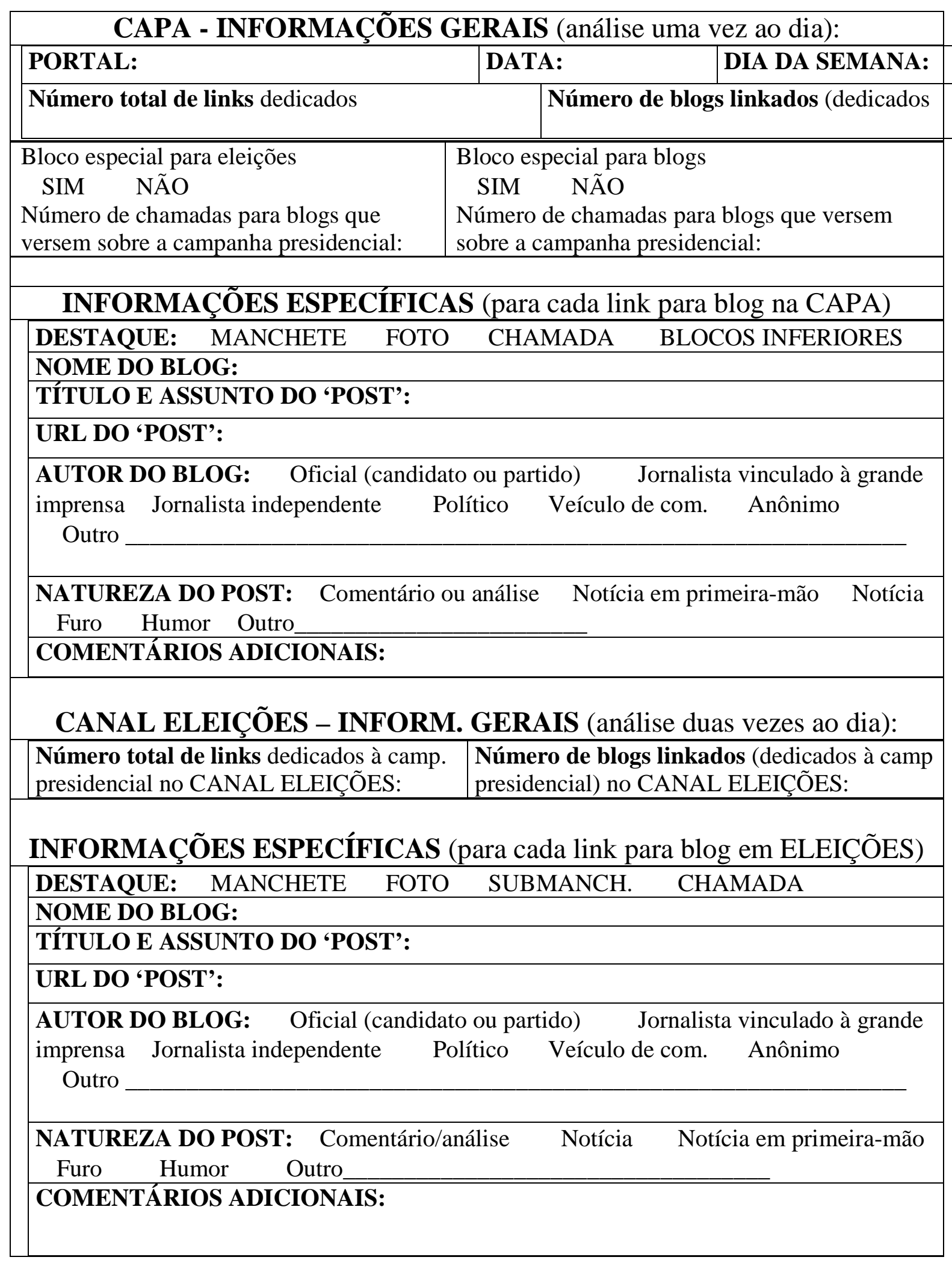


Os três portais de Internet foram objeto de análise durante os 62 dias pelos quais se estendeu o campo da pesquisa. Foram acessadas as páginas principais de UOL e Terra, bem como a capa do canal específico para acompanhamento de eleições que cada um criou (UOL Eleições $2006^{12}$ e Terra - Eleições $2006^{13}$ ). Já o IG, por à época adotar uma dinâmica diferente em sua capa, em que abas temáticas eram colocadas no espaço principal destinado a notícias, recebeu um tratamento um pouco diverso: foram impressas duas de suas versões de primeira página: “1ª página”, que era a disposição default quando o internauta acessava o site, e "Eleições". Como o site disponibilizava logo em sua capa uma seção específica sobre eleições com manchete, sete chamadas e uma foto (ou seja, número de chamadas maior do que a do canal interno criado, "Último Segundo Eleições $2006^{14 »,}$, que continha uma manchete e mais quatro chamadas), optou-se por considerar este o canal de eleições do site. Outro dado sobre o IG que merece desde já ser mencionado é o fato de, durante os 62 dias, o site ter incluído entre as já citadas abas uma denominada "Blogs - Opinião", que não foi objeto de análise específica e, sim, inserida dentro da tabulação de dados da capa como um todo.

Diariamente, arquivaram-se as duas versões de páginas de cada site, e as tabelas foram preenchidas. No que se refere especificamente à tabela usada como modelo para o acompanhamento de blogs, vale destacar:

a) Destaque e blocos especiais: “manchete” é a principal chamada do site. Nos três casos (IG, UOL e Terra) a "manchete" localizava-se ao alto da página,

\footnotetext{
12 http: //eleicoes.uol.com.br/. Acesso em 25 jun. 2007.

13 http: //noticias.terra.com.br/eleicoes2006. Acesso em 25 jun. 2007.

14 http://ultimosegundo.ig.com.br/eleicoes2006/. Acesso em 25 jun. 2007.
} 
com caracteres de texto maiores do que os das outras chamadas; a categoria “foto" refere-se às chamadas veiculadas por meio de fotos; "chamada” inclui as notícias destacadas no bloco principal de cada um dos portais, em que se inseria a manchete; à época da análise, a página principal dos três sites dividia-se em módulos, com um bloco principal (onde ficava a manchete) e outros auxiliares, localizados abaixo do principal. Referências ou links a blogs nestes outros blocos foram consideradas como "blocos inferiores". No caso específico do IG, as abas temáticas, como “Blogs - opinião”, foram consideradas, também, como “blocos inferiores", à exceção da bloco de "Eleições" que, como explicitado anteriormente, inseriu-se na análise como canal específico.

b) Natureza do post: neste item, buscou-se analisar em qual das categorias se encaixava, predominantemente, o post para o qual a chamada na capa ou em um canal específico encaminhava o leitor. Muitas das entradas dos blogs misturavam “notícias” com "análise ou comentário”. Nestes casos, optou-se levar em conta, além da verificação de qual dos tipos prevalecia, o papel que a chamada no site conferia ao post. Há ainda outra observação importante: por "notícia em primeira-mão" deve se entender informações inéditas veiculadas pelo blogueiro, sob uma condição: são notícias, em geral, corriqueiras, que seriam dadas por outros sites e veículos de comunicação posteriormente. Ou seja, nestes casos, o blogueiro aproveitou-se da rapidez do meio para divulgar antes uma informação que de qualquer forma cairia no domínio público. o "furo", em contrapartida, deve ser entendido neste trabalho como uma revelação exclusiva, fruto da apuração jornalística específica de um blogueiro. 
c) O UOL alterou, no dia da eleição presidencial, o layout de seu canal específico para a cobertura das eleições.

Tabela 3 - Modelo para monitoramento das revistas

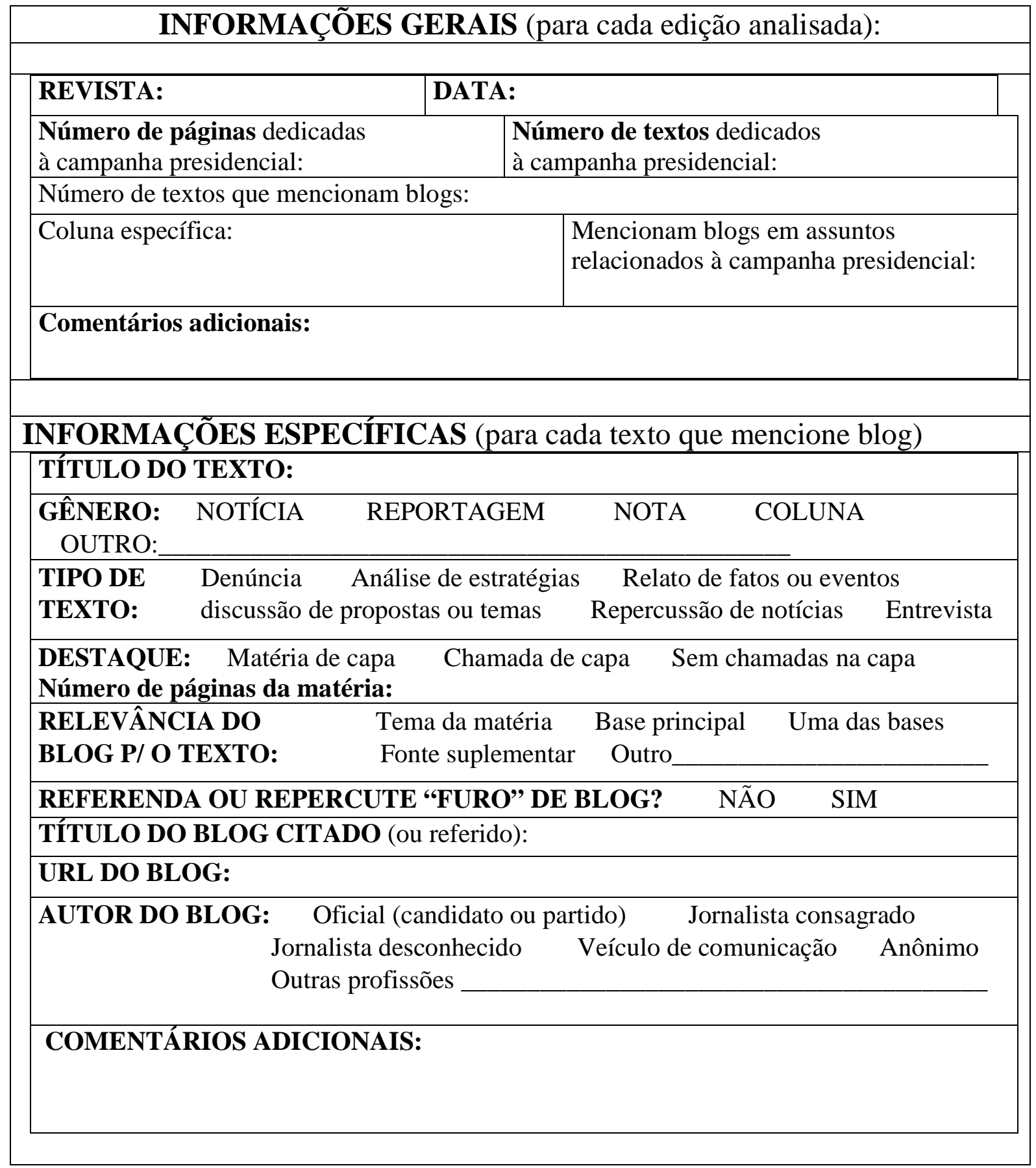


A análise de conteúdo das revistas semanais Veja e Época contemplou nove edições de cada uma delas no período estipulado. Para a sistematização dos dados, foi utilizada uma tabela praticamente igual à da análise dos jornais, mas com algumas alterações (ver Tabela 3). Além das explicações já efetuadas anteriormente, é necessário acrescentar:

a) Número de páginas: dedica-se a registrar a quantidade de espaço destinado à cobertura da campanha para a eleição presidencial. Quando uma página foi dividida entre a campanha presidencial e anúncios ou outros assuntos, optou-se por fracionar a página. Como exemplo, pode-se citar a edição da revista Veja referente ao período de 6 a 11 de agosto, que dedicou uma página e meia à cobertura da campanha presidencial.

b) Coluna específica: assim como ocorreu com os jornais, Veja e Época publicaram durante o período de análise colunas com pequenas notas de bastidores. Na Veja, a seção chamava-se "Radar"; na Época, intitulava-se “Bastidores”.

\subsection{2) A segunda análise de conteúdo}

Um cruzamento dos dados apurados por esta pesquisa com a audiência medida pelo levantamento Ibope/NetRatings em setembro de 2006 levou o pesquisador a escolher os blogs dos jornalistas Fernando Rodrigues ${ }^{15}$ (quarto mais citado pela Folha, segundo mais usado pelo UOL e, com 301 mil visitantes únicos, o dono da maior audiência), Josias de Souza ${ }^{16}$ (mais citado pela Folha, mais

\footnotetext{
${ }^{15} \mathrm{http}$ / / /uolpolitica.blog.uol.com.br/. Acesso em 25 jun. 2007.

16 http://josiasdesouza.folha.blog.uol.com.br/. Acesso em 25 jun. 2007.
} 
usado pelo UOL, dono da segunda maior audiência - 293 mil visitantes únicos) e Ricardo Noblat $^{17}$ (segundo mais citado pelos dois jornais, único a ter furo referendado tanto por Globo quanto por Folha, dono da terceira maior audiência - 83 mil visitantes únicos) e do ex-ministro José Dirceu ${ }^{18}$ (mais citado por Folha e O Globo, mais utilizado pelo IG) para a segunda análise de conteúdo, também qualitativa. Para o corpus dela, os quatro blogs tiveram todos os seus posts pesquisados em dois períodos de uma semana -o primeiro, entre 21 e 27 de agosto, em que não houve nenhum fato excepcional; o segundo, entre 18 e 24 de setembro, quando os veículos de imprensa noticiaram com destaque a suposta participação de Freud Godoy, assessor especial da Presidência da República, em esquema para comprar um dossiê que prejudicaria políticos do partido de oposição ao presidente Luiz Inácio Lula da Silva, que disputava a reeleição.

Para reunir o material necessário, o pesquisador acessou os arquivos dos quatro blogs escolhidos e copiou, manualmente, o conteúdo publicado nos dois períodos para arquivá-lo em documentos do programa Word, da Microsoft. Todos os links inseridos ao longo dos posts foram checados e catalogados. Também foram objeto de análise as áreas de comentários de cada post dos quatro blogs, para a checagem de eventual interação do autor com seu público.

\footnotetext{
${ }^{17}$ http://noblat.estadao.com.br/noblat/index.html. Acesso em 10 out. 2006. À época das eleições, Noblat escrevia para o portal do jornal "O Estado de São Paulo". A partir de $1^{\circ}$ de janeiro de 2007, seu blog passou a ser publicado em "O Globo Online". Em 25 jun. 2007, o novo endereço de seu blog era http: //oglobo.globo.com/pais/noblat/.

${ }^{1818}$ http:// blogdodirceu.blig.ig.com.br/. Acesso em 25 jun. 2007.
} 


\section{3 - Justificativas e delimitações}

\subsection{1 - A escolha da campanha presidencial}

A campanha para a eleição presidencial de 2006 foi escolhida como campo para esta pesquisa por possuir três características essenciais. Primeiro, pela importância do momento político-social. Os veículos de comunicação geralmente concentram seus esforços, realizam investimentos e buscam diferenciar-se da concorrência durante a cobertura da campanha e da votação. Segundo, a eleição tem calendário, com datas definidas, que permitem o planejamento e a definição de prioridades. Pressupondo-se que a cobertura das eleições é um dos momentos em que as empresas mobilizam o máximo de recursos técnicos e informativos, é pertinente analisar o papel dos blogs no jornalismo neste contexto. Terceiro, a disputa pela presidência da República em tese deveria gerar polarização ideológica e debates sobre questões de suma relevância para o país. Durante a campanha, eleitores mais convictos poderiam influenciar outros menos decididos, usando blogs para argumentar e apontar virtudes de um, falhas de outros -e, inclusive, divulgar denúncias contra candidatos. Jornalistas consagrados analisariam em seus blogs instantaneamente eventos relevantes da campanha, mudanças de estratégia e opiniões de especialistas, entre outros. Ou seja, a blogosfera tendia a estar bastante ativa, pulsante, durante a campanha presidencial.

"Quando, daqui a alguns anos, voltarmos a analisar o que foi a eleição presidencial de 2006, talvez o que chamará nossa atenção é o quanto ela foi monótona, quão pouco aconteceu em tantos meses (...)" (COIMBRA, 2007, p. 188) 
Apesar da monotonia do pleito, em que, como afirma o diretor do Instituto Vox Populi, não ocorreram grandes alterações no quadro eleitoral do início oficial da campanha à reeleição do presidente Luiz Inácio Lula da Silva, em segundo turno, com 58.295.042 de votos (60,83\% dos votos válidos), a expectativa do pesquisador ao iniciar o projeto que culmina nesta dissertação confirmou-se, como indicam análises contidas no livro “A mídia nas eleições de 2006”. "Nunca cidadãos comuns escreveram tanto sobre política como no ano de 2006" (SILVEIRA, 2007, p. 181). “A Internet configurou-se como uma forma de mobilização de leitores orgânicos" (COUTINHO, BARROS FILHO e SAFATLE, 2007, p. 99), “viabilizou a atividade dos cibermilitantes em escala nacional, possibilitou a superação de suas limitações de localização, (...) garantiu que pessoas que não são politicamente ativas expressassem mais amplamente suas opiniões" (SILVEIRA, 2007, p. 184).

\subsection{2 - Campanha eleitoral como cenário}

Nos últimos anos, uma série de estudos se dedicaram a investigar como a emergência da Internet, dos meios sociais e dos blogs, em particular, afetam o andamento das campanhas eleitorais e o processo de definiçãa de votos dos eleitores. O uso da rede nas eleições ao Parlamento Europeu em 2004 em diversos países do continente (LUSOLLI, 2005), como Barack Obama usou os meios sociais para formar uma ampla base de ativistas jovens na campanha que o elegeu presidente (RENÓ e ESPERIDIÃO, 2008), Howard Dean e sua revolucionária forma de arrecadar fundos para as eleições de 2004 nos EUA (CRUMLISH, 2004; 
BOWERS e STOLLER, 2005), por exemplo, e mais especificamente sobre a eleição de 2006 no Brasil, o livro de LIMA (2007) e os artigos de BOLAÑO e BRITTOS (2008) e MALINI (2007) foram assunto de trabalhos consultados para esta dissertação, mas fogem do escopo dela: aqui, as eleições são o campo de pesquisa, o pano de fundo escolhido para a observação dos blogs sob o ponto de vista de sua influência no jornalismo e sua suposta capacidade de introduzir novos atores no espaço público. Pelos mesmos motivos, não serão abordados a disputa política em si nem o comportamento da imprensa em relação aos candidatos.

\subsection{3 - Eleições e opções}

A pesquisa limitou-se à cobertura da campanha para as eleições presidenciais. Ou seja, não contemplou as concomitantes disputas por governos estaduais e vagas em Assembléias Legislativas Estaduais, no Senado e na Câmara dos Deputados. A opção justifica-se pela maior abrangência da disputa presidencial, que envolve todo o país, e pela necessidade de estabelecer um recorte que limitasse a quantidade de dados a serem coletados durante o período de análise, que se estendeu por dois meses, entre $1^{\circ}$ de agosto e $1^{\circ}$ de outubro, data da realização do primeiro turno. Ainda que o segundo turno tenha produzido uma polarização ainda maior e o acirramento dos debates no país, para o cumprimento dos objetivos estabelecidos a campanha do primeiro turno mostrouse suficiente. 


\subsection{4 - A cauda longa}

A movimentação regular de música gravada em pedaços de plástico, assim como o lento manuseio humano da maior parte da informação, sob a forma de livros, revistas, jornais e videocassetes, está em via de se transformar na transferência instantânea e barata de dados eletrônicos movendo-se à velocidade da luz. (...) Thomas Jefferson nos legou (...) o direito de consultar um livro de graça. Mas (...) jamais considerou a possibilidade de 20 milhões de pessoas terem acesso eletrônico a uma biblioteca digital, (...) sem nenhum custo (NEGROPONTE, 1995, p.10).

A “irrevogável mudança dos átomos para os bits” de que trata Negroponte está revolucionando o consumo de produtos culturais na sociedade contemporânea. No livro "A cauda longa", de 2006, Chris Anderson explica o conceito que dá nome à obra e é pertinente para que sejam explicadas algumas das características do recorte metodológico necessário para a conclusão deste trabalho: a "cultura dos hits", em que algumas músicas, filmes, seriados ou livros de enorme sucesso garantiam o faturamento de todo um segmento industrial está sendo substituída pela "cultura de nicho" da cauda longa. "Estamos falando da grande maioria de tudo. A maioria dos filmes não é sucesso de bilheteria, a maioria das músicas não alcança as paradas de sucesso, a maioria dos livros não é de best-sellers" (ANDERSON, 2006, p. 6). Como na passagem dos “átomos” para os "bits" (por exemplo, de CDs -que têm de ser gravados em pedaços de plástico, transportados para lojas, onde ficam estocados e onde o espaço de exposição é limitado- para lojas virtuais) eliminam-se “os gargalos que se interpõem entre a oferta e a demanda" (ANDERSON, 2006, p. 11), para a indústria cultural da atualidade é simples, barato e mais lucrativo disponibilizar tudo. Ou seja, além dos sucessos, que serão procurados por um maior número de pessoas, haverá uma 
enorme gama de obras que serão, cada uma, acessadas ou compradas por um pequeno público. Essa enorme gama produz a "cauda longa" a que se refere o autor.

“O estilhaçamento da tendência dominante em zilhões de fragmentos culturais multifacetados é algo que revoluciona em toda a sua extensão os meios de comunicação e a indústria do entretenimento. Depois de décadas de refinamento da capacidade de criar, selecionar e promover grandes sucessos, os hits já não são suficientes. O público está mudando para algo diferente, a proliferação caótica e emaranhada de... Bem, ainda não temos um termo adequado para esses não-hits. Decerto, não são 'fracassos', pois, para começar, a maioria não buscava a dominação mundial. São “tudo o mais'” (ANDERSON, 2006, p. 5).

Parece-nos adequado transpor esse conceito à blogosfera. Um número indeterminado de pessoas usaram blogs para se manifestar sobre a campanha para a eleição presidencial de 2006 no Brasil. Alguns, como os blogueiros alojados nos principais portais ou com vínculos com a imprensa tradicional, obtiveram elevados índices de audiência. A maior parte deles, não -o autor chegou a monitorar, após pesquisas aleatórias, dezenas de blogs que se posicionavam amplamente a favor da reeleição de Lula e outros tantos que pareciam formar uma comunidade contrária ao presidente. Somente um deles ${ }^{19}$, de acordo com a pesquisa Ibope/NetRatings, logrou mais de 5 mil visitantes únicos mensais em agosto ou setembro. A lógica indica que ao menos outras centenas -senão milhares- de pessoas abordaram assuntos relativos à campanha eleitoral em suas páginas, mas não conseguiram repercussão nos veículos de jornalismo analisados e, provavelmente, atraíram público muito pequeno. Nesta dissertação, por uma opção metodológica, optou-se por limitar o escopo ao topo

\footnotetext{
${ }^{19} \mathrm{http}$ ://waltercarrilho.blogspot.com/, atualizado pelo jornalista Walter Carrilho, obteve pouco mais de 6 mil visitantes únicos em setembro, de acordo com o Ibope/NetRatings. Acesso em 17 jun. 2007.
} 
da pirâmide. Ou seja, as especificidades, propriedades e o comportamento de toda essa "cauda longa" de blogueiros que não conseguiram superar a barreira da recepção em larga escala permanecem como interessante objeto de estudo para futuras obras acadêmicas.

\subsection{5 - Jornalismo de texto}

O trabalho versa, em linhas gerais, sobre as relações entre os blogs e o jornalismo praticado por veículos impressos, como os jornais e revistas, e o exercido pelos principais portais nacionais, que, mesmo valendo-se das possibilidades multimídia da Internet, ainda ancoram sua cobertura principalmente no texto. Ou seja, a palavra "imprensa" ou a expressão “jornalismo impresso” não seria adequada por dois motivos: primeiro, “imprensa”, no sentido literal, não contemplaria os portais de Internet, fundamentais ao trabalho; segundo, se por "imprensa" fosse entendido o conjunto de veículos de comunicação, estariam inseridas também as rádios e TVs, que não foram analisadas aqui.

Destas dificuldades surgiu a opção por utilizar o termo "jornalismo de texto", empregado pelo professor Carlos Chaparro, da ECA-USP, em artigo em que defende que o importante para os apreciadores da leitura de jornais é a manutenção do jornalismo de texto, seja nos periódicos tradicionais, seja no novo suporte propiciado pela Internet (CHAPARRO, 2005). Como, de fato, a análise dos veículos informativos restringiu-se aos textos veiculados, a denominação parece adequada. 


\subsection{6 - A ausência de debate sobre definições de jornalismo}

Uma das querelas mais acaloradas relacionadas aos blogs recentemente, entre blogueiros, cidadãos e acadêmicos, é a pertinência ou não de sua configuração como jornalismo. Ainda que os blogs sejam o objeto, e o jornalismo, o campo de conhecimento, a este estudo não interessa abordar definições de jornalismo para discutir que requisitos determinados tipos de blog ou outras formas de participação do cidadão no jornalismo (que serão discutidas no capítulo 3) cumprem, determinando se e aonde poderiam ser encaixados dentro deste campo do conhecimento. Tampouco se pretende proceder ao debate do que caracteriza uma notícia, na tentativa de legitimar (ou retirar legitimidade de) histórias que vêm sendo publicadas por indivíduos com formações profissionais as mais diversas em blogs e sites colaborativos nos últimos anos. Em primeiro lugar, esta opção justifica-se pelo fato de o fenômeno da participação dos usuários na produção de conteúdo na Internet ser muito recente. Por isso, seus usos encontram-se ainda em processo de evolução e, conseqüentemente, ainda em constante mutação. Em segundo lugar, a heterogeneidade de formatos que vêm surgindo e a natureza fragmentária da Internet, que inviabiliza uma observação global de suas diferentes vertentes e desenvolvimentos, tornam, na prática, impossível estabelecer classificações que abarquem a contento a vasta diversidade da rede. Em terceiro lugar, porque independentemente de definir ou não como jornalismo ou como notícia os conteúdos produzidos por cidadãos, fato é que, progressivamente, estes estão a ganhar público e influenciar diferentes setores das sociedades contemporâneas 
sob formatos e suportes de mídia os mais diversos. Sendo assim, este trabalho centra foco na análise, sob diferentes ângulos, do potencial dos blogs para a publicação de conteúdo e o estabelecimento de conversações e comunidades na Internet, bem como as implicações disso para o jornalismo tradicional.

\subsection{7 - Os EUA e o Brasil}

Ao longo de boa parte do trabalho, serão mencionados mecanismos, ferramentas, casos e exemplos para enunciar os potenciais dos blogs. Os desdobramentos enumerados ocorrem principalmente nos EUA, onde foi criada boa parte das ferramentas e onde as características da sociedade facilitam a ocorrência de determinados fenômenos. É preciso esclarecer que o contexto social, econômico, tecnológico e também político de cada país exerce pressão decisiva para a adoção ou não de práticas, o surgimento ou não de oportunidades, e a popularização ou não de dada ferramenta ou tecnologia. Pode-se realizar uma analogia a SINGER (2005, p. 175), que cita que a democratização da Internet não depende da qualidade ou da característica da tecnologia, mas da qualidade das instituições políticas e do caráter dos cidadãos. O mesmo ocorre com os blogs e seus dispositivos auxiliares.

Além disso, o número limitado de institutos a efetivarem pesquisas sobre a Internet e, principalmente, sobre blogs no Brasil, faz com que, muitas vezes, os únicos dados disponíveis sobre um dado assunto sejam estrangeiros. Sempre que possível, foram incluídos exemplos brasileiros. Entretanto, o fato de fenômenos terem se desenrolado no exterior não invalidam, aos olhos deste estudo, a 
análise do potencial de ferramentas que estão disponíveis também para quem vive no país.

\subsection{8 - Os padrões e traduções neste trabalho}

O pesquisador optou por inserir, no corpo do texto, traduções livres de textos que originalmente foram publicados nas línguas inglesa, espanhola e francesa. Ainda que, com esta opção, corra-se o risco de produzir pequenas distorções no que foi escrito pelas fontes referenciadas, desta forma, facilita-se e uniformizase a leitura do trabalho.

A utilização de palavras em inglês, como o próprio objeto deste estudo, o blog, fez-se necessária pela novidade de uma série de termos técnicos de Internet cunhados no exterior, o que implica, por ora, na inexistência de traduções amplamente aceitas ou adotadas no país.

Quanto às referências bibliográficas indiretas e diretas, optou-se por reuni-las na bibliografia final do trabalho. As notas de rodapé foram usadas para explicar alguns termos que não são de uso corrente ou para explicitar os endereços eletrônicos de sites e blogs referidos ao longo do texto. 


\section{Capítulo 2 - Os blogs e suas peculiaridades}

\section{1 - 0 que é blog?}

A palavra "blog” é uma abreviação do termo "weblog”, cunhado pelo norteamericano Jon Barger, que o utilizou pela primeira vez em seu site pessoal, o “Robot Wisdom”, em dezembro de 1997 (ORIHUELA, 2006, p.40). Weblog é a fusão de duas palavras da língua inglesa, “web” e “log”. “Web” significa, literalmente, “teia" ou "rede”. Após o advento da rede mundial de computadores, a palavra “web” passou a ser usada como sinônimo de "World Wide Web" -nome dado ao sistema de documentos interligados sob o qual a Internet opera. “Log”, por sua vez, significa "lenha” e "diário de bordo" (em navios). Além disso, intitula-se “log” o registro de atividades efetuadas em um computador.

A quantidade de significados possíveis que emana da junção literal das duas palavras impõe um pequeno esboço da origem e da evolução dos blogs, para que as definições e acepções da palavra ajustem-se ao contexto histórico e aos usos que gradualmente foram sendo feitos deles.

David Winer, um dos pioneiros na utilização de blogs -sua primeira experiência no gênero data de fevereiro de 1996-, afirma que o primeiro blog foi justamente o primeiro website, criado por Tim Berners-Lee em 1992 (WINER, 2002). Ainda que rudimentar em termos gráficos, a página ${ }^{20}$ continha elementos que permanecem fazendo parte de praticamente qualquer definição de blog pequenos textos e uma série de links correlatos ao tema abordado- e deixa

\footnotetext{
${ }^{20}$ Disponível no endereço: http://www.w3.org/History/19921103-

hypertext/hypertext/WWW/News/9201.HTML. Acesso em 12 jun. 2007.
} 
transparecer algumas das características marcantes do que Orihuela denomina “blogosfera 1.0”, período que abrange de 1992 a agosto de 1999 (ORIHUELA, 2006, p.78): os blogueiros, que até o fim de 1998 não somavam mais de duas dezenas, eram norte-americanos e abordavam essencialmente assuntos relacionados à informática em páginas graficamente simples, que demandavam conhecimentos da linguagem "HTML ${ }^{21 "}$ para sua criação e atualização.

A natureza dos primeiros blogs, basicamente uma relação de links comentados, e o meio a que pertenciam seus criadores torna provável que, em suas origens, o termo weblog significasse algo como "registro de atividades na rede mundial de computadores”, empregando-se, assim, à palavra “log”, o sentido mais utilizado por programadores: registro de ação produzida no computador.

No início de 1999, outro dos blogueiros pioneiros, o norte-americano Cameron Barrett postou em seu weblog, CamWorld ${ }^{22}$, uma lista com as 23 páginas do gênero então conhecidas. A relação fez sucesso: uma espécie de comunidade emergiu em torno destes 23 weblogs e paulatinamente outras pessoas adotaram a idéia de criar suas páginas (BLOOD, 2000).

Para atender a essa demanda, ainda reduzida, mas crescente, nos primeiros meses de 1999 surgiriam as primeiras ferramentas para a criação de blogs. A maior parte dos autores considera a $\operatorname{Pitas}^{23}$, criada em julho de 1999 pelo canadense Andrew Smales, a pioneira. Já ANTÚNEZ (2005, p. 52-53), afirma que

\footnotetext{
${ }^{21}$ HTML é uma sigla para Hypertext Markup Language, linguagem mais utilizada historicamente para criação de páginas na Internet.

22 http://www.camworld.com/journal/rants/99/01/26.html, acessado em 18 jun. 2007.

23 http://pitas.com, acessado em 18 jun. 2007.
} 
a primeira ferramenta foi, na realidade, o LiveJournal ${ }^{24}$, lançada em 18 de março de 1999, por um norte-americano então com 19 anos. O serviço utilizava o termo “journal” em vez de blog, mas já “incluía características próprias de um blog, como a ordem cronológica reversa (...), a possibilidade de outorgar a cada anotação um emoticon ${ }^{25}$ para saber o estado de ânimo do autor, comentários (...)” (ANTÚNEZ, 2005, p. 53). Em agosto do mesmo ano, foi lançado o programa que seria um divisor de águas: o Blogger. Até o fim do ano, quatro outros novos serviços estavam disponíveis nos EUA (BLOOD, 2000).

Em comum, todas estas ferramentas -e muitas outras lançadas posteriormente- têm como características disponibilizar ao usuário a possibilidade de publicar de forma célere páginas pessoais pré-moldadas, que não requerem nenhum conhecimento da linguagem “HTML”. O Blogger apresentava ainda outra vantagem: ao contrário dos outros softwares pioneiros, oferecia a possibilidade de publicação de um blog a partir do preenchimento de apenas um campo de texto a cada entrada (BLOOD, 2000). Ou seja, bastava ao blogueiro escrever e, com um clique, sua mensagem era publicada na Internet, sob um endereço fixo. Com o Blogger, "os usuários do meio deixariam de ser uma pequena família de iniciados e se converteriam em uma grande comunidade transnacional”. (ORIHUELA, 2006, p. 41).

O Blogger entendeu, melhor do que nenhum outro, a psicologia do indivíduo que vive na sociedade da informação. (...) A eficácia da página inicial com slogans na parte superior que motivavam a criação de um blog, a publicação de notícias em torno do

\footnotetext{
${ }^{24}$ http: / /livejournal.com. Acesso em 18 jun. 2007.

25 Emoticons são pequenas figuras de uso corrente na Internet. Nelas, sempre há um rosto humano estilizado, com diversas variações gráficas que buscam reproduzir emoções ou o estado de ânimo de uma pessoa.
} 
emergente fenômeno blog, a lista de últimos atualizados (...) foram decisivos para consolidá-lo como a iniciativa líder (ANTÚNEZ, 2005, p. 57-58).

A partir do segundo semestre de 1999, popularizou-se um dos primeiros usos dos blogs, que permanece em voga na atualidade: o de diário pessoal. Internautas escreviam (e escrevem) sobre eventos de seu cotidiano, idéias, esboços literários. Daí a definição, adotada pela pesquisadora brasileira Denise Schittine, de blog como "diário íntimo na Internet”. (SCHITTINE, 2004, p.12).

A partir do surgimento do Blogger, passou a crescer exponencialmente o número de usuários, a criatividade humana aflorou, e a gama de funções a que se prestam os blogs continua a se expandir. Afinal, os programas proporcionam aos usuários a chance de publicar páginas pessoais a partir simplesmente do preenchimento de espaços em branco. E estes foram e continuam sendo ocupados de formas cada vez mais diversas. Para acompanhar esta evolução, também as ferramentas para a publicação desenvolveram-se, em processos ainda vigentes de mudança e adaptação de necessidades.

Desta forma, a definição "diário íntimo na Internet” paulatinamente tornouse redutiva, deixou de abarcar a diversidade de papéis assumidos pelos blogs.

As referências a 'diário pessoal' são mais próprias de um gênero de weblogs (os autobiográficos) que, ainda que muito difundido, não deve ser confundido com o weblog como meio, em que é possível abordar um variado repertório de âmbitos temáticos (weblogs jornalísticos, corporativos, científicos, educativos, políticos). (ORIHUELA, 2006, p. 36).

Uma vez que os usos diversos impossibilitam a determinação satisfatória do que é um blog por meio de seu conteúdo, como, então, defini-lo? Há elementos formais apontados por diversos teóricos que auxiliam na compreensão dos 
requisitos básicos para a caracterização de um weblog. Abaixo, três esboços de definição, produzidos por quatro autores -uma brasileira, um espanhol e dois americanos:

Websites pessoais baseados nos princípios do microconteúdo e atualização freqüente que possuem uma estrutura comum organizada em função do tempo. (RECUERO, 2003, p. 3).

Site pessoal autogerido composto por entradas individuais que possuem um endereço próprio e data e hora de publicação e estão ordenadas em cronologia inversa (do mais novo para o mais velho). (ORIHUELA, 2006, p. 30).

Weblogs são diários online freqüentemente atualizados, com entradas em ordem inversa cronológica e links numerosos, que proporcionam informações instantâneas sobre a vida de quem escreve, notícias ou um objeto de interesse específico. (BOWMAN e WILLIS, 2003, p. 8).

As três definições abordam elementos básicos do formato: blogs são compostos por entradas (ou posts) ordenadas de forma cronologicamente reversa (do mais recente para o mais antigo) e contêm links para outros blogs e sites tanto nos posts quanto em suas laterais (o que, em inglês, intitula-se blogroll). Por outro lado, as duas primeiras definições limitam os blogs a um autor, e há na Internet um grande número de blogs coletivos, alimentados por duas ou mais pessoas. Há de se acrescentar, ainda, uma outra característica não mencionada, fundamental por estimular o intercâmbio de idéias entre quem escreve e quem lê: em geral, abrigam espaço para comentários de terceiros abaixo de cada post.

Estes pré-requisitos constitutivos serão, assim, utilizados como critérios ao longo desta dissertação para tratar ou não um site como blog -passo metodologicamente necessário, ainda que não seja tarefa muito difícil diferenciar blogs de outros tipos de website. "A oferta de ferramentas 
tecnológicas por parte de empresas que disponibilizam a criação de páginas neste formato -na maioria dos casos gratuitamente- terminou por moldar o termo" (ARAUJO, 2006, p. 41). Ou seja, como a grande maioria dos usuários utiliza serviços de hospedagem de blogs que padronizam as características enumeradas no parágrafo anterior -apesar de praticamente todas concederem algumas possibilidades de diferenciação gráfica e a oferta de dispositivos auxiliares variar significativamente-, acaba sendo automaticamente denominada "blog" toda página publicada por meio destes serviços.

\section{2 - Características e atrativos}

No início de 1999, contavam-se 23 blogs (BLOOD, 2000). No fim de 2002, existiam cerca de 15 mil (BUTTERWORTH, 2006). Quando o site Technorati ${ }^{26}$, referência para busca de blogs e dados referentes a eles, começou a fazer seu levantamento quadrimestral, passaram a existir dados mais precisos. Em outubro de 2003, havia 1 milhão de blogs. Em março de 2004, 2 milhões. Um ano mais tarde, 7,5 milhões. Em outubro de 2005, 19,6 milhões. Em abril de 2007, mais de 70 milhões. E, em junho de 2008, o número de blogs ultrapassava 133 milhões. (MADANSKY e ARENBERG, 2008).

Se é fato que muitos destes blogs são criados e abandonados logo em seguida, o número de posts diários indica intensa atuação blogueira: são cerca de 900 mil novas entradas diariamente no mundo (MADANSKY e ARENBERG, 2008). E a distribuição dos posts pela língua utilizada demonstra que os blogs são um

\footnotetext{
${ }^{26}$ http://technorati.com/, acessado em 13 jun. 2007.
} 
fenômeno mundial: am abril de 2007, 37\% das publicações da blogosfera eram da língua japonesa; 36\% das entradas eram escritas em inglês; $8 \%$, em chinês; 3\% em italiano; $3 \%$ em espanhol; $2 \%$ em português; $2 \%$ em russo; $2 \%$ em francês; $1 \%$ em alemão; 1\% em pársi (SIFRY, 2007).

Para além da morfologia e das noções básicas, faz-se necessária uma análise mais aprofundada de algumas das características que induziram e persistem induzindo tantas pessoas a criarem blogs. Facilidade de publicação, instantaneidade, interatividade -com a possiblidade de formação de comunidades-, valorização da subjetividade, multiplicidade de usos e até questões psicológicas são alguns dos elementos que podem auxiliar a compreensão dos motivos do crescimento exponencial da blogosfera.

\subsection{1 - Publicação fácil e instantânea}

Já foi mencionado que o advento das ferramentas para criação de blogs, na metade de 1999, simplificou um processo antes complicado de publicação na Internet. Convém detalhar essa assertiva.

Antes mesmo de o termo weblog ser cunhado, já existiam na Internet serviços para a publicação de sites pessoais, em que os conteúdos gerados pelo usuário eram armazenados em servidores e disponibilizados sob endereços fixos. Entretanto, havia uma série de restrições. Era necessário conhecer a linguagem HTML, o que por si só já mantinha a grande maioria leiga apartada da atividade. Mesmo para aqueles que dominavam a arte de construir códigos, havia considerável dispêndio de tempo na produção da estrutura e da interface da 
página, e na transferência dos arquivos, de texto e de imagem, do computador do usuário aos servidores do serviço de hospedagem de sites (CAMBRONERO, 2006, p. 13-14). Com as ferramentas para criação de blogs, eliminaram-se, de imediato, duas grandes barreiras à publicação na Internet: uma, técnica, outra, de tempo necessário para produção e atualização dos sites.

Há ainda duas outras inovações, não menos fundamentais, introduzidas pela utilização de blogs: a organização das entradas em ordem cronologicamente inversa, que iça automaticamente ao topo da página a intervenção mais recente do autor, e o arquivamento automático dos posts mais antigos. Nos websites pessoais, quando introduzia um novo conteúdo e queria colocá-lo em sua página inicial, o criador tinha duas opções: substituir o tema anterior pelo mais novo neste caso, ou arquivava o conteúdo antigo ou simplesmente o descartava-; acrescentar um novo item à sua página inicial -em alguns casos, precisando alterar a interface gráfica ou o formato da página. Assim, boa parte dos websites pessoais exibia, constantemente, uma página inicial fixa, mesmo quando havia novas informações em abundância. Os que optavam por manter sua página inicial dinâmica precisavam preocupar-se com o tema e gastar tempo efetuando atualizações, incômodos que o advento dos blogs eliminou.

\subsection{2 - Da interação às comunidades}

(...) diferentes práticas blogueiras surgiram (e continuam a surgir) durante o processo de institucionalização de novos formatos. Essas práticas consistem de rotinas específicas e expectativas relacionadas ao uso dos blogs para lograr objetivos comunicativos; eles levam à formação não somente de redes hipertextuais, mas 
também de redes sociais de densidades diferentes (SCHMIDT, 2007, p. 1420).

Uma das características fundamentais que foi se consolidando a partir da expansão do número de usuários e das tecnologias e dispositivos de Internet, acopladas às ferramentas para criação de blogs, é a possibilidade de interação entre blogueiros, outros blogueiros e visitantes, com a formação de comunidades e o estabelecimento de verdadeiras conversações entre grupos, de interesses semelhantes ou não.

A dinâmica da evolução da blogosfera tornou praxe, em praticamente todos os serviços para a criação de blogs, com o passar dos anos, a existência de um espaço para comentários abaixo de cada post veiculado pelo autor, a ponto de esta possibilidade de interação configurar, hoje, um dos elementos definidores da identidade dos blogs.

“Os comentários são um espaço de diálogo entre o autor do blog e seus leitores, uma fonte de enriquecimento, atualização e contraste das histórias publicadas, um lugar para a polêmica e o debate, e também um espaço para que novos blogueiros comecem a se conhecer". (ORIHUELA, 2006, p.110 e 111)

Por meio dos comentários, os blogueiros obtêm feedbacks dos assuntos que abordaram, recebendo críticas e elogios, verificam a popularidade de suas posições ou proposições e até mesmo se vêem aptos a estimar a quantidade de leitores de seus blogs. "Claramente, weblogs com comentários são substancialmente mais lidos e referenciados" (MISHNE e GLANCE, 2006, p.5).

Em seu estudo, divulgado em 2006, MISHNE e GLANCE submeteram a análise quase 686 mil posts de blogs. Concluíram que o número de palavras escritas em comentários equivalia a $30 \%$ do total das palavras publicadas pelos blogueiros, 
apesar de apenas $15 \%$ da amostragem de posts ter recebido comentários (MISHNE e GLANCE, 2006, p. 5).

Blogueiros mais experientes, cientes das peculiaridades dos mecanismos de funcionamento da conversação na blogosfera, respondem às opiniões mais pertinentes no próprio espaço para comentários e, em uma série de casos, inclusive inserem novos posts para explicar uma posição, rebater críticas ou referendar argumentos deixados por seus visitantes. "Posts comentando sobre posts são um ponto-chave da troca de informações na blogosfera" (DREZNER e FARRELL, 2004, p. 7).

A área de comentários também se transformou em local para que pessoas façam propagandas de seus blogs, quando estes tratam de temas correlatos ao abordado. Após comentar o post, o blogueiro visitante deixa a url ${ }^{27}$ de sua página para atrair eventuais interessados.

Muitos blogueiros desejam uma audiência ampla. A sabedoria convencional sugere que o caminho mais confiável para conquistar tráfego (leitura) se dá por meio de links para outros blogs. (...) Quando um blog dá link para outro, os leitores do primeiro estarão mais propensos a lerem o segundo do que estariam de outra maneira. Se gostarem do que lerem, podem tornar-se leitores regulares do segundo blog. Assim, blogueiros são profundamente interessados em descobrir outros blogs que linkam para eles. (DREZNER e FARRELL, 2004, p. 8)

Os links são outro dos elementos fundamentais para o estabelecimento de conversações na blogosfera. “Dar links para fontes e referências é parte essencial da cultura blogueira, já que precisamente compartilhar links interessantes é uma das razões históricas do surgimento dos blogs" (ORIHUELA, 2006, p. 55). 0

\footnotetext{
${ }^{27}$ Url é uma sigla para Uniform Resource Location. É o endereço eletrônico por meio do qual cada página na Internet pode ser acessada.
} 
pesquisador espanhol, inclusive, declarou em entrevista a um jornalista peruano que a prática de troca de links está presente no que denomina "primeiro mandamento da blogosfera: dê links e serás linkado ${ }^{28 ”}$ (ESPINOSA, 2005). Há duas maneiras de fornecer links para outros sites em um blog. Uma é colocá-los ao longo do texto de uma entrada, como forma de transparência -citando as fontes para os argumentos, informações ou dados- ou de facilitar o aprofundamento do leitor no assunto referido. Outra é uma relação de links, geralmente localizada em uma das laterais da página, para outros blogs -e, mais raramente, para sitesque abordam temas semelhantes ou são apreciados pelo autor. Essa lista de links, que permanece fixa no blog, a menos que o proprietário a altere ou atualize -ao contrário dos links nos posts, que ao passar do tempo acabam transferidos para o arquivo- é conhecida como blogroll. "Blogrolls propiciam excelentes meios para situar interesses e preferências do blogueiro, que tendem a usar seus blogrolls para dar links a outros blogs que compartilham interesses comuns" (DREZNER e FARRELL, 2004, p. 7). Os blogrolls e a troca de links, além de estimularem o aumento de tráfego, têm por conseqüência a facilitação do surgimento de comunidades de interesses específicos. Como observa CAMBRONERO (2006, p. 14), “um leitor que não escreve blogs pertence também à comunidade anotando comentários e participando das conversações sem nenhuma restrição”.

Por meio de links, também, sites de busca especializados em blogs, como o Technorati, o Google Blog Search ${ }^{29}$, o Truth Laid Bear, ou o Blogpulse ${ }^{30}$, por exemplo, permitem que usuários encontrem, por meio da digitação de palavras-

\footnotetext{
${ }^{28}$ No original, em espanhol, “enlaza y serás enlazado".

${ }^{29}$ http://blogsearch.google.com/, acessado em 13 jun. 2007

30 http://www.blogpulse.com/, acessado em 13 jun. 2007
} 
chave, os últimos posts de blogs ou os mais lidos sobre os assuntos que desejam. O Technorati apresenta, ainda, uma excelente funcionalidade para os proprietários de blogs que desejam formar comunidades ou simplesmente saber quem os menciona. Digitando a url de seu blog no campo de busca, encontram uma lista, organizada em ordem cronológica inversa, de blogueiros que fornecem atalho para sua página. Além disso, quando uma url de blog é buscada, o Technorati exibe um número sob o chapéu "authority”, que indica quantos blogs mantêm links fixos para a página pesquisada.

Para a consolidação de comunidades, há portais que reúnem blogs que versam sobre um mesmo tema. No Brasil, não há nenhum exemplo de grande repercussão, mas na Espanha e nos EUA, principalmente, já são numerosos os casos em que um site serve como amálgama de blogueiros que têm os mesmos interesses.

Apesar de que os portais de weblogs possam ser criticados por desempenhar uma função parasitária em suas respectivas blogosferas, é certo que seguramente acabarão cumprindo uma valiosa função de filtros, operando como pontes entre os blogs e usuários não-familiarizados com o mundo dos blogs (ORIHUELA, 2004a).

As conversações e a subseqüente forja de comunidades ganharam plenitude ainda maior a partir da progressiva adaptação de ferramentas e dispositivos de Internet à blogosfera, que buscam suprimir o que EFIMOVA e MOOR (2005, p. 1 e 2) definem como os três principais empecilhos à conversação entre blogs: a natureza fragmentada da blogosfera, a ausência de atalhos bidirecionais que unam entradas correlatas sobre o mesmo assunto e a falta de tecnologias que 
detectem todos os posts que se referem a um só tema. É o caso do RSS, das tags, do trackback e, mais recentemente, dos microblogs, de que o Twitter ${ }^{31}$ é o maior exemplo.

RSS é a sigla para Really Simple Syndication, nome dado a um documento no formato $\mathrm{xml}^{32}$ de fácil distribuição. Por meio da instalação de um software agregador -há uma vasta gama de agregadores gratuitos na Internet- e da adição do endereço de RSS de blogs ou sites que escolher, o internauta recebe em seu computador as notícias assim que elas são publicadas. "Logicamente, isto evita a consulta diária a blogs que não tenham publicado novos posts. Com a sindicação, a pessoa se desliga da obrigação de navegar para chegar à informação. Mais do que isso, ao contrário, é a informação que vem a você”. (CAMBRONERO, 2006, p. 14).

As primeiras versões de RSS foram criadas em 1999 pela Netscape para facilitar a publicação de notícias de sites parceiros no Netscape.com sem necessidade de intervenção humana. Em 2000, David Winer, o blogueiro pioneiro já citado, incorporou tecnologia semelhante à da Netscape ao software de blogs de sua empresa, a Userland. A partir de então, uma série de versões de RSS foi desenvolvida, com especificações diferentes entre si, o que tornou a compatibilidade entre os sistemas um empecilho à sua popularização. Em janeiro de 2003, a Userland, principal desenvolvedora, decidiu congelar as características do produto e, desde então, a versão 2.0.1 não foi mais alterada, o que permitiu sua adoção generalizada pelos usuários (GILL, 2005, p. 2).

\footnotetext{
${ }^{31} \mathrm{http}: / /$ twitter.com/. Acesso em 4 nov. 2008.

32 XML é sigla para Extensible Markup Language, linguagem cada vez mais utilizada na Internet. A proposta de sua criação é facilitar o compartilhamento de dados entre diferentes sistemas de informação.
} 
Nem todos os blogs empregam o RSS, mas a tecnologia é difundida o suficiente para integrar o "pacote-padrão" da maior parte dos serviços de criação de blogs, configurando-se em uma preciosa ferramenta que auxilia e torna tarefa mais breve o acompanhamento dos sites e blogs prediletos de um internauta. Em junho de 2008, 82\% dos blogs ativos captados pela pesquisa do Technorati disponibilizavam RSS (MADANSKY e ARENBERG, 2008).

RSS é o instrumento que está permitindo aos blogs converter-se em uma fonte de informação contínua e acessível a muitos internautas. A partir deles, é possível seguir várias conversações de uma vez e participar de qualquer uma delas sem se perder pela blogosfera. (VARELA, 2005, p. 101).

Um dos dispositivos mais interessantes para o acompanhamento de conversações na Internet é o trackback, fusão das palavras em língua inglesa “track" (seguir uma pista) e "back" (de volta). Criado em agosto de 2002, como parte do serviço de blogs Movable Type ${ }^{33}$ (TROTT, B. e TROTT, M., 2002), trackback é um aviso (enviado de um servidor a outro) que um blogueiro "A" manda a um blogueiro "B" quando publica um post comentando ou referindo-se a um post de “B”. Então, a página de “A” exibirá, em anexo à entrada em questão, usualmente, as primeiras palavras do post de “B”, bem como links e a data em que o aviso foi enviado. Se blogueiros "C" e "D" também comentarem o assunto e enviarem trackbacks a "A", o resumo do que disseram e o link para seus posts correspondentes também serão acrescidos ao post original. Assim, os leitores podem facilmente acompanhar o diálogo ou discussão e têm acesso direto às entradas dos blogs envolvidos. E os blogueiros podem, além de participar da

\footnotetext{
${ }^{33}$ http: //www.movabletype.org/, acessado em 13 jun. de 2007.
} 
troca de idéias, encontrar potenciais parceiros, o que estimula a proliferação de comunidades.

Há, entretanto, uma condição para que isto ocorra: “A”, “B”, “C” e "D” têm de ter o dispositivo de trackback habilitado em seus blogs para que o aviso seja enviado. A pré-condição ganha tom de fator limitante pelo fato de que nem todos os serviços de criação de blogs disponibilizam ferramentas para o uso de trackback. Apesar de haver maneiras de instalá-lo manualmente ${ }^{34}$ em alguns dos softwares que não os trazem como uma utilidade-padrão, sua adoção, principalmente no Brasil, aparentemente está longe de ser generalizada -no mundo, 51\% dos blogs ativos utilizam o dispositivo (MADANSKY e ARENBERG, 2008). Conseqüentemente, o recurso ainda não atingiu seu potencial pleno, já que depende de sua adoção por muitos sites para que tenha valor (TROTT, B. e TROTT, M., 2002).

Outro dispositivo que vem facilitando conversações na blogosfera e que, a exemplo do trackback, poderá ser ainda mais útil no futuro, são as tags ou, em português, etiquetas, rótulos, palavras-chave que se atribui a pedaços de informação, como posts, fotos ou vídeos. A associação de palavras-chave aos códigos de HTML é possível desde 1996 (BROOKS e MONTANEZ, 2006, p. 1), mas a idéia começou a ser associada com freqüência aos blogs a partir de 2003 e 2004. Parte dos serviços de hospedagem disponibilizam, na tela de criação de cada post do blog, um campo para que o usuário digite uma ou mais palavras-chave, que ficarão associadas à entrada. Paralelamente, serviços de busca

\footnotetext{
${ }^{34} \mathrm{Em}$ http://ohad-news.blogspot.com/2006/09/trackback-in-blogger.html (acessado em 14 jun. de 2007), por exemplo, o blogueiro Ohad Gliksman ensina como instalar o trackback no software do serviço de hospedagem Blogger.
} 
especializados em blogs, como o Technorati, por exemplo, reúnem os posts mais recentes e relevantes sobre a tag procurada. Estes sites disponibilizam, também, uma tag cloud, literalmente, “nuvem de rótulos”, em que as palavras-chave mais procuradas recentemente são ordenadas alfabeticamente, com as primeiras da lista (em popularidade) exibidas em caracteres maiores para facilitar sua visualização. Além disso, há sites, como o Del.icio.us ${ }^{35}$, que dão aos usuários a possibilidade de criar suas próprias tags, associando a elas blogs, sites, textos e outros tipos de conteúdo. O Del.icio.us permite que um usuário acesse as tags criadas por outros, permitindo o encontro de pessoas com interesses convergentes.

Assim como o trackback, todavia, o sistema de tags possui fatores limitantes. Como afirmam BROOKS e MONTANEZ (2006, p. 5-6), normalmente, os usuários não podem estabelecer relações entre as tags, ou seja, não é possível juntar automaticamente as tags Tikrit, Basra e Bagdá sob um chapéu Iraque. Além disso, sinônimos, palavras no singular e no plural, conceitos idênticos em línguas distintas e mesmo termos com erros de ortografia são inseridos em categorias diferentes, e blogueiros criam diversas etiquetas para se referirem a um mesmo conceito. Apesar das dificuldades, a pesquisa "State of the Blogosphere", do Technorati, aponta para um indício de relação entre a popularidade dos blogueiros e o uso de tags: da lista dos 100 blogs que mais recebem links no mundo em 2008, de acordo com o site, 71\% adotam tags em seus posts. Dos 500 blogueiros posicionados em seguida entre os mais influentes, 59\% adotam tags,

\footnotetext{
${ }^{35}$ http://del.icio.us/, acessado em 14 jun. de 2007.
} 
contra uma média de $36 \%$ do total de usuários ativos (MADANSKY e ARENBERG, 2008). Outra pesquisa ${ }^{36}$ do Technorati, aponta que o uso de tags tem crescido: em fevereiro de $2007,35 \%$ dos posts analisados estavam munidos de alguma tag em julho de 2005 , a pesquisa registrava a presença em menos de $20 \%$ dos posts.

A quarta das ferramentas que pode auxiliar a formação de comunidades entre blogueiros presta-se, na realidade, a diversos fins. Lançado em outubro de 2006, o Twitter, serviço mais conhecido de microblogging, contava em agosto de 2007 com mais de 1 milhão de usuários espalhados pelo mundo (JAVA et al, 2007). É uma espécie de blog mais ágil, para troca de mensagens curtas -cada post comporta no máximo 140 caracteres-, e pode ser atualizado por telefone celular, instant messaging (o MSN é o exemplo mais famoso), e-mail ou por uma interface na Web. Concebido para facilitar a conversação entre amigos, o Twitter pode ser usado também para troca de informação e distribuição de notícias e links. Entre fevereiro e abril de 2007, 13\% dos posts no Twitter continham links (JAVA et al, 2007, p.8) e vários dos usuários de maior prestígio usavam a ferramenta como mini-versões de seus blogs, para divulgar suas últimas e mais interessantes atualizações (JAVA et al, 2007, p.5).

Ainda que o uso do Twitter como forma de divulgação de blogs seja uma opção viável, e a utilização de tags, trackback e RSS venha crescendo, estes dispositivos provavelmente ainda não contribuem tão decisivamente para a formação de comunidades quanto potencialmente podem. Retomando o conceito do "ciclo de realimentação cumulativo entre a inovação e seu uso", de Castells,

\footnotetext{
${ }^{36}$ http: //technorati.com/weblog/2007/04/328.html, acessado em 18 jun. 2007.
} 
é seguro inferir que, se estes mecanismos não forem adotados de forma generalizada nos próximos anos, algo com características semelhantes ou até mesmo com facilidades e propriedades ainda mais úteis provavelmente emergirá.

\subsection{3 - Identidade, subjetividade, cultura da exposição}

Para além da facilidade de publicação, da celeridade de atualização e das possibilidades de interação e formação de comunidades, estiveram e estão a impulsionar a expansão da blogosfera ainda outras características, tanto dos blogs em si, quanto do pensamento do homem contemporâneo da Revolução da Tecnologia da Informação e da forma como ele se percebe no mundo.

Ao modificar os parâmetros de tempo e espaço em escala inédita (CASTELLS, 1999, p. 467), espalhando seus efeitos em todas as esferas da atividade humana (CASTELLS, 1999, p. 43), as novas tecnologias da informação reforçam o papel da busca da identidade ${ }^{37}$ como fonte básica de significado social (CASTELLS, 1999, p. 41) na era da modernidade líquida, marcada pelo declínio das ideologias, emergência do individualismo e precarização dos laços sociais (BAUMAN, 2001).

"Quando falamos de identidade há, no fundo de nossas mentes, uma tênue imagem de harmonia, lógica, consistência: todas as coisas que parecem - para nosso desespero eterno- faltar tanto e tão abominavelmente ao fluxo de nossa experiência. A busca da identidade é a busca incessante de deter ou tornar mais lento o fluxo, de solidificar o fluido, de dar forma ao disforme. Lutamos para negar (...) a terrível fluidez logo abaixo do fino envoltório da forma. (...) Mas as identidades (...) são mais parecidas com crostas que vez por outra endurecem sobre a lava vulcânica e que se fundem e dissolvem novamente antes de ter tempo de esfriar e

\footnotetext{
${ }^{37}$ Para Castells, identidade é “o processo pelo qual um ator social se reconhece a si próprio e constrói significado, sobretudo, através de um dado atributo cultural ou conjunto de atributos, a ponto de excluir uma referência mais ampla a outras estruturas sociais"2. (CASTELLS, 1999, p. 57-58)
} 
fixar-se. Então, há necessidade de outra tentativa, e mais outra -e isso só é possível se nos aferrarmos desesperadamente a coisas sólidas e tangíveis e, portanto, que prometam ser duradouras (...)" (BAUMAN, 2001, p.97)

Para AUGÉ (2006, apud CUNHA, 2008) a busca frenética pela documentação das experiências cotidianas -como visto neste capítulo, uma das primeiras funções atribuídas aos blogs e, provavelmente, uma das principais razões da expansão da blogosfera- se origina do processo de debilitação das ideologias e obrigações intelectuais com as quais estão vinculadas. Para afirmação de sua identidade, "cada indivíduo pode prover-se com peças soltas para ensamblar sua própria cosmologia e ter a sensação de pensar por si próprio". É neste contexto que emerge uma "cultura da exposição", que encontra na Internet um vasto campo para se proliferar, "na qual ser percebido é tudo" (ANDERSON, 2006, p. 72). A busca por notoriedade e por inserção social é sintoma de uma sociedade fragmentada, de uma época carente de aspirações coletivas e em que os objetivos esfarelam-se tão logo são logrados, como apontam respectivamente PLEDEL (2006, p. 21) e BAUMAN (2001, p. 37).

Por representarem um espaço completamente dominado pelo indivíduo, que determina o assunto, a periodicidade com que escreve, as cores e outros detalhes da interface, os blogs vão de encontro tanto à necessidade de fixação de uma identidade quanto à busca por reconhecimento, alimentando a "cultura da exposição". Justamente por permitir a configuração de um espaço pessoal na Internet, que pode prestar-se a qualquer papel, moldar-se às características e à imagem que alguém queira passar como sua, os blogs se encaixam perfeitamente 
ao cenário de "supermercado de identidades" apontado por BAUMAN (2001, p. 98) como atrativo ao ser humano característico deste século. Ao optar pelo anonimato, por exemplo, um blogueiro pode testar o impacto entre seus pares de uma identidade "recém-comprada", que pretenda ou não adotar. "Os blogs permitem que qualquer eu com qualquer identidade diga o que pensa e que, provavelmente, não diria de outra forma" (RODRIGUES, 2005, p. 149).

Além da busca por status social pode haver também motivações de cunho econômico a aumentar o número de blogueiros. Se é fato que criar um blog não é uma das formas mais fáceis de se ganhar dinheiro, a pesquisa "State of the Blogosphere”, aponta que, em média, o blogueiro norte-americano fatura US\$ 200 anuais, em receitas obtidas primordialmente por anúncios em seus blogs (MADANSKY e ARENBERG, 2008). Mais do que isso, o ganho econômico pode se dar no estabelecimento de um capital simbólico intangível e fundamental na Internet, a reputação, que "pode ser convertida em outras coisas de valor: trabalho, estabilidade, público e ofertas lucrativas de todos os tipos" (ANDERSON, 2006, p. 71).

\subsection{4 - Multiplicidade de usos}

Para abordar a multiplicidade de usos, um dos principais fatores que explicam a expansão da blogosfera, é conveniente recuperar alguns dos conceitos expostos neste capítulo: ao alimentar um blog, o usuário é confrontado com um espaço em branco, que pode preencher da forma que imaginar. Segundos após salvar seu post, seu conteúdo estará na Internet, publicado, logo na abertura da página, 
pronto a receber comentários. A evolução das ferramentas de publicação e dos dispositivos auxiliares à blogosfera, o constante crescimento do número de pessoas envolvidas com blogs e, essencialmente, a enorme diversidade cultural e de interesses do ser humano foi moldando, ao longo dos anos, uma gama tão ampla e distinta de usos que a tentativa de estabelecer uma tipologia é, a cada dia, tarefa mais árdua, principalmente considerado o fato de que não se aborda aqui um fenômeno antigo, com parâmetros definidos, e, sim, um evento recente, em processo de desenvolvimento e consolidação.

Inicialmente, é preciso salientar que, ao contrário da blogosfera 1.0 a que se refere ORIHUELA (2006, p. 78), ao longo dos anos os blogs deixaram de ter seu conteúdo limitado ao texto -ainda que este seja o principal foco deste trabalho e, ao menos por ora, ainda predomine na blogosfera. É possível, em um mesmo blog, veicular textos, vídeos, fotos, áudios e infografia. A tecnologia permite, há alguns anos, a alimentação de blogs via telefone celular. Todas estas possibilidades foram criando, paulatinamente, denominações auxiliares, adjuntas ao termo blog, cujos exemplos mais conhecidos são: os vlogs significam blogs em que se publica vídeos; os moblogs, aqueles atualizados por celular; fotologs, de fotos. Os neologismos são prolíficos: o cantor Ed Motta, por exemplo, chama de “bláudio" seu blog ${ }^{38}$, em que disponibiliza músicas, comenta discos e fala sobre seu cotidiano; nos EUA, estão sendo denominadas "sketchblogs" páginas compostas por desenhos; os blogs que versam sobre a guerra do Iraque são apelidados "warblogs"; "artlogs” são os espaços dedicados a divulgar formas de

\footnotetext{
${ }^{38}$ http://www2.uol.com.br/edmotta/html/por/blaudio.html, acessado em 14 jun. de 2007.
} 
arte; "blogonovelas", um novo gênero literário baseado tanto nos blogs quanto em elementos da vida real.

Se a separação dos blogs por formato de mídia que utilizam é simples e pouco passível de discussão, os teóricos que ousam apontar categorias para classificar blogs de acordo com seu conteúdo, invariavelmente, não logram englobar por completo a diversidade da blogosfera. RECUERO (2003) dividiu-os em cinco categorias: weblogs diários (relatam a vida cotidiana do autor), weblogs publicações (buscam trazer informações de modo opinativo), weblogs literários (conjunto de histórias, crônicas ou poesias), weblogs clippings (destinam-se a fazer recortes de outras publicações, sem emissão de opiniões) e weblogs mistos (misturam informações com a vida pessoal do autor). Esta classificação, esboçada em 2003, configura-se, hoje, insuficiente: em que categorias seriam encaixados, por exemplo, os blogs de empresas (ou corporativos)? E os blogs voltados à educação (apelidados de edublogs)? ORIHUELA (2006), por sua vez, cita brevemente seis âmbitos temáticos: weblogs jornalísticos, corporativos, científicos, educativos, políticos e pessoais, ainda que opte por não estender esta tipologia, que não contempla blogs gastronômicos ou de viagem, por exemplo, além da introdução de seu livro.

Em vez de tentar esboçar uma categorização que dificilmente configuraria uma classificação eficaz e estaria desde logo condenada à obsolescência dado o ritmo de evolução da blogosfera, opta-se, aqui, pela enumeração de alguns exemplos variados para deixar clara a amplitude temática do assunto e, em seguida, serão comentadas as áreas mais afetadas por seu advento. TERRA (2006, 
p. 123) cita o caso do English $\mathrm{Cut}^{39}$, alfaiataria de Londres que explica como fazer bons ternos, cita especificações de tecidos, entre outras coisas. O blog teria multiplicado as vendas da empresa. 0 espanhol "Bebés y más ${ }^{40 "}$, de autoria coletiva, aborda a gravidez e aspectos da saúde de bebês. 0 “Gibiblog ${ }^{41}$ ”, por sua vez, fala sobre histórias em quadrinhos, comentando lançamentos e exibindo

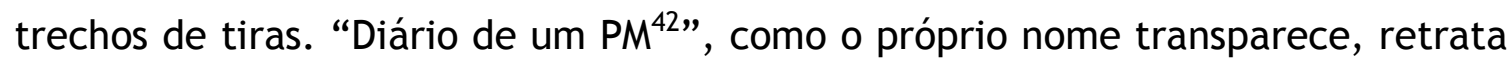
o cotidiano de um policial carioca e trata de assuntos relacionados à segurança pública. Até junho de 2007, o autor, anônimo, mantinha uma contagem do número de policiais mortos em serviço no Estado do Rio de Janeiro. “Arquitetura e tal ${ }^{43}$, , alimentado por uma estudante de arquitetura e urbanismo, se autointitula um espaço para a discussão do tema. O “Chavecando ${ }^{44 "}$ se diz uma “enciclopédia” sobre técnicas de flerte e conquista de mulheres. O blog do webdesigner Tiago Dória ${ }^{45}$ aborda inovações tecnológicas e fornece explicações sobre conceitos de difícil compreensão para leigos, além de antecipar novidades e lançamentos na área. A ex-prostituta Raquel Pacheco, a "Bruna Surfistinha”, lançou um livro e tornou-se figura freqüente em programas de TV após a fama adquirida por seu blog ${ }^{46}$, em que relatava as experiências sexuais com seus clientes. E, para encerrar a lista de exemplos, alunos que participaram da ocupação da Reitoria da Universidade de São Paulo, em maio de 2007,

\footnotetext{
${ }^{39}$ http: //www.englishcut.com/, acessado em 14 jun. de 2007.

${ }^{40}$ http://www.bebesymas.com/, acessado em 14 jun. de 2007.

${ }^{41} \mathrm{http}$ ///www.gibiblog.blogger.com.br/, acessado em 14 jun. de 2007.

42 http: / / www.diariodeumpm.net/, acessado em 14 jun. de 2007.

${ }^{43}$ http: / /arquiteturaetal.blogspot.com/, acessado em 14 jun. de 2007.

44 http: //chavecando.wordpress.com/, acessado em 14 jun. de 2007.

${ }^{45}$ http: / / www.tiagodoria.com/, acessado em 14 jun. 2007.

46 http://www.brunasurfistinha.com/blogs/. Acesso em 15 jul. 2006.
} 
alimentaram várias vezes ao dia um blog ${ }^{47}$ com textos, manifestos, fotos e vídeos do movimento.

ORIHUELA (2006) destaca quatro áreas em que o impacto dos blogs teria sido maior: mundo corporativo, educação, política e jornalismo. Já RODRIGUES (2005) analisa, além destes quatro campos, também a cultura. Como o jornalismo será tema de discussões mais aprofundadas neste trabalho, convém destacar na seqüência as principais perspectivas que a evolução da blogosfera criou para as empresas, a educação, a cultura e a política.

No campo da educação, há iniciativas utilizando blogs ao menos desde 2001, quando o portal britânico Schoolblogs.com, hoje desativado, foi lançado (LARA, 2005). Assim como outros tipos de blogs, os educacionais se multiplicaram nos últimos anos, e os exemplos de uso são diversos. A Universidade do Minho, em Portugal, tem um blog ${ }^{48}$ para os alunos de seu curso de jornalismo. Nele, há indicações de bibliografia, anúncios oficiais, avisos, links comentados para notícias e fatos relevantes à área. Em Parma (Itália), os alunos de quarta série da escola Pilo Albertelli foram instados a construir um blog sobre Harry Potter ${ }^{49}$ para comentar o filme e responder a questões propostas pelos professores (OLIVEIRA, 2005, p. 4). Na Alaska State University, nos EUA, o uso da interface é aplicada a um curso de desenvolvimento da escrita (OLIVEIRA, 2005, p. 4).

“Tanto a educação como os blogs partilham uma característica fundamental: ambos os conceitos podem definir-se como processos de construção do conhecimento" (LARA, 2005). Ao colocar a criação de blogs pelos alunos e passar

\footnotetext{
${ }^{47}$ http: / /ocupacaousp.noblogs.org/, acessado em 14 jun. de 2007.

48 http: / / www.aulajornalismo.blogspot.com/

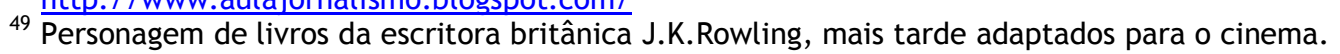


tarefas a serem cumpridas neste espaço, os professores estimulam o autoconhecimento proveniente da escrita e o exercício da argumentação nos comentários (MANCINI, 2005), além de generalizar o uso e a familiarização da criança ou jovem com a Internet e suas formas de pesquisa. Fazer com que os alunos respondam aos comentários os leva a relerem o que escreveram. Assim, a reflexão e o aprendizado também são incentivados (HUANN, 2005, p.2-3). Aos poucos, amostras da escrita de cada um se acumulam, o que pode facilitar a detecção de eventuais erros recorrentes.

O papel da comunicação não presencial proporcionada através do blog pode incentivar aqueles que se sentem mais à vontade em transmitir a sua posição através da escrita, até porque às vezes é difícil promover a intervenção e participação oral dos alunos nas aulas. (...) Trata-se aqui de uma relação entre a blogosfera e a via do ensino que tem funcionado no que diz respeito, por exemplo, a uma maior informação e troca de conhecimento entre professores e alunos. Os blogs apresentam-se como uma forma de apoio às aulas, incentivando a colaboração e a interactividade entre professores e estudantes (RODRIGUES, 2005, p. 114).

Além da produção de blogs por alunos, professores podem criá-los para trocar experiências com outros docentes, expondo idéias e métodos de ensino que obtiveram bons resultados, discutindo bibliografia, por exemplo. “Dispor de um espaço digital comum (...) poupa o esforço individual, reconhece e melhora materiais alheios, abre esferas de discussão e colaboração, assim como mantém mais atualizado quem se integrar nessa rede” (LARA, 2008). Outra opção é a criação de um só blog para uma classe de alunos, ato que pode ter as seguintes utilidades: reunir e organizar links sobre assuntos vinculados à aula e anotações para destacar sua relevância, postar instruções para tarefas, mostrar trabalhos de estudantes, colocar fotos e comentários das atividades de classe, comunicar- 
se com os pais ou unir a aula à de outra classe de algum lugar do mundo (DAVIS, 2004).

No universo das corporações, há, basicamente, dois tipos diferentes de blogs: os internos, ou seja, voltados aos funcionários da empresa, e os externos, que têm como alvo o público em geral, os potenciais consumidores ou clientes (TERRA, 2006, p. 117). A função de ferramenta auxiliar à construção do conhecimento, que tem impulsionado o uso de blogs na educação, é também uma das razões de sua adoção por empresas, que aproveitam a facilidade e a inexistência de custos para sua instalação, e a possibilidade de comentários para que funcionários que desenvolvem um projeto colaborem entre si e recebam idéias de outros integrantes da empresa (blogs internos) ou mesmo do público (blogs externos). Internamente, blogs de gestores podem facilmente comunicar pontos de vista e explicar novos posicionamentos e políticas da empresa, servindo como uma espécie de local para que integrantes do corpo decisório exerçam liderança sobre os funcionários, além de representarem oportunidades para que pontos de vista diversos venham à tona e sejam debatidos. Por outro lado, blogs também podem servir para a implantação de uma ouvidoria interna. “Os blogs internos são geralmente referidos como ferramentas para a colaboração e gestão do conhecimento" (TERRA, 2006, p. 119). Em um exemplo de uso interno, o presidente executivo do HSBC no Brasil -e mais tarde nomeado presidente do banco para a América Latina-, Emilson Alonso, criou o “Blog do CEO”, como ficou conhecido o espaço restrito aos funcionários ${ }^{50}$, que é

\footnotetext{
${ }^{50}$ Ao menos até junho de 2007, apenas funcionários da empresa podiam acessar o blog.
} 
considerado o primeiro blog de um presidente de uma grande empresa no país ${ }^{51}$. Ainda em sua primeira semana (abril de 2006), o local recebeu 13 mil acessos e 398 comentários apenas nos centros administrativos, sem contar as agências bancárias, que também têm acesso ao blog (TERRA, 2006, p. 120).

Apesar das vantagens do uso interno, é na abertura de blogs voltados ao público que reside o maior impacto da ferramenta para as empresas. De acordo com ORIHUELA (2006, p. 163-164), os blogs de uso externo aportam proximidade para com o público (proporcionando uma voz e um rosto pessoal à empresa), ampliam as oportunidades de recebimento de opiniões, reclamações e críticas diretamente dos usuários, sem intermediações -o que possibilita às empresas novas formas de perceber como o público as avalia-, aumentam sua visibilidade (um blog atualizado regularmente, focado e bem escrito tem muito mais possibilidades de receber links do que qualquer site corporativo, com o que se melhora a visibilidade da empresa e de suas marcas ante os meios e as ferramentas de busca) e são instrumentos práticos e ágeis para manter o site da corporação atualizado. Já Terra (2006, p. 118) aponta que “os benefícios incluem fortalecimento das relações com importantes grupos de pessoas e o posicionamento da organização como especialista em determinados assuntos". Os blogs são, também, meios de aumentar a transparência das corporações.

Os blogs, como nenhuma outra ferramenta de comunicação tradicional, dão às organizações a oportunidade de acercar-se de suas audiências, de exibir sua intimidade ante milhões de olhos em todo o mundo, de estabelecer verdadeiras conversações com os usuários e detratores em situações de igualdade. (...) Se trata de

\footnotetext{
${ }^{51}$ De acordo com reportagem veiculada na segunda edição de abril de 2007 da Revista Época, disponível em http://epocanegocios.globo.com/Revista/Epocanegocios/0,,EDG76944-8378-2,00.html. Acesso em 18 jun. 2007.
} 
construir uma ponte entre a organização e sua audiência. Um blog pode fazê-lo de forma lenta, mas sólida (ROJAS, 2005, p. 234-237).

Se no Brasil, por ora, ainda não há muitos exemplos de blogs adotados nas maiores corporações, nos EUA, 34\% das grandes empresas já utilizavam a ferramenta em julho de 2006 e outros 35\% pretendiam implementá-la até o final daquele $a n 0^{52}$. Uma das primeiras empresas a adotar blogs de funcionários e publicar, também um espaço do presidente da empresa, Jonathan Schwartz ${ }^{53}$, é a Sun Microsystems, que desenvolve softwares. "Schwartz insiste (...) que a estratégia serviu para a empresa obter mais clientes, entre outras coisas porque estes conhecem melhor o produto, seus preços e podem transmitir a outros, eficazmente, o que é mais importante para a empresa: suas inovações" (VARELA, 2005, p. 241). Bob Lutz, vice-presidente da General Motors ${ }^{54}$ e Randy Baseler, vice-presidente da Boeing ${ }^{55}$ são outros exemplos de executivos em cargos de comando que alimentam blogs.

$\mathrm{Na}$ área de produtos culturais, que engloba música, literatura, cinema e outras formas de manifestação, como as histórias em quadrinhos, por exemplo, artistas enxergam os blogs como um instrumento a ser utilizado tanto como laboratório em que é possível checar a reação do público a aspectos do trabalho em desenvolvimento quanto como canal para a divulgação de sua produção. "Autores que vêem difícil a publicação de obras através das editoras acabam por

\footnotetext{
52 Pesquisa da consultoria Jupiter Research, divulgada pela revista "IstoÉ Negócios" de 9 ago. 2006, disponível em http://www.terra.com.br/istoedinheiro/464/ecommerce/navegar_nos_blogs_e_preciso.htm. Acesso em 18 jun. 2007.

${ }^{53}$ http: //blogs.sun.com/jonathan, acessado em 18 jun. 2007.

$54 \mathrm{http://fastlane.gmblogs.com,} \mathrm{acessado} \mathrm{em} 18$ jun. 2007.

55 http: //boeingblogs.com/randy, acessado em 18 jun. 2007.
} 
fazê-lo nos blogs, dando assim a conhecer o seu trabalho ao público" (RODRIGUES, 2005, p. 131).

A Amazon ${ }^{56}$, maior livraria online do mundo, criou, em novembro de 2005, um projeto que disponibiliza blogs gratuitos para autores com ao menos um livro à venda em seu website (RODRIGUES, 2005, pg. 133). São espaços em que os escritores podem aproveitar-se do ambiente online da livraria (e do tráfego de pessoas interessadas em leitura) para comentar suas obras, ou disponibilizar trechos de livros inacabados para receberem feedback do público.

Em uma outra espécie de modalidade de blogs ligados à cultura, como os MP3 blogs a que se refere O’DONNEL (2006), internautas apaixonados por música comentam sobre bandas desconhecidas, comparando seu estilo aos de artistas consagrados. Muitas vezes, são disponibilizadas duas ou três músicas do grupo para download e endereço do site para que os interessados possam obter mais informações (O’DONNEL, 2006, p. 7). “Os blogs têm de receber crédito ao menos parcial pelo sucesso de bandas como Franz Ferdinand e Arctic Monkeys, entre outros" (O’DONNEL, 2006, p. 26).

Há, ainda, formas de uso mais criativo dos blogs, com a introdução de gêneros não existentes em outras mídias. É o caso da "blogonovela", termo usado pelo argentino Hernán Casciari, ele mesmo um autor do gênero, para designar "uma história produzida em capítulos, narrados em primeira pessoa, (...), com uma trama que ocorre em tempo real, (...) em que a realidade afeta o desenrolar dos acontecimentos" (CASCIARI, 2005). Nela, os leitores podem conversar com os

\footnotetext{
${ }^{56}$ http://www.amazon.com/. Acesso em 23 jun.2007.
} 
personagens, e notícias e eventos que ocorrem no mundo afetam o andamento da história. Ainda que o termo blogonovela tenha sido cunhado para definir esse gênero que mistura elementos folhetinescos com recursos dos blogs, há, sob o mesmo nome, iniciativas, como a brasileira "A casa caiu" ${ }^{57 "}$ que, com um misto de texto e vídeo, apresentou uma história em 30 episódios, cada um deles postado em um dia diferente.

Na política, para ORIHUELA (2006, p. 183) os blogs dividem-se em dois grandes grupos: os de opinião política e/ou de ativismo e os blogs de políticos. Como está relatado no capítulo 3, blogs de cidadãos (realizando denúncias, ou utilizando conhecimentos específicos de sua área de atuação para desmentir alegações de políticos, entre outras possibilidades) já geraram alguns fatos políticos, principalmente nos EUA. No Brasil, durante a campanha para as eleições de 2006, muitos cidadãos utilizaram blogs "para construir discursos e contradiscursos sobre os fatos e candidatos, bem como para disseminar ataques ou defesas das versões dos embates eleitorais publicados na grande imprensa" (SILVEIRA, 2007, p. 177). A articulação dos blogs com o Orkut $^{58}$ e outras ferramentas da Internet, como o You Tube e listas de discussão, permitiu intensos debates na "disputa de produção de sentidos em torno dos assuntos eleitorais" (HERKENHOFF e MALINI, 2008, p.2). SILVEIRA concorda:

"A importância dos blogs cresce para além de seu número de leitores diretos se considerarmos que eles foram utilizados como uma espécie de munição no interior de chats, de listas e do Orkut. (...) Blogueiros de destaque tiveram seus argumentos reproduzidos ou seus textos postados em scraps (termo utilizado no Orkut para se referir a recados deixados para outra pessoa), fixados em murais

\footnotetext{
${ }^{57} \mathrm{http}: / /$ www.acasacaiu.com.br/, acessado em 18 jun. 2007.

58 http://www.orkut.com. Acesso em 12 nov. 2008.
} 
virtuais e enviados por e-mail para milhares de pessoas" (SILVEIRA, 2008, p. 180).

Para os políticos, por sua vez, criar blog para as campanhas se transformou praticamente em uma lei não-escrita, principalmente depois que o pré-candidato democrata Howard Dean obteve US\$ 7,4 mi dos US\$ 14,8 mi que arrecadou em 2003, um ano antes das eleições de 2004, por meio de seu blog (BOWERS e STOLLER, 2005). Em Portugal, “até o fim de 2004, políticos portugueses praticamente ignoravam a blogosfera. Com algumas exceções, só se voltaram à importância após a imprensa passar a fazer uso e referências. Nas eleições de janeiro de 2006, todos os candidatos tinham blogs oficiais, e a imprensa reproduzia diariamente trechos deles" (CANAVILHAS, 2006, p. 3). Na eleição presidencial de 2006, no Brasil, os principais candidatos também criaram blogs. Entretanto, a falta de adequação da linguagem ao meio levou nenhum deles a fazer grande sucesso, mesmo entre seus simpatizantes. "Os políticos transladam a seus blogs os discursos e artigos que escrevem. (...) São novos formatos para velhas práticas. (...) Resultado: são blogs enfadonhos para a maior parte da população” (FREIRE, apud ORIHUELA, 2006, p. 182).

Os blogs de políticos poderiam se aproveitar do que LE BART (2005, apud JERECZEK-LIPINSKA, 2007) aponta como “culto da proximidade" -trata-se de fazer com que instituições e pessoas poderosas desçam do pedestal, apagando o aspecto inacessível e arrogante. “Nos blogs de políticos, há mais uma oportunidade de aproximação e de colocação de um lado pessoal do autor do que um espaço para que se argumente logicamente ou se explicite propostas de governo. (...) Em resumo, o discurso dos blogs é direto e sem cerimônias, é um 
estilo pessoal através do qual transparecem a sensibilidade, o ponto de vista e a personalidade do político" (JERECZEK-LIPINSKA, 2007, p. 164-169).

Além das campanhas, alguns políticos mantêm blogs fora do período eleitoral. No Brasil, o exemplo mais conhecido é o do ex-ministro José Dirceu, que usa seu espaço para manter suas opiniões em alguma evidência após ter tido seus direitos políticos cassados. Na França, os políticos Jack Lang, Alain Juppé e Dominique Strauss Khan têm blogs (PLEDEL, 2006, p. 13), assim como a candidata derrotada na eleição presidencial de 2007 Ségolène Royal ${ }^{59}$.

\section{3 - Audiência e visibilidade}

Nunca tantas pessoas escreveram tanto para ser lido por tão poucos (HAFNER, 2004).

Um dos principais efeitos do advento e desenvolvimento da Internet é a expansão da oferta de informações. Inúmeras páginas são adicionadas à rede mundial de computadores diariamente. Os blogs, que tornaram ainda mais fácil a construção de espaços pessoais online, contribuem para esta multiplicação de endereços no ciberespaço. “À medida que cresce a quantidade dos publicadores e das publicações, decresce a possibilidade de que uns e outros sejam lidos" (SERRA, 2003a, p. 91). Os blogs permitem que cada pessoa com acesso à Internet publique o que pretender, sem filtros, na rede. Mas ninguém será capaz de ler tudo, ou seja, “publicar não é, obviamente, sinónimo de ser visto ou ouvido. (...) Recorrendo à imagem da 'caixa negra', diremos que o que é condicionado,

${ }^{59}$ http://www.segoleneroyal2007.net/. Acesso em 12 nov.2008. 
agora, são não as 'entradas' - tudo e todos podem 'entrar' - mas as 'saídas'” (SERRA, 2003b, p. 77).

De acordo com SERRA $\left(2003^{a}\right.$, p. 85), há duas formas principais para que sejam superados os obstáculos à recepção na Internet: uma, a de que pessoas famosas ou conhecidas e organizações consolidadas -notadamente as empresas noticiosas, dotadas de recursos técnicos, humanos e financeiros adequados- no “mundo real” tenham seu prestígio transposto ao ciberespaço; a outra, conseguir ser referenciado nos sistemas de busca, cujo principal expoente é o Google ${ }^{60}$.

Qualquer um que deseje atenção ou publicidade pode lutar por isso, embora possa não conseguir. O campo de jogo não é nivelado, já que as velhas elites da antiga mídia ainda têm extraordinárias vantagens herdadas, assim como todas as aristocracias em campo em uma época revolucionária. (...) Agora, mesmo que o campo de jogo não seja justo, pelo menos os portões estão abertos para qualquer um que queira jogar (HEWITT, 2005, p. 102-103).

Como as organizações noticiosas tradicionais em geral obtêm êxito ao transferir à Internet as credenciais obtidas offline, superando assim a barreira da recepção para obter audiência e relevância na rede, para RODRIGUES, a blogosfera acaba dependente destas organizações de mídia para atingir uma audiência maciça. "Os blogs permitem criar uma verdadeira esfera de visibilidade pública. Porém, essa situação parece só se concretizar quando existe uma espécie de feedback nos media tradicionais, mesmo quando alguns já conseguiram uma autonomia, visibilidade e até credibilidade próprias" (RODRIGUES, 2005, p. 66-67). AMARAL (2006) concorda, pontuando que a legitimação dos blogs “só acontece por via da representação que os media fazem

${ }^{60}$ http://www.google.com/, acessado em 18 jun.2007. 
deles. A esfera de visibilidade pública é significativamente mais reduzida do que o universo da blogosfera".

Além da dependência dos meios de comunicações tradicionais e dos sistemas de busca, há outro fator que, em tese, contribuiria para tornar o acesso à audiência mais difícil para um cidadão comum, desprovido de credenciais que o tornem conhecido do público em geral. Para explicar a distribuição de links entre os blogs, ao analisarem-nos como redes sociais, alguns teóricos (BENKLER, 2006; MARLOW, 2004; SHIRKY, 2003a) vêm adotando o conceito físico-matemático de distribuição "power law", que RECUERO (2005, p. 8) define como "uma curva logarítmica que decresce abruptamente a níveis próximos de um mínimo e mantém-se assim, construindo uma 'longa cauda', e foi descrito por BARABÁSs ${ }^{61}$ como resultado de um processo de conexões a redes auto-organizadas, "em que os nós mais conectados tendem a receber mais ligações do que os menos conectados" (MARLOW, 2004, p.2). Pela distribuição "power law”, os blogs mais conhecidos tendem a receber um número maior de links, angariando uma audiência cada vez maior.

Existem algumas evidências de que os novos blogs e fotologs procuram conectar-se a blogs e fotologs "famosos", no sentido de aumentar suas chances de receber comentários e interagir socialmente. Isso tem uma relação intrínseca com a necessidade de visibilidade na Internet. As conexões não são feitas de modo aleatório (...): elas são feitas de modo intencional. As pessoas escolhem a quem desejam se conectar, levando em conta valores específicos (tais como o capital social de um determinado grupo ou mesmo indivíduo). Portanto, os nós não têm a mesma chance de receber comentários e links: não se trata de uma rede igualitária (RECUERO, 2005, p. 17).

\footnotetext{
${ }^{61}$ BARABÁSI, A.L. (2002) apud MARLOW, C. Audience, structure and authority in the weblog community. MIT Media Laboratory, 2004.
} 
Três levantamentos realizados nos EUA nesta década obtiveram como resultado uma divisão de links ou de audiência entre blogs que obedece à lógica da distribuição “power law”. Baseando-se em levantamento do site Truth Laid Bear, SHIRKY (2003a) procedeu a uma análise dos 433 blogs que eram alvo do maior número de links em 2002. Os 12 blogs (3\% do total) mais referendados por seus pares recebiam $20 \%$ do número total de links; os 50 maiores (menos de $12 \%$ do universo analisado) acumulavam $50 \%$ das ligações efetuadas. Dividindo-se o número total de links pelo número de blogs, chegava-se a uma média de 31 links recebidos por cada blog; os 141 primeiros colocados obtiveram número superior ou igual a 31, ou seja, dois de cada três blogs eram destinatários de menos atalhos do que a média geral. Em julho de 2003, no universo dos 100 blogs de maior audiência, o número agregado de páginas vistas dos seis primeiros colocados no ranking era aproximadamente o mesmo da soma das páginas acessadas nos 93 blogs restantes (BOWERS e STOLLER, 2005, p. 6). Em 2005, BOWERS e STOLLER definiram uma lista de 1.000 blogs políticos, baseados em dados do site Truth Laid Bear, e os dividiram entre conservadores (alinhados ao Partido Republicano norte-americano) e progressistas (simpáticos ao Partido Democrata). Os autores concluíram que os dez principais blogs conservadores concentravam 54,6\% da audiência total deste nicho, e os dez maiores blogs progressistas amealhavam $69 \%$ do tráfego por blogs enquadrados nesta categoria (BOWERS e STOLLER, 2005, p. 8).

Alguns estudiosos, entretanto, pregam que a distribuição "power law” é, na realidade, uma dinâmica que permite a emergência eventual de anônimos para 
uma audiência considerável. Para BENKLER (2006, p. 241-246), os blogs já estabelecidos, que recebem um número maior de links, visibilidade e importância, acabam servindo como filtros para os demais integrantes de uma comunidade. Por meio de processos interativos de cooperação, filtragem e transmissão pelos nós mais visíveis da rede, até mesmo os blogs menos conhecidos conseguiriam ganhar expressão. DREZNER e FARRELL (2004, p. 12-13) vêem neste sistema uma conveniência tanto para o leitor, que não tem tempo para pesquisar todos os blogs, quanto para os blogueiros, donos de audiência grande ou pequena.

Quando blogueiros menos proeminentes têm informações ou pontos de vista relevantes (...), contatam blogs maiores para dar publicidade a seu post. Estes podem publicar uma entrada referindo-se ao post, fornecendo link para o blog original se a história for interessante o suficiente, aumentando a audiência de quem publicou a informação. Desta maneira, os blogueiros menos famosos funcionariam como 'alarmes de incêndio' para os principais blogs, facilitando também o trabalho destes, que não precisariam percorrer toda a blogosfera para obter informações relevantes (DREZNER e FARRELL, 2004, p. 13).

DREZNER e FARRELL (2004) e BENKLER (2006) defendem que a dinâmica acima exposta tende a um balanço favorável a todas as partes envolvidas. Já SHIRKY (2003a) observa que o sistema, baseado na distribuição “power law”, ou seja, com os ricos (em audiência) tornando-se mais ricos, tende, com o tempo, a criar desequilíbrios.

A transformação (...) é simples: à medida que a audiência de uma blogueira cresce muito, mais pessoas lêem seu trabalho do que ela pode dar conta. Ela não consegue dar links para todos que querem sua atenção, não consegue responder a todos os e-mails ou acompanhar todos os comentários que recebe em seu blog. 0 resultado é que ela passará a distribuir material sem participar de todas as conversações sobre ele (SHIRKY, 2003a). 
Em outras palavras, os maiores blogs passariam a configurar uma espécie de nova grande mídia, que dispõe de grande visibilidade, mas não consegue interagir com seu público crescente. A julgar pelos dados do estudo "State of the live web" divulgado em abril de $2007^{62}$ pelo Technorati, ao menos em termos de ponto de referência para os blogueiros, alguns blogs já são mais importantes que muitos veículos da mídia tradicional. Dos 100 sites mais citados em blogs do mundo no quarto trimestre de 2006, 22 eram blogs -contra 12 no terceiro trimestre do mesmo ano. Nesta relação, constam o blog iraniano TodayLink.ir e as páginas online do jornal espanhol El País e do diário italiano Corriere dela Sera, mas não há sites brasileiros.

A dificuldade que a maior parte dos blogueiros tem de aceder a grandes públicos, entretanto, não diminui a força coletiva dos blogs, defende HEWITT (2005), utilizando o conceito de “cauda longa” cunhado por ANDERSON (2006). “Os blogs de tráfego pequeno ou moderado ocupam um nicho semelhante ao do informativo da associação de pais e mestres, do boletim da igreja e talvez do jornal local gratuito que cobre os esportes colegiais" (2005, p. 144). O autor cita o que denomina "poder da cauda" ${ }^{63 "}$ para explicitar seu ponto de vista.

“'O poder da cauda' é o número agregado de visitantes, não de um blog específico da cauda, mas coletivamente de todos os blogs da cauda, e o fato de que esses blogs de pequeno e médio tráfego geralmente desfrutam da confiança de seus visitantes. (...) Se um ponto de vista abre um caminho pela maioria dos blogs da cauda, o público daquele ponto de vista ou produto irá superar em muito mesmo o maior público dos maiores blogs. Como os visitantes desses blogs de pequeno tráfego estão ligados a eles por alguma razão -

\footnotetext{
${ }^{62}$ http: //technorati.com/weblog/2007/04/328.html, acessado em 18 jun.2007.

63 O autor define cauda como "simplesmente os $95 \%$ a $99 \%$ dos blogs que não recebem um tráfego gigantesco" (p. 143).
} 
amigos, parentes, colegas de trabalho - o impacto do comentário será maior do que se um estranho visitar um blog conhecido" (HEWITT, 2005, p. 143-144).

ANDERSON argumenta de forma semelhante: “E se $99,9 \%$ dos blogs nunca atraírem público pouco superior a algumas dúzias de indivíduos? A fração de $1 \%$ que se destacar ainda se enquadrará na casa dos milhares. E, em conjunto, esse percentual ínfimo talvez atraia tanto tráfego quanto muitos veículos da grande mídia” (ANDERSON, 2006, p. 79). 


\section{Capítulo 3 - 0 novo cenário comunicativo e o jornalismo contemporâneo}

\section{1 - O foco é o usuário: a Internet como plataforma para o saber coletivo}

O advento da Internet e o aperfeiçoamento das tecnologias de comunicação suscitaram enormes transformações na vida humana na última década do século XX e no início do século XXI. Manuel Castells, sociólogo espanhol e um dos maiores estudiosos do tema, enxerga nesses eventos uma Revolução da Tecnologia da Informação e a compara à Revolução Industrial do século XVIII pelo tamanho e diversidade de seu impacto na sociedade (CASTELLS, 1999, p. 71-75).

Ao esboçar os aspectos centrais do novo paradigma da informação (CASTELLS, 1999, p. 108), o autor espanhol cita como características principais a penetrabilidade de seus efeitos, ou seja, os processos de toda atividade humana são diretamente moldados pelo novo meio tecnológico e, principalmente, a aceleração do que denomina um "ciclo de realimentação" entre a introdução de uma nova tecnologia, os usos a ela associados e a expansão de seu desenvolvimento para outros domínios.

(...) a difusão da tecnologia amplifica seu poder de forma infinita, à medida que os usuários apropriam-se dela e a redefinem. As novas tecnologias da informação não são simplesmente ferramentas a serem aplicadas, mas processos a serem desenvolvidos. Usuários e criadores podem tornar-se a mesma coisa. Dessa forma, os usuários podem assumir o controle da tecnologia como no caso da Internet (CASTELLS, 1999, p. 69).

Já WOLTON (2003) versa sobre as conseqüências psicológicas do advento das novas tecnologias em um contexto em que a humanidade cada vez mais é 
marcada pelo individualismo e pelo que denomina cultura do "do it yourself" ${ }^{64}$, que estaria espalhada em todas as esferas da vida contemporânea.

As novas tecnologias (...) simbolizam a liberdade e a capacidade de dominar o tempo e o espaço, um pouco como os automóveis nos anos 30. Três palavras são essenciais para compreender o sucesso das novas tecnologias: autonomia, domínio e velocidade. Cada um pode agir, sem intermediário, quando bem quiser, sem filtro nem hierarquia e, ainda mais, em tempo real. Eu não espero, eu ajo e o resultado é imediato. Isto gera um sentimento de liberdade absoluta, até mesmo de poder (...) (WOLTON, 2003, p. 85).

Um dos principais frutos da aplicação do novo paradigma da informação e do desenvolvimento tecnológico, a Internet vem progressivamente definindo-se como plataforma para a ação dos usuários, como meio a propiciar e incentivar a ampliação do saber coletivo. A Time Magazine, revista semanal noticiosa de maior circulação nos EUA, que em 2006 teve uma média de 4,082 milhões de exemplares vendidos por edição $0^{65}$, elegeu "Você" como "A pessoa do ano" em 2006, em referência ao fato de que, a cada dia, um número maior de pessoas utiliza as diversas potencialidades da Internet para criar e disponibilizar conteúdo na rede mundial de computadores, na maior parte das vezes, sem receber qualquer compensação financeira por isto.

Para explicar este fenômeno, tem se popularizado a utilização do termo "web 2.0", cunhado em 2003 por Tim O'Reilly, fundador e presidente da O'Reilly Media, uma das principais editoras de livros sobre computação e novas mídias dos Estados Unidos.

\footnotetext{
64 Tradução: "faça você mesmo".

${ }^{65}$ De acordo com levantamento da Magazine Publishers of America, disponível em http://www.magazine.org/circulation/circulation_trends_and_magazine_handbook/22175.cfm. Acesso em 19 jun.2007.
} 
Web 2.0 é a revolução nos negócios da indústria da computação provocada pela mudança para a Internet como plataforma, e uma tentativa de entender as regras para o sucesso nesta nova plataforma. A principal destas regras é esta: construir aplicações que aproveitem os efeitos da rede para que melhorem à medida que o público as utiliza (O’REILLY, 2006).

Para compreender melhor a vasta gama de conceitos associados ao termo web 2.0, convém enunciar alguns de seus princípios, bem como apresentar alguns exemplos e comparações. Em primeiro lugar, há o propósito de se valorizar a inteligência coletiva, a colaboração entre os usuários. "O cérebro coletivo funciona mais rápido, com um maior número de sinapses” (DREZNER e FARRELL, 2004, p. 16). Assim, encaixa-se neste conceito, por exemplo, a disponibilização de softwares que não são fechados e, sim, versões iniciais, prontas a serem modificadas, melhoradas ou adaptadas a necessidades diversas. É o caso dos softwares livres, de que o Linux ${ }^{66}$ talvez seja o maior exemplo. 0 setor de jogos eletrônicos também é um dos mais afetados por este paradigma. Como exemplo, pode-se citar a criação do Counter-Strike (BOWMAN e WILLIS, 2003, p. 19). Moldado para ser jogado online por diversos participantes simultaneamente, em 2003 já havia vendido 1,3 milhões de cópias (BOWMAN e WILLIS, 2003, p. 20) e é, na realidade, uma modificação do jogo “Half-Life”. As alterações que o criador do Counter-Strike, Minh Le, realizou foram efetuadas por meio de ferramentas retiradas do website da companhia criadora do "Half-Life" (BOWMAN e WILLIS, 2003, p. 19-20). A Wikipedia, enciclopédia online, também segue a mesma linha: são os usuários que inserem os verbetes e os melhoram indefinidamente. 0 papel do corpo de direção e administração do site foi, inicialmente, disponibilizar a

\footnotetext{
66 Linux é um sistema operacional para computadores que pode ter seu código-fonte modificado e redistribuído por qualquer pessoa, gratuitamente. Sua primeira versão data de 1991.
} 
ferramenta e, agora, é cuidar da sua manutenção, excluindo dados incorretos e mediando debates e discussões quanto à pertinência de determinadas assertivas incluídas no site. Serviços como o Del.icio.us e o Flickr, ao implementarem e incentivarem as tags, permitiram que os internautas definissem quais são as palavras-chave relevantes, em vez de optarem pela imposição de etiquetas e categorias pré-estabelecidas.

Outro princípio decorrente da valorização da participação do usuário são serviços que melhoram à medida que cresce o número de participantes. Em vez de reunir um vasto número de músicas e cobrar para que os usuários as acessassem, assumindo um papel de central de canções, o já extinto Napster apresentou uma plataforma para que as pessoas interagissem e compartilhassem seus arquivos gratuitamente. Ou seja, usou a Internet como plataforma, criando um ambiente e parâmetros de forma a viabilizar a ação dos usuários, que por meio de sua participação, são os responsáveis por agregar valor à ferramenta. Mais tarde, o sistema seria aperfeiçoado por outros serviços, como o Bit Torrent $^{67}$, que fragmenta os arquivos, permitindo que múltiplas fontes alimentem um download. Assim, quanto mais popular uma música ou álbum, mais rápido o interessado consegue obtê-lo. A livraria online Amazon criou um sistema que não só estimula os usuários a fazerem resenhas e comentários sobre os livros à venda, como contem com possibilidades de interação em quase todas as suas páginas. Mais importante ainda, aos poucos, acumulou um vasto conteúdo produzido pelos internautas e soube aproveitá-lo para melhorar as opções de busca e os

\footnotetext{
${ }^{67}$ http: //www.bittorrent.com/. Acesso em 22 jun. 2007.
} 
dispositivos que fornecem ao público sugestões correlatas aos itens pesquisados, diferenciando-se das livrarias convencionais na Internet. 0 site de comércio eletrônico E-bay ${ }^{68}$ é outro exemplo: permitiu que seus usuários disponibilizassem bens e determinassem os preços pelos quais venderiam seus produtos (O'REILLY, 2005). Além disso, estabeleceu um serviço pelo qual os usuários avaliam o desempenho de quem vende. Desta forma, antes de comprar um produto, o consumidor pode checar a reputação do anunciante. Este, por sua vez, de acordo com as avaliações e o número de mercadorias vendidas, pode transformar-se em um "power seller69", ganhando alguns benefícios, como maior visibilidade nas buscas e prazos maiores para pagamento de taxas. Assim como a Amazon, o Ebay melhora à medida que se expande o número de usuários.

Um terceiro conceito importante relacionado à denominação web 2.0, também decorrente do primeiro princípio enunciado, é que “o valor de um software é proporcional à escala e ao dinamismo da informação que ele ajuda a manipular" (O’REILLY, 2005). A Netscape apostava que seu domínio sobre o mercado de navegadores daria a possibilidade de controlar os padrões de exibição do conteúdo. Ou seja, lançaria novas versões de seu produto e os usuários as comprariam. Já o Google, exemplo de companhia da web 2.0, não vende nem licencia softwares. Disponibiliza seu serviço gratuitamente e melhora seu conteúdo paulatinamente, sem lançar novas versões (O’REILLY, 2005).

Como o conceito de web 2.0 pretende abarcar uma série de fenômenos inclusive o advento e popularização dos blogs (O’REILLY, 2005)- que não são

\footnotetext{
${ }^{68} \mathrm{http}$ // /www.ebay.com/. Acesso em 19 jun. 2007.

69 Em tradução literal, "vendedor poderoso". Para saber mais sobre o sistema:

http://pages.ebay.com/services/buyandsell/welcome.html. Acesso em 12 nov. 2008.
} 
todos simultâneos, emergiram progressivamente e, de fato, reúnem alguns produtos -como é o caso do Linux, por exemplo, cuja primeira versão data de 1991- e algumas características presentes desde as primeiras idéias da Internet, críticas ao termo se expandiram. SHAW (2005), por exemplo, enxerga em web 2.0 apenas um slogan de marketing a reunir em um só conceito desdobramentos de fenômenos que não estariam interligados. MADDEN e FOX (2006) citam que "apesar de escritores de tecnologia e analistas terem devotado inúmeras horas usando aplicações da web 2.0 (como blogs) para debater a definição do termo", ainda há pouco consenso "sobre onde 1.0 acaba e 2.0 começa" (2006, p. 1). Para as pesquisadoras, entretanto, a ausência de uma linha divisória e os diferentes significados atribuídos à expressão web 2.0 não são relevantes:

O fato de o termo ter sido sujeito de constantes mutações de significado e interpretações é, de várias formas, o sinal mais claro de sua utilidade. É esta a natureza dos monstros conceituais na era digital e um dos mais reveladores dados sobre o que as aplicações 2.0 fazem: substituem 0 peso autoritário das instituições tradicionais pela emergente sabedoria das multidões (MADDEN e FOX, 2006, p. 2).

Também para o escopo deste trabalho, mais importante do que a atribuição de um nome ou a discussão da pertinência de um rótulo único, é a compreensão do ambiente que emergiu na Web nos últimos anos, que instrumentalizou a “necessidade de agir e a capacidade de interação que caracterizam os indivíduos da sociedade moderna (...)" (WOLTON, 2003, p. 87). Neste contexto, a evolução das ferramentas e dispositivos para a geração de conteúdo em diversos formatos de mídia vem ampliando as possibilidades de intervenção e participação do 
usuário. E, a partir daqui, passamos a focalizar especificamente os efeitos das inovações no panorama comunicativo.

A web abriu um amplo leque de opções para a distribuição de informação (listas de correio eletrônico, grupos de notícias, boletins e fontes RSS), para a publicação de informações e opiniões (fóruns, páginas pessoais, e-zines) e para a criação de comunidades e espaços de trabalho cooperativo (redes sociais, wikis e comunidades virtuais). Além disso, contribuiu para potencializar a interação social por meio dos chats de texto, áudio e vídeo e os serviços de mensagem instantânea (ORIHUELA, 2006, p. 66).

Ao conjunto de dispositivos que colocam o usuário como eixo do processo comunicativo, teóricos espanhóis, principalmente, vêm associando o nome de “meios sociais", que "se definem pela convergência de indivíduos em redes sociais, o uso de novos meios e a sindicação ou enlace de idéias, escritos e outros conteúdos informativos e de opinião. São meios participativos em que a informação (...) se define como uma conversação” (VARELA, 2005, p. 98). Além das ferramentas supracitadas, também vêm sendo encaixados dentro desta definição de meio social os blogs, em motivo das características mencionadas no capítulo 2 deste trabalho, principalmente a possibilidade de formação de comunidades e a facilidade de publicação gratuita de qualquer conteúdo sem intermediação.

Um mundo aberto acessível a todos, e que finalmente dá uma chance a cada um, quais sejam seu itinerário profissional e seus diplomas. E é por isso que as novas tecnologias adquiriram uma dimensão social: elas representam um pouco 'uma nova chance' para todos aqueles que perderam a primeira. As novas tecnologias são, como uma figura de emancipação individual, 'uma nova fronteira'. Não é somente a abundância, a liberdade e a ausência de controle que seduzem, como também essa idéia de uma autopromoção possível, de uma escola sem mestre, nem controle (WOLTON, 2003, p. 85-86). 


\section{2 - 0 jornalismo contemporâneo}

O novo cenário comunicativo exposto neste capítulo, com a emergência dos meios sociais e uma cultura de ação e intervenção do cidadão comum na Internet altera parâmetros fundamentais sob os quais o jornalismo se desenvolveu no último século, impõe novas questões, conceitos e desafios aos veículos tradicionais de mídia e instiga a emergência de novas modalidades de práticas jornalísticas.

Nos últimos anos, teóricos passaram a debruçar-se sobre o fenômeno de produção de conteúdo jornalístico por cidadãos e daí emergiram uma série de nomes como jornalismo participativo, jornalismo open source ${ }^{70}$, jornalismo cidadão, jornalismo público, jornalismo 3.0 e jornalismo de base ${ }^{71}$. Como o tema ainda é muito recente, nenhuma destas definições logrou amplo reconhecimento acadêmico de forma a tornar-se preponderante. Ainda que haja nuances e diferenças de ênfase entre estas definições, todas têm como cerne o advento dos meios sociais e a participação do público na produção de conteúdo. Ao definirem jornalismo participativo, BOWMAN e WILLIS apontam características presentes também nas outras definições:

$\mathrm{O}$ ato de um cidadão, ou grupo de cidadãos, exercendo papel ativo no processo de coleta, reportagem, análise e disseminação de notícias e informações. O intento desta participação é propiciar informação independente, confiável, precisa, de longo alcance e relevante que uma democracia requer (BOWMAN e WILLIS, 2003, p. 9).

\footnotetext{
${ }^{70}$ A tradução mais utilizada de "open source”, expressão popularizada pela distribuição de softwares livres na Internet, é "código aberto".

${ }^{71}$ Tradução do inglês Grassroots Journalism
} 
ORIHUELA (2004c) destaca ainda outras propriedades comuns aos termos: são tarefas de agregação, contraste, análise, opinião e geração de informação em diversos formatos, normalmente à margem dos meios de comunicação tradicionais; a comunicação pública é entendida e praticada como um diálogo; baseiam-se no fato de que o saber coletivo de uma comunidade é sempre maior do que o de um redator; são transmitidas de forma horizontal: do cidadão para o cidadão.

Há, ainda, outro fator, em geral comum a estas acepções para a nova modalidade de prática jornalística, que a diferencia do modus operandi dos meios de comunicação tradicionais: salvo algumas exceções que serão discutidas adiante, ao configurarem-se como práticas de publicação sem intermediação, procede-se uma inversão na ordem dos processos de produção.

A ordem das coisas no jornalismo sempre foi 'filtrar, depois publicar'. A ordem nas comunidades é 'publicar, depois filtrar'. Se você vai a uma festa, você não submete seus comentários aos organizadores, para que eles te digam quais são bons o suficiente para você levar aos convidados, mas é assim que o jornalismo trabalha todos os dias. Repórteres submetem suas histórias previamente, para que sejam editadas ou rejeitadas antes que o público as veja. Participantes de uma comunidade, em contraste, dizem o que têm de dizer, e o bom é separado do medíocre depois disso (SHIRKY, 2003b).

Ainda que o ritmo acelerado de modificações característico da dinâmica de evolução da Internet e a fragmentação inerente à rede tornem praticamente inviáveis definições e classificações completas e estanques, duas formas principais destas experiências focadas no cidadão têm emergido nos últimos anos: veículos noticiosos, em geral dotados de dispositivos colaborativos, em que 
o conteúdo é produzido por qualquer pessoa interessada, e os blogs, cuja multiplicidade de usos, discutida no capítulo 2, abrange também o jornalismo.

\subsection{1 - Veículos colaborativos com viés noticioso}

Diversas experiências de sites baseados na participação ativa de usuários vêm sendo desenvolvidas nesta década na Internet. Aqui, serão discutidas as que geram conteúdo primordialmente em formatos semelhantes aos de notícias -não é o cerne do trabalho, como referido no capítulo 1 , determinar se as ditas “notícias" veiculadas por pessoas comuns se configuram mesmo como tais ou se o produto destes sites atendem a todos os critérios atribuídos ao conceito de “jornalismo” e, sim, destacar que, apesar das diferenças temáticas, de ferramentas utilizadas para o funcionamento e mesmo de propósitos entre as iniciativas, todas procuram, de uma forma ou de outra, criar e estabelecer ambientes que permitam a publicação de conteúdo pelos usuários, incentivem a formação de comunidades e facilitem a interação entre o autor (ou autores) de textos e os leitores, tanto para que surjam conversações em torno do que foi publicado quanto para que este conteúdo possa ser corrigido e melhorado, direta ou indiretamente. Sem qualquer pretensão de circunscrever os diversos modelos de sites colaborativos em categorias, três exemplos serão citados para indicar algumas das possibilidades deste emergente formato ao qual muitos têm atribuído o nome de jornalismo e que está a introduzir novos componentes no campo do conhecimento em que se insere o jornalismo tradicional. 
Talvez o caso mais conhecido no meio acadêmico de site colaborativo que busca veicular notícias seja o sul-coreano OhMyNews ${ }^{72}$. Fundado em fevereiro de 2000 (BRAMBILLA, 2005, p. 4), surgiu como uma alternativa ao domínio de três grupos de mídia, que controlavam cerca de $80 \%$ da imprensa local (PRIMO e TRÄSEL, 2006, p. 5). Em 2003, contava com 26 mil intitulados repórterescidadãos cadastrados (BLOOD, 2003) e uma equipe de 50 jornalistas que funcionavam como editores. Em abril de 2006, recebia cerca de 700 mil visitantes únicos por dia e tinha aproximadamente 2 milhões de páginas vistas diariamente (KLUTH, 2006). Para atuar como colaborador, é necessário cadastrar-se no site, apresentando inclusive cópia de documentos (BRAMBILLA, 2005, p. 5). Nem todas as estórias enviadas são publicadas (BRAMBILLA, 2005, p. 7); as consideradas aptas a veiculação são dividas em seis categorias de relevância, que indicam a quantia de dinheiro a que o autor terá direito -para que haja efetivamente pagamento, o jornalista-cidadão tinha, em 2005, de veicular ao menos três notícias dignas de serem içadas à manchete do site (BRAMBILLA, 2005, p. 6). No início de 2006, estava disponível uma outra forma de remuneração aos colaboradores: um sistema pelo qual os leitores que gostassem de uma notícia poderiam recompensar o repórter clicando em um botão de "contribuição" no site e fornecendo o número do cartão de crédito; em cinco dias, um repórter-cidadão amealhou US\$ 30 mil (KLUTH, 2006). Há, também, um código de ética, que deve ser aceito durante a solicitação de uma identidade de cidadão-repórter, e inclui, entre outras coisas:

72 http: / /english.ohmynews.com/. Acesso em 20 jun.2007 
(...) não produzir cartões de visita onde se auto-identifique como cidadão-repórter do OhMyNews; (...) revelar claramente todas as fontes usadas na produção dos textos; responsabilizar-se inteiramente por eventuais casos de plágio ou uso sem autorização de material bem como pela publicação de inverdades; ser responsável legal caso seus artigos contenham conteúdo difamatório (BRAMBILLA, 2005, p. 6).

Lançado em dezembro de 2004, o norte-americano Digg.com ${ }^{73}$, é uma experiência ainda mais radical do que a do OhMyNews. Nele, não há praticamente intervenção de editores -apenas a remoção de textos com informações indevidas ou plagiadas (PROJECT FOR EXCELLENCE IN JOURNALISM, 2007), ou seja, o público produz, comenta e escolhe as estórias de que gosta mais, por meio de um mecanismo de votos positivos ("digg") e negativos (“bury”). O processo de cadastro, necessário para a publicação de histórias e comentários, é simples (nome completo e e-mail, apenas, são pré-requisitos), mas o site não oferece recompensa financeira aos colaboradores. O Digg.com é dividido em seis editorias: tecnologia, ciências, mundo e negócios, esportes, entretenimento e jogos. Para publicar, basta estar cadastrado e escrever. Inicialmente, o texto fica na seção “upcoming stories" (algo como "estórias que estão chegando"), à disposição dos participantes, que podem aprová-lo ou não. Então, os que recebem o maior número de pontos entram na primeira página das editorias e os mais populares, na capa do site. Só podem publicar comentários os usuários cadastrados. É possível, também, visualizar o histórico de textos escritos para o site por cada indivíduo.

\footnotetext{
${ }^{73}$ http: //digg.com. Acesso em 21 jun. 2007.
} 
No Brasil, há também experiências com sites colaborativos, como é o caso do Overmundo ${ }^{74}$, disponível na Internet desde março de 2006. O veículo funciona em um esquema semelhante ao do Digg.com, mas é voltado especificamente para a divulgação de informações e eventos relacionados à produção cultural. Assim como no Digg.com, há necessidade de cadastro. Além de "notícias" e resenhas, que podem ser inseridas em qualquer formato de mídia, o site veicula um blog coletivo, guias culturais de cidades e uma agenda de eventos. 0 cidadão que deseja publicar algo nestas modalidades insere o conteúdo no site. Por 48 horas, ele permanece em uma "fila de edição". 0 autor pode alterá-lo indefinidamente neste período, e pessoas cadastradas, enviarem comentários -em junho de 2007, havia quatro moderadores, que se comprometiam a usar o poder de edição apenas em casos excepcionais -como o da existência de um "alerta", seção utilizada para que informações equivocadas e plágio, por exemplo, sejam comunicados. Após dois dias, o material passa para a "fila de votação", em que os usuários cadastrados decidem se haverá, ou não, publicação -é necessário atingir um número mínimo de pontos. Assim como no Digg, cada participante possui um perfil -em que são listadas todas as publicações efetivas e as tentativas mal-sucedidas, bem como foto, endereço de blog ou site pessoal e campo para envio de mensagem. O site também introduz uma inovação em relação ao Digg: cada cadastrado recebe "karmas" de acordo com cada modalidade de intervenção (produção, comentário e voto). Ou seja, é possível verificar o histórico de participação dos autores e quem são os mais atuantes.

\footnotetext{
${ }^{74}$ http: //www.overmundo.com.br/. Acesso em 12 nov. 2008.
} 


\subsection{2 - Os blogs}

Um dos mais antigos e estéreis debates da blogosfera começa com a pergunta sobre se os blogs são jornalismo. Uma pergunta mal embasada que só consegue fazer encalhar o que poderia ser uma discussão interessante. Do mesmo modo que os livros não são literatura, nem os filmes são comédias, aqui do que se trata é separar, uma vez mais, o meio do gênero (...). Os weblogs (...) podem ser qualquer coisa, inclusive jornalismo, mas os que são jornalismo não o são por serem weblogs, mas, sim, por outras razões. (...) Por outro lado, milhões de cidadãos escrevendo diariamente sobre o que lhes acontece, sobre o que pensam, do que vêem, lêem ou escutam nos meios, dos governos locais, regionais e nacionais, de empresas e seus produtos, é algo que acaba tendo uma repercussão que transcende a importância relativa de cada blogueiro (ORIHUELA, 2006, p. 155-157).

Não é propósito deste trabalho contribuir para a polêmica alimentada há meia década entre blogueiros, jornalistas e acadêmicos sobre a pertinência da caracterização ou não de determinados tipos de blog como jornalismo. Mais adequado aos propósitos almejados aqui se configura expor dados, fatos e analisar os efeitos provocados pela crescente adoção da ferramenta multiuso facilitadora da publicação de conteúdo produzido por qualquer pessoa para o universo jornalístico.

Os blogs vêm sendo uma ferramenta fundamental para que cidadãos divulguem informações, fotos e vídeos de catástrofes, atentados terroristas e eventos de grande repercussão. Com a evolução dos equipamentos eletrônicos, como celulares com grande capacidade de memória e máquinas fotográficas com câmeras de vídeo acopladas, testemunhas ou vítimas de tragédias têm registrado imagens nos locais em que os eventos acontecem e publicado o material, bem como depoimentos, em blogs, que acabam sendo as primeiras fontes de notícias em diversos acontecimentos relevantes. Muitos teóricos, como GILLMOR (2004, p. 
1), apontam os ataques da rede terrorista islâmica Al-Qaeda contra os EUA, em 11 de setembro de 2001, como marcos iniciais do descobrimento dos blogs como forma de divulgação da visão pessoal de experiências durante grandes acontecimentos. A partir daí, os exemplos vêm se sucedendo.

A catástrofe provocada pelo tsunami de dezembro de 2004 no Sudeste Asiático é um exemplo. Uma semana após o desastre, o Centro de Pesquisas de Internet da Cingapura (SIRC), em colaboração com os institutos Web Archivist e Internet Archive, começou a coletar e arquivar material veiculado na rede mundial de computadores sobre o tsunami, seus impactos e formas de auxílio aos afetados. Foram armazenados ${ }^{75} 1.599$ sites produzidos em mais de 40 países, em 13 línguas diferentes. Destes, 11\% eram blogs (JYH e LENG, 2005, p. 11-12).

De acordo com levantamento realizado por JYH e LENG (2005, p. 14-15), das 94 fotos ou vídeos produzidos durante o impacto das ondas gigantes no sudeste asiático e exibidas no universo dos 175 blogs capturados, 93 eram de amadores, ou seja, não-jornalistas. Entre as imagens de destruição subseqüentes ao desastre, só 16 das 117 veiculadas por blogs eram provenientes de veículos tradicionais de imprensa. Das 17 fotos ou vídeos presentes em mais de um website, ou seja, em teoria as imagens mais impressionantes da tragédia, 13 foram produtos do trabalho de amadores. Como destacam os autores, agências de notícias profissionais, depois, distribuíram boa parte destas imagens ao mundo (JYH e LENG, 2005, p. 14).

\footnotetext{
${ }^{75}$ Os arquivos produzidos pelo SIRC continuam disponíveis online em http://tsunami.archive.org. Acesso em 23 jun. 2007
} 
Ao menos dois blogs produzidos por cidadãos durante o tsunami obtiveram repercussão mundial. Hellmut Issels, um turista alemão que estava em um hotel de Phuket, na Tailândia, postou em um fotoblog ${ }^{76}$ dezenas de imagens do momento em que o tsunami invade a cidade. Rick Von Feldt, um norte-americano que também estava em Phuket, criou um blog ${ }^{77}$ para relatar o que presenciou. Poucos dias depois, decidiu abrir o espaço para o relato de outros sobreviventes da tragédia. Recebeu dezenas de textos, principalmente de cidadãos provenientes de países que adotam a língua inglesa, como norte-americanos, britânicos e sul-africanos. Acabou transformando-se em fonte de referência para a imprensa tradicional: as histórias veiculadas em seu espaço foram reproduzidas pelas emissoras CNN e BBC.

E não apenas para a divulgação de informações em primeira mão foram utilizados os blogs durante a tragédia asiática. Como exemplo, pode-se citar o Tsunami Help ${ }^{78}$. O mais comentado dentre os 175 blogs analisados por JYH e LENG nos três meses subseqüentes ao desastre (2005, p. 13) buscava orientar a ajuda às vítimas, apresentava listas de pessoas desaparecidas e concedia links a dezenas de blogs que tratavam do tsunami e seus desdobramentos e outras dezenas de fontes oficiais.

Durante a passagem do Furacão Rita por Houston (EUA), a versão online do jornal Houston Chronicle ${ }^{79}$ criou dois blogs, um alimentado apenas por cidadãos ${ }^{80}$

\footnotetext{
${ }^{76}$ http: //www.pbase.com/issels/phuket_tsunami\&page=1. Acesso em 23 jun. 2007.

${ }^{77}$ http://phukettsunami.blogspot.com/. Acesso em 23 jun. 2007.

78 http://crawls.archive.org/tsunami/20050126024959/http://tsunamihelp.blogspot.com/. Acesso em 23 jun. 2007.

79 http: //www.chron.com/. Acesso em 22 jun. 2007.

80 http: //blogs.chron.com/stormwatchers/archives/2005/09/. Acesso em 22 jun. 2007.
} 
e outro ${ }^{81}$ pelos integrantes do jornal, o que possibilitou a publicação de notícias também por celular, de repórteres que estavam nas ruas da cidade (GLAZER, 2005). Durante o Furacão Katrina, que devastou a cidade de New Orleans (EUA), a redação do principal jornal da cidade, o The Times-Picayune, foi afetada pela destruição. Assim, o principal meio encontrado pela publicação para divulgar suas informações foi um blog ${ }^{82}$. Também em 2005, durante ataque terrorista ao metrô de Londres, cidadãos que viajavam nos trens produziram fotos com seus celulares e as enviaram para seus fotoblogs no Flickr. O sistema adotado pelo site pelo qual os usuários votam e escolhem as imagens de que mais gostam, rapidamente colocou as fotos do ataque entre as mais vistas (KLUTH, 2006). Então, poucos minutos após serem enviadas, estampavam a capa do site Yahoo! ${ }^{83}$ (KLUTH, 2006). Em abril de 2007, quando o sul-coreano Cho Seung-Hui matou 32 pessoas a tiros antes de cometer suicídio no campus de Blacksburg da Universidade de Virginia Tech, um certo "Paul” utilizou o serviço de blogs do site LiveJournal para revelar detalhes do incidente. "O relato de 'Paul' descrevia cenas de terror, a valentia de "Kate", e como ela e outro estudante puseram carteiras contra a porta para evitar que o agressor entrasse na sala de aula" (BOUSA, 2007). Logo depois, a rede britânica BBC incluiu a informação em seus textos e reportagens em vídeo sobre o incidente. A emissora norte-americana ABC News também repercutiu as informações da testemunha (BOUSA, 2007).

Algumas características dos blogs abordadas no capítulo 2 estimulam e possibilitam a influência direta destes no desdobramento de fatos e

\footnotetext{
${ }^{81}$ http://blogs.chron.com/rita/archives/2005/09/. Acesso em 22 jun. 2007.

82 http: //www.nola.com/newslogs/breakingtp/. Acesso em 22 jun. 2007.

83 http://www.yahoo.com/. Acesso em 26 jun. 2007.
} 
acontecimentos que repercutem em diversos setores da sociedade e, por isso, são assuntos que fazem parte do escopo do jornalismo. A facilidade e celeridade de publicação são propriedades que vêm levando pessoas com as mais diversas formações e especialidades a buscarem nos blogs uma maneira de externarem sua opinião e participarem, por vezes com informações e contribuiçõos valiosas, da discussão de temas de interesse público. 0 advento dos mecanismos auxiliares ao estabelecimento de conversações, a existência de comunidades já formadas na blogosfera e a cultura de interligar textos e entradas relevantes permitem que informações de especialistas circulem, sejam debatidas e, por vezes, transformem o rumo de uma investigação, de um processo político, de um fato do interesse restrito a grupos de cidadãos ou mesmo a percepção geral sobre uma notícia de grande repercussão.

Com publicação instantânea e contínua, histórias podem ser compostas gradualmente e com completa transparência. Comentários e links servem como garantias, mantendo o escritor conectado e disponível à audiência. Blogs, ao contrário de matérias impressas, não têm começo ou fim. Não há contagem de palavras ou prazos para a conclusão. Têm a liberdade de seguir uma idéia para onde e como for preciso (NEUMANN, 2006, p. 7).

HEWITT (2005, p. 21) cunha o termo "quatro mitos fundadores da blogosfera" para se referir a quatro casos ocorridos nos EUA que são exemplos práticos da possibilidade enunciada no parágrafo anterior.

O primeiro evento, que provocou a renúncia do senador norte-americano Trent Lott, é citado também por CORNFIELD e CARSON (2004), DREZNER e FARRELL (2004), GILL (2004) e HARPER (2005). No fim de 2002, na festa de comemoração dos 100 anos do também senador James Thurmond, Lott discursou 
em favor do colega e disse que se, em 1948, Thurmond houvesse sido eleito presidente dos EUA, “não teríamos tido todos esses problemas ao longo desses anos" (HEWITT, 2005, p. 37). A plataforma de Thurmond, em 1948, era racista. Dos jornalistas presentes, apenas Ed O’Keefe, da rede de TV ABC News, associou uma coisa à outra. E fez uma reportagem, exibida apenas uma vez, durante a madrugada. No dia seguinte, o site da rede limitou-se a postar um comentário sobre o assunto que, sem repercussão, pareceu morrer. Nos quatro dias seguintes, uma série de blogueiros abordou o tema, recuperou cartazes da campanha de 1948, levantou um histórico das declarações anteriores de Lott, principalmente durante sua juventude, levando a crer que o senador simpatizava com a causa segregacionista (HEWITT, 2005, p. 39-41). A partir daí, alguns veículos de imprensa fizeram reportagens, e a pressão continuou até que ele renunciasse ao cargo, menos de duas semanas depois.

O segundo caso é um evento subseqüente à revelação de que o jornalista do The New York Times Jayson Blair havia forjado reportagens publicadas pelo jornal. A demissão do repórter não encerrou o assunto porque a blogosfera levantou a hipótese -mais tarde, confirmada- de que Blair só havia conseguido uma evolução rápida no jornal por ser afro-descendente; publicou memorandos internos do The New York Times em que a questão era debatida; levantou dados que apontavam negligência na supervisão do editor-executivo Howell Raines, e questionamentos de repórteres ao seu estilo de comando e às diretrizes que defendia (HEWITT, 2005, p. 45-46). Raines acabou demitido. 
O terceiro evento refere-se à revelação de exageros e supostas inverdades do então candidato a presidente dos EUA, John Kerry, sobre sua participação na Guerra do Vietnã, um dos temas preponderantes nas eleições de 2004. Um grupo de veteranos de guerra criou um blog, o Swift Boat Veterans for $\operatorname{Truth}^{84}$, em que questionava uma série de declarações públicas do candidato (HEWITT, 2005, p. 57-68). As acusações dos militares circularam pela blogosfera, com outros blogs de ex-militares adicionando novas informações, mas foram ignoradas pela imprensa americana. Kerry não adotou a mesma postura e preferiu rebatê-las. Então, a grande imprensa abordou o assunto, referendou algumas das supostas inverdades e provocou enorme desgaste para a campanha do candidato que acabaria derrotado por George W. Bush nas urnas.

Um mês depois, novamente os blogs exerceram papel preponderante, desta vez para apontar uma fraude em uma reportagem contra Bush, em episódio que culminou na saída, após 44 anos, do âncora Dan Rather do canal CBS. Rather apresentou uma edição do programa 60 Minutos que, baseada em quatro documentos supostamente produzidos em 1972 e 1973, acusava Bush de ter recebido tratamento preferencial na Guarda Aérea Nacional dos EUA apesar de ter desobedecido a ordens (CORNFIELD e CARSON, 2004, p. 20). No dia seguinte, os documentos foram publicados na Internet, e a fraude começou a ser desmascarada por um advogado, que publicou um post em seu blog no Free Republic $^{85}$ sob o codinome de Buckhead afirmando que o espaçamento proporcional entre os caracteres de texto do memorando, inovação permitida por

\footnotetext{
${ }^{84}$ http: //www.swiftvets.com/. Acesso em 22 jun. 2007.

85 http://www.freerepublic.com/._Acesso em 22 jun. 2007.
} 
impressoras a laser e processadores de texto que se tornaram de uso corrente na década de 1990, não poderia ter sido produzido por máquinas de escrever -meio usado no início da década de 1970. A informação correu nos blogs favoráveis a Bush e a notícia foi mais tarde divulgada pela grande imprensa. Meses depois, Rather renunciou, antes mesmo de uma perícia efetivamente comprovar a falsificação dos documentos.

BENKLER (2006) cita outro episódio que retrata a influência dos blogs. A Sinclair Broadcasting, rede de TV americana com 62 afiliadas, decidiu veicular, a dez dias das eleições de 2004 nos EUA, um documentário atacando a participação de John Kerry na Guerra do Vietnã. Um repórter se opôs e acabou demitido. 0 Los Angeles Times foi o único grande jornal do país que publicou a história. Então, três dos blogs de maior audiência nos EUA ("Talking Points Memo" “MyDD" e "Daily Kos" ${ }^{88 ”), ~ a d o t a r a m ~ a ~ c a u s a . ~ " M y D D ” ~ p o s t o u ~ o s ~ n u ́ m e r o s ~ d e ~}$ telefone de todas as 62 emissoras, incitando seus leitores a ligarem para reclamar. "Daily Kos" publicou a lista de todos os anunciantes nacionais da Sinclair. Um cidadão até então desconhecido, Nick Davis, criou o site "BoycottSBG.com". Os blogs deram links para ele. "Talking Points Memo" publicou relato de um ex-funcionário da Sinclair informando que o único ponto sensível para a direção da empresa eram as vendas, ou seja, fazia-se necessário atingir os anunciantes locais. E sugeriu um plano para a execução disso. Muitos leitores enviaram e-mails às empresas. O BoycottSBG.com publicou mensagem de um internauta que mostrava temor diante de ameaças de uma companhia contra

\footnotetext{
${ }^{86}$ http: //www.talkingpointsmemo.com/. Acesso em 25 jun. 2007.

87 http: //www.mydd.com/. Acesso em 25 jun. 2007.

88 http://www.dailykos.com/. Acesso em 25 jun. 2007.
} 
o que denominou $\operatorname{spam}^{89}$ ilegal por parte do reclamante. Davis explicou que a legislação federal que regia o assunto se aplicava apenas a empreendimentos comerciais e forneceu links aos pontos pertinentes da lei. Os principais blogueiros, então, espalharam a nova informação. Menos de uma semana depois, a consultoria Lehman Brothers publicou um relatório de expectativas econômicas da empresa para os próximos 20 meses e incluiu possíveis perdas de anunciantes devido ao caso. No fim de semana, a grande imprensa abordou o tema, relatando que os patrocinadores estavam deixando a Sinclair. Na terça-feira, o preço das ações da corporação estava no nível mais baixo em três anos, após queda de quase $20 \%$. Então, a Sinclair anunciou que não veicularia o programa. $E$ as ações voltaram ao mesmo nível no dia seguinte (BENKLER, 2006, p. 220-225).

Em Portugal, um artigo do advogado Luis Grave Rodrigues publicado em seu blog, “Random Precision"9", acabou por provocar um movimento que culminou na substituição do diretor nacional da Polícia de Segurança Pública, em 2005 (MONTEZ e GAMA, 2006). Rodrigues denunciou que Branquinho Lobo, que ocupava o cargo havia seis meses, acumulava uma pensão de aposentadoria. “0 artigo foi citado em vários jornais, os quais verificaram que as informações eram verdadeiras. A situação do Dr. Branquinho Lobo acabou por ser referida em todos os principais jornais e meios de comunicação social, incluindo os quatro canais de televisão. Poucos dias depois, aquele facto levou à demissão do próprio" (MONTEZ e GAMA, 2006).

\footnotetext{
${ }^{89}$ Spam é uma denominação dada ao uso de ferramentas eletrônicas, principalmente o e-mail, para enviar mensagens não-solicitadas a pessoas.

${ }^{90} \mathrm{http://rprecision.blogspot.com/.} \mathrm{Acesso} \mathrm{em} 5$ nov.2008.
} 
No Brasil, há ao menos dois casos de blogueiros não-jornalistas que contribuíram para preencher páginas de jornal com uma revelação. 0 médico Sérgio Faria, autor do blog Catarro Verde ${ }^{91}$, noticiou em maio de 2001 que o discurso de renúncia do senador Antonio Carlos Magalhães continha trechos plagiados de fala do ex-senador Afonso Arinos. Faria, que tem como "hobby" colecionar arquivos de áudio, colocou em seu blog link para o discurso original (SCHITTINE, 2004, p. 161-162).

No dia 4 de julho de 2007, a Folha de S.Paulo publicou a reportagem “Em blog, delegado aponta corrupção policial"92, relatando que o Ministério Público investigava denúncias que o delegado Roberto Conde Guerra havia publicado em seu blog, o Flit Paralisante ${ }^{93}$. De acordo com a reportagem, Roberto Conde Guerra "cita nominalmente policiais, informa quais delegacias receberiam propina, os métodos dos crimes, valores e os rádios daqueles apontados como corruptos. Há até cópias de documentos da corporação”. A partir de suas primeiras denúncias, Guerra passou a receber -e a publicar em seu blogdenúncias de policiais, escrivãos, delegados e outros integrantes das forças de segurança contra colegas. Baseado nas revelações de Guerra, o Ministério Público denunciou $^{94}$, em 18 de outubro de 2007, o ex-delegado Elpídio Laércio Ferrarezi e sua filha, Carla Abibe Ferrarezi Martinez, por lavagem de dinheiro, falsidade

\footnotetext{
${ }^{91}$ http: //catarro.blogspot.com/. Acesso em 22 jun. 2007.

92 CAMPOS, M; CARAMANTE, A. Em Blog, delegado aponta corrupção policial. Folha de S.Paulo, 4 de julho de 2007. Cotidiano, página C7. Disponível em http://www1.folha.uol.com.br/fsp/cotidian/ff0407200718.htm. Acesso em 5 nov. 2008.

${ }_{93}$ http: / / flitparalisante.blogspot.com - retirado do ar por ordem judicial em 23 de outubro de 2008.

94 Cópia da denúncia está disponível em

http://64.233.169.104/search?q=cache:24WSa6uNlz0J:flitparasilante.blogspot.com/2007/10/dennciaoferecida-pelo-ministrio-

pblico.html+\%22Roberto+Conde+Guerra\%22+\%22minist\%C3\%A9rio+p\%C3\%BAblico\%22\&hl=ptBR\&ct=clnk\&cd=2\&gl=br. Acesso em 5 nov. 2008.
} 
ideológica, corrupção passiva e prevaricação, além de outras três pessoas. A Justiça de Bertioga (SP) acolheu a denúncia, transformando-os em réus.

Conde Guerra continuou a veicular acusações de corrupção contra policiais, inclusive integrantes do alto escalão da Polícia Civil, como o diretor do Denarc (Departamento de Narcóticos), Everardo Tanganelli Júnior, além de comentar assuntos de interesse dos policiais, como a greve da Polícia Civil, no segundo semestre de 2008. Em 23 de outubro de 2008, o juiz Davi Capelato ordenou a retirada do blog do ar. Oito dias depois, em 31 de outubro, Capelato expediu nova ordem judicial ${ }^{95}$, determinando que o Google removesse do ar também o endereço http://flitparasilante.blogspot.com que, como notou o juiz, apenas trocava as letras do endereço do blog. Não adiantou. Relata o blog "Casal 10"96: "como na internet nada pode ser contido, as palavras do delegado ecoam agora em outros 10 sites, que se apagados surgirão 100. Se o site original for removido, outros surgirão. Pois os admiradores do delegado pegaram o cache do Google e criaram cópias do blog". 0 blog Seriguela" revela que "alguns admiradores do trabalho do Flit Paralisante remontaram o blog no Blogspot e no Wordpress ${ }^{98}$, publicando alguns dos textos disponíveis".

O episódio, que pode ter novos desdobramentos após o fim da redação desta dissertação, mostra tanto a importância que os blogs podem ter para unir cidadãos das mais diversas áreas interessados em promover mudanças no status

\footnotetext{
${ }^{95}$ Cópia da ordem judicial está disponível em http://www.sintelpol.org.br/modules/news/article.php?storyid=1233. Acesso em 5 nov. 2008.

${ }^{96} \mathrm{http}$ / //casal10.evonblogs.com.br/?p=649. Acesso em 5 nov. 2008.

97 http://seriguela.com/flit-paralisante-caso-de-policia/. Acesso em 5 nov. 2008.

98 Blogspot (http://www.blogspot.com/) e Wordpress (http://pt-br.wordpress.com/) são serviços gratuitos de hospedagem de blogs.
} 
quo quanto a força da ferramenta para burlar tentativas de intimidação e censura.

O potencial dos blogs para influir no universo jornalístico vem sendo ampliado, a julgar por alguns fatos ocorridos nos últimos anos. A agência britânica de notícias Reuters, que possui representantes em 94 países do mundo ${ }^{99}$ anunciou em abril de 2006 um contrato ${ }^{100}$ com a rede de blogueiros internacional Global Voices Online ${ }^{101}$ (GVO) para agregar as informações e opiniões veiculadas nos blogs da GVO, que tratam de assuntos internacionais, ao conteúdo que distribui a 131 países. A norte-americana Associated Press, outra das maiores agências de notícias do planeta, efetivou uma parceria ${ }^{102}$ em janeiro de 2007 com blogueiros afiliados à Media Bloggers Association ${ }^{103}$, credenciando-os para a cobertura e adquirindo direito de distribuir informações por eles angariadas sobre o julgamento do norte-americano Lewis Libby, que ocupou, entre 2001 e 2005, os cargos de assistente do presidente George W. Bush e de chefe de gabinete do vice-presidente Dick Cheney. Nos EUA, o credenciamento de blogueiros para a cobertura de eventos importantes vem se tornando fato cada vez mais comum. Em 2004, autores de blog participaram da cobertura das convenções do Partido Democrata e do Partido Republicano às eleições presidenciais (ADAMIC e GLANCE, 2005, p. 2). Em 2005, Garrett Graff ${ }^{104}$ tornou-se o primeiro dono de blog a receber permissão para participar das conferências

\footnotetext{
${ }^{99}$ http://about.reuters.com/pressoffice/company/facts/index.asp. Acesso em 23 jun. 2007.

100 Mais informações em http://about.reuters.com/pressoffice/pressreleases/index.asp?pressid=2671. Acesso em 23 jun. 2007

${ }^{101} \mathrm{http}$ ://www.globalvoicesonline.org/. Acesso em 23 jun. 2007.

102 http://mediabloggers.org/mba-news/associated-press-to-carry-bloggers-coverage-of-libby-trial. Acesso em 23 jun. 2007.

103 http: //www.mediabloggers.org/. Acesso em 22 jun. 2007.

104 http://www.garrettgraff.com/blog/. Acesso em 23 jun. 2007.
} 
diárias de imprensa da Casa Branca (SERRA, 2006, p. 535). “Um aspecto (...) nesta tomada de decisão é a de que ela foi influenciada, em grande parte, pela interferência dos jornalistas 'tradicionais' pertencentes à Associação de Correspondentes da Casa Branca, e, nomeadamente, do seu presidente Ron Hutcheson" (SERRA, 2006, p. 535). Em 2006, 40 blogueiros receberam credenciais para a Semana de Moda de Nova York (DODES, 2006). Em abril de 2008, Joshua Micah Marshall, que edita o blog Talking Points Memo $^{105}$, tornou-se o primeiro blogueiro a receber um prêmio relevante de jornalismo no país, o George Polk Award for Legal Reporting ${ }^{106}$.

Duas decisões judiciais, uma no Brasil, outra nos EUA, também são úteis para dimensionar a importância dos blogs. Durante a campanha para a eleição de 2006, quando era candidato a senador pelo Amapá, o ex-presidente José Sarney moveu mais de 20 processos contra a jornalista Alcinéa Cavalcante, que ajudou a articular e divulgar, por meio do seu blog, a campanha "Xô, Sarney”. A Justiça decidiu tirar o blog de Alcinéa do ar e multá-la. A notícia, oriunda do Estado menos populoso do país, teve repercussão pela blogosfera, foi noticiada pelos veículos tradicionais de imprensa e acabou rendendo um prêmio ${ }^{107}$ à jornalista. “Alcinéa relata que, nas ações de Sarney, o senador sempre ressaltava que o blog era mais lido do que os jornais e que isso causava 'um prejuízo maior' à imagem dele” (PERRET, 2008, p.19). Nos EUA, uma decisão judicial insere os blogueiros entre os veículos de imprensa (SERRA, 2006, p. 535-536). Em 26 de maio de 2006,

\footnotetext{
${ }^{105} \mathrm{http}: / /$ www.talkingpointsmemo.com/. Acesso em 5 nov. 2008.

106 http://www.brooklyn.liu.edu/polk/press/2007.html. Acesso em 5 nov.2008.

107 Alcinéa ganhou o prêmio 'Repórteres sem Fronteiras', na votação popular do concurso Best of the Blogs 2006, promovido pela alemã Deutsche Welle (PERRET, 2008, p.19).
} 
a Corte de Apelações da Califórnia baseou-se na Primeira Emenda da Constituição norte-americana e definiu-se contra uma decisão de tribunal de primeira instância favorável à empresa Apple (que demandava que três blogs ${ }^{108}$ revelassem fonte que transmitiu informações confidenciais sobre o produto Asteroid), “não encontrando base de sustentação para distinguir blogueiros 'dos repórteres, editores e publicistas que fornecem notícias ao público através dos meios tradicionais impressos e de teledifusão" (SERRA, 2006, p. 536). Também eles “reúnem, selecionam e preparam, com objetivo de publicação para uma audiência de massas, informação acerca de acontecimentos correntes que suscitam o interesse e a preocupação dessa audiência” (SERRA, 2006, p. 536), escreveu o tribunal.

\subsection{3 - 0 jornalismo tradicional e os novos desafios}

O jornalismo profissional não é mais soberano sobre o território que controlava facilmente. Não ser mais soberano não significa que você vai embora. Significa que sua influência não será mais singular (ROSEN, 2005).

A partir do momento em que mais e mais pessoas produzem conteúdo na Internet, modifica-se uma relação existente entre os órgãos de mídia e a população desde os primórdios do jornalismo: o público, anteriormente um receptor passivo de notícias, passa a assumir um papel híbrido de produtor e consumidor de informações (KOVACH e ROSENSTIEL, 2003, p. 41). Ou seja, as fronteiras entre os jornalistas e o cidadão com acesso à Internet são, cada vez, mais tênues (GILLMOR, 2004, p. 14).

\footnotetext{
${ }^{108}$ Os três blogs em questão são http://thinksecret.com, http://appleinsider.com e http://powerpage.org, acessados em 23 jun. 2007.
} 
A reportagem das notícias, amanhã, será como uma conversação. As linhas que separam produtores e consumidores da informação vão, cada vez mais, se confundir. A rede de comunicação será um meio para a voz de qualquer um (...). A primeira versão da reportagem será apenas o começo de uma conversação para esclarecer a todos. Podemos corrigir nossos erros. Podemos adicionar novos fatos e contexto (GILLMOR, 2004, p. 13).

Esta nova relação entre o público e as empresas jornalísticas gera uma série de conseqüências, de certa forma interligadas, para os jornalistas. Em primeiro lugar, não detêm mais o monopólio de decidir o que é ou não notícia. Em segundo, as práticas cotidianas da profissão passam a ser submetidas a escrutínio público. Em terceiro, com os novos meios existentes para que especialistas em diversos assuntos emitam sua voz, precisam tornar-se mais precisos e criteriosos sob pena de desmentidos públicos e desmoralização. E, finalmente, têm de lidar com um contingente cada vez maior de fontes que difundem informação em tempo real e sem filtragem.

A venerável profissão de jornalismo se encontra em um raro momento da história em que, pela primeira vez, sua hegemonia como guardião das notícias é ameaçada não apenas pela nova tecnologia ou competidores, mas, potencialmente, pela própria audiência a que ele serve. Munida de ferramentas de fácil publicação, conexões rápidas e instrumentos portáteis em constante desenvolvimento, a audiência online tem todos os meios para se tornar participante ativa da criação e disseminação de notícias (BOWMAN e WILLIS, 2003, p. 7).

A necessidade de interação com o público é uma das principais mudanças que o novo cenário comunicativo traz. Afinal, entre os antigos leitores, haverá sempre alguém que conhece mais sobre o assunto tratado ou que presenciou acontecimentos que o jornalista não pôde observar. "O público espera que seus novos fatos passem a fazer parte do registro das notícias" (KOVACH e 
ROSENSTIEL, 2004, p. 41-42). Daí a necessidade de transição da função exercida na sociedade pelo jornalista de professor ou conferencista a um moderador de discussões (KOVACH e ROSENSTIEL, 2003, p. 41), e do paulatino deslocamento da essência das reportagens, que em vez de palestras, passam a se assemelhar a conversações (GILLMOR, 2004, p. 13). O processo, entretanto, é recente, e como constatou SALAVERRÍA (2004, p. 13) em sua análise da cobertura da imprensa dos ataques terroristas de 11 de Março de 2004 em Madri (Espanha), "os meios ainda não sabem lidar com informações de última hora vindas do público".

Um dos pilares históricos do jornalismo sempre foi determinar o que é ou não notícia (SINGER, 2005, p. 178-179). Assim, quando os órgãos de imprensa decidiam que algo não deveria ser publicado, como no caso da invasão da Baía dos Porcos, em Cuba, por mercenários financiados pela CIA, em 1961 -em que o The New York Times omitiu a iminência da invasão e a participação da CIA em nome de ditos interesses nacionais- (TALESE, 1971, p. 17), a notícia não chegava a público. A facilidade que os cidadãos têm de veicular informações, em qualquer formato de mídia na Internet, revoga este monopólio anteriormente em vigor. Mesmo que os órgãos de imprensa silenciem, alguém poderá divulgar histórias de interesse público, como ocorreu com o caso extraconjugal que o então presidente norte-americano Bill Clinton sustentava com a estagiária da Casa Branca Monica Lewinsky. A revista semanal norte-americana Newsweek recusou-se a publicar a história, mas o Drudge Report ${ }^{109}$, site alimentado pelo jornalista Matt Drudge, veiculou a informação de que um repórter da revista

\footnotetext{
${ }^{109}$ http://www.drudgereport.com/. Acesso em 20 jun.2007.
} 
havia apurado o fato e seus superiores haviam decidido abafá-la (SERRA, 2003a, p. 92). Após o relato do Drudge Report, o caso ganhou repercussão mundial, e Bill Clinton admitiu publicamente a relação. Em outras palavras, "o novo jornalista não decide mais o que o público deve saber. Ele ajuda o público a pôr ordem nas coisas. (...) A primeira tarefa dessa mistura de jornalista e 'explicador' é checar se a informação é confiável e ordená-la de forma que o leitor possa entendê-la" (KOVACH e ROSENSTIEL, 2003, p. 41).

Apesar de apresentarem restrições à idéia da transformação do papel do antigo leitor, três diretores dos principais jornais brasileiros, "Folha de S.Paulo", "O Globo" e "O Estado de S.Paulo", têm uma visão semelhante à de Kovach e Rosenstiel no que diz respeito ao papel que os jornais paulatinamente passarão a assumir (SANT'ANNA, 2007, p. 102 e 103).

"Os diretores de redação preferem salientar (...) o valor do trabalho jornalístico de ordenar e de hierarquizar a informação. No ambiente predominantemente caótico e desordenado da Internet, em que a informação se encontra fragmentada, descontextualizada, e sem uma ordem de importância, o trabalho de edição, que caracteriza os jornais, ganharia importância, em vez de perdê-la" (SANT'ANNA, 2007, p. 103).

O fim da exclusividade no papel de "guardião das notícias" dos jornalistas pode, também, contribuir para uma ampliação do horizonte noticioso nas sociedades contemporâneas. A "tribo dos jornalistas" oferece ao mundo "uma 'imagem refratada' que passa através de um 'prisma' -os valores-notícia da comunidade jornalística, tais como o novo, o fora de uso, o sensacional e o controverso" (TRAQUINA, 2005, p. 25). Em outras palavras, os jornalistas partilham de códigos comuns e de uma visão de mundo que de certa forma 
pasteuriza as publicações, fazendo com que os principais veículos de comunicação manifestem uma visão de mundo calcada em princípios e pressupostos semelhantes e, de certa forma, restritos.

Escreve Sigal (1973: 180-181): “Enquanto os repórteres seguirem as mesmas rotinas, adotando os mesmos valores profissionais e tomando-se uns aos outros como padrões de comparação, a reportagem tenderá a ser insular e auto-reforçadora. Mas é precisamente dessa insularidade que os jornalistas precisam. Fornece-lhes um pouco de certeza que lhes permite agir num ambiente aliás incerto". O resultado líquido é uma espécie de “jogo de espelhos' (Bourdieu: 1998:24) que produz um efeito formidável de encerramento mental entre os membros da tribo jornalística. (TRAQUINA, 2005, p.27)

Por outro lado, o fato de muitas pessoas terem assumido o papel de publicar informações, o crescente número de documentos e dados disponíveis na Internet e a facilidade para pesquisar este arsenal também têm aumentado os questionamentos do modus operandi da atividade jornalística. A mídia, ao longo dos anos, manteve-se como uma “caixa preta”, e os jornalistas historicamente não se preocuparam em divulgar seus métodos ou foram submetidos a controles externos (SINGER, 2005, p. 179). Agora, o cenário muda: tudo o que é escrito pelo repórter pode ser analisado, comparado e verificado à exaustão. Há, inclusive, uma série de blogs dedicados ao acompanhamento e análise do comportamento de empresas jornalísticas, como é o caso, no Brasil, do Imprensa Marrom $^{110}$ ou do Contrapauta ${ }^{111}$.

Durante a campanha para a eleição presidencial de 2006, jornalistas puderam ter amostras deste novo contexto. Em post de 13 de outubro de 2006 em seu blog, Fernando Rodrigues afirma que "a campanha presidencial pegou fogo na

\footnotetext{
110 http: / /www.imprensamarrom.com.br/. Acesso em 25 jun. 2007.

111 http://blog.contrapauta.com.br/. Acesso em 25 jun. 2007.
} 
web. Este blogueiro nunca recebeu tantos e-mails (...)". Na mesma linha, Carlos Castilho, do Observatório de Imprensa, observou, em post ${ }^{112}$ publicado em 30 de outubro de 2006, o que denominou de "patrulhamento" dos leitores sobre os jornalistas, "que passam a se sentir encurralados e hostilizados por uma massa de leitores que estraçalha reportagens e comentários com um ímpeto também inédito na história do jornalismo brasileiro".

A necessidade crescente de transparência implica, também, em um aperfeiçoamento, pelos meios de comunicação, do tratamento dado aos erros cometidos, despindo-se da arrogância que os têm caracterizado (ORIHUELA, 2006, p. 70). “Correções em blogs (...) são disseminadas virtualmente de forma instantânea, enquanto quando um membro da mídia tradicional encontra um erro, podem ser necessárias semanas até que uma retratação seja procedida” (POSNER, 2005).

A participação mais ativa dos usuários tanto na produção de conteúdo quanto no questionamento das práticas dos jornalistas vinculados às empresas tradicionais ocorre em um momento em que a credibilidade destas já está abalada por outros fatores, como o distanciamento da missão de defender o interesse público. “(...) as empresas informativas radicalizaram a oferta de produtos descartáveis, apostaram na irrelevância e na futilidade, e adotaram a lógica do lucro a qualquer custo em lugar de suas responsabilidades sociais e de seu compromisso pedagógico de formadoras de opinião. Com isso, os padrões

\footnotetext{
112 http: / / observatorio.ultimosegundo.ig.com.br/blogs.asp?id=\%7BD34FD721-F8FB-456F-99CB88B0F1CF0307\%7D\&id_blog=2. Acesso em 10 nov.2008
} 
éticos se diluíram e perderam-se em lógicas empresariais diversas" (CORRÊA, 2006, p. 9).

Os grandes meios sofrem uma grande crise de credibilidade. Os cidadãos os consideram demasiadamente próximos dos poderes e distantes da realidade. 0 crescimento das grandes corporações, fruto da concentração jornalística, e com interesses em muitos meios, tanto informativos como de entretenimento derrubou o mito do jornalismo como defensor dos cidadãos e o substitui por uma lógica empresarial impiedosa, em ocasiões disposta inclusive a trair as regras mais elementares do jornalismo (VARELA, 2005, p. 131).

Além de sofrerem os efeitos da credibilidade em baixa, as principais empresas informativas terão de enfrentar o novo cenário comunicativo em uma época em que seu modelo de negócio enfrenta dificuldades e suas redações estão mais enxutas. "As famílias que controlavam o Los Angeles Times e o Wall Street Journal venderam a maior parte de suas ações. A New York Times Company viu suas ações caírem 54\% desde 2004, em especial no último ano (2007); em fevereiro (de 2008), o Deutsche Bank recomendou que seus clientes vendessem ações do New York Times” (ALTERMAN, 2008). De acordo com o autor, “de 1990 para cá, um quarto dos empregos no ramo jornalístico desapareceu”. Já o estudo “State of the News Media" de 2006, publicado pelo PROJECT FOR EXCELLENCE IN JOURNALISM, aponta que, nos EUA, em 2005 o ramo tinha 3,5 mil empregos a menos do que em 2000. No Brasil, levantamento publicado pela Folha de S.Paulo em 15 de fevereiro de 2004 dava conta de que, nos dois anos anteriores, 17 mil empregos haviam sido extintos nos veículos de comunicação no país. A circulação dos jornais também enfrenta tendência de queda -ainda que, nos últimos três anos, o IVC (Instituto Verificador de Circulação) tenha apurado um aumento nas tiragens diárias dos jornais, motivada pelo aquecimento da economia, os 
números ainda são mais modestos do que os do início da década: de janeiro a dezembro de 2000 , os 63 jornais cadastrados no instituto somados tiveram uma circulação média diária de 4.718.227 exemplares. Em 2006, mesmo com o universo pesquisado tendo subido para 90, a circulação média diária era menor: 4.491.781. “(...) a diminuição na circulação dos jornais, nesta década, foi um fenômeno estrutural, desvinculado do crescimento econômico e da economia interna das empresas jornalísticas. Sua causa é a mudança nos hábitos de leitura e o deslocamento do consumo de informação nos jornais para a Internet" (SANT'ANNA, 2007, p. 35).

Além de lidar com este quadro, as principais empresas terão de descobrir formas de incorporar às suas práticas as novas possibilidades e demandas originadas, essencialmente, da mudança de papel dos cidadãos para com o jornalismo. Para isso, precisarão superar o que o Readership Institute britânico detectou, em exaustivo estudo publicado em 2000, como uma cultura agressiva/defensiva nas publicações do país, "onde as pessoas realizam as tarefas de forma a proteger seu status e segurança". Para HERMIDA e THURMAN (2006, p.5), os jornais são, via de regra, resistentes a mudanças.

No passado, culturas defensivas eram bem-sucedidas, produzindo produtos $(. .$.$) confiáveis porque as mudanças no contexto como a$ tecnologia, a demografia e a competição moviam-se mais devagar. Hoje, no entanto, estão mal-equipadas para responder às necessidades do consumidor, que se modificam rapidamente, a uma maior competição e a avanços revolucionários na tecnologia (HERMIDA e THURMAN, 2005, p.6).

Para os autores do artigo acima citado, na Inglaterra, os atentados a bomba em Londres, em julho de 2006, são o marco do início de uma mudança lenta de 
postura dos principais veículos, no sentido de utilizar a participação do público em seus produtos finais. Citam como exemplo o tablóide "The Sun", cujo editor afirmou que em média quatro reportagens por semana se originam de informações passadas por leitores. Nas versões online dos jornais britânicos, de acordo com HERMIDA e THURMAN, a grande tendência é que os comentários sejam totalmente moderados, por questões legais (os sites são responsabilizados judicialmente por tudo o que os leitores publicam) e por medo de dano à imagem do veículo, criando um dilema: as organizações pretendem agora utilizar o conteúdo produzido pelo público, mas apenas o que se encaixa na identidade e nos valores da marca (HERMIDA e THURMAN, 2006, p.18). 0 pensamento de um editor do Telegraph, A. van der Belt, revelado em entrevista aos autores, é citado no artigo: "Qual é a porcentagem dos nossos leitores que tem tempo para ler 15 mil comentários em uma matéria? Sentimos que é nosso trabalho exibir os mais interessantes" (HERMIDA e THURMAN, 2006, p.18).

\subsection{4 - A grande imprensa e os blogs}

0 advento dos blogs não é equivalente à morte do jornalismo profissional. $\mathrm{O}$ mundo da mídia não é um jogo de soma zero. $\mathrm{Na}$ realidade, cada vez mais, a Internet está se tornando um ecossistema simbiótico - em que diferentes partes se alimentam e todas crescem (ROSEN, 2005).

A reação dos maiores e mais tradicionais veículos jornalísticos -no Brasil conhecidos como grande imprensa- no mundo à crescente participação das novas formas de jornalismo -e aqui focalizaremos especificamente os blogs, objeto de estudo deste trabalho- no cenário comunicativo teria passado por quatro fases, 
de acordo com ORIHUELA (2006, p.157): ignorância, desprezo, temor e canibalização.

A independência de critério dos blogueiros, sua assumida subjetividade, sua desvinculação do aparato midiático tradicional e sua posição crítica diante das más práticas jornalísticas geram o desprezo midiático em relação à blogosfera, acusações de amadorismo e intrusão, e o irônico apelido com o qual a imprensa batiza os blogueiros: jornalistas de pijama. (...) 0 temor ante os blogs surge à constatação do aumento da influência da blogosfera sobre a opinião pública como fonte alternativa de notícias, e particularmente a raiz das funções de controle de imprensa que está assumindo a blogosfera. (...). A canibalização midiática dos blogs é o processo que consiste em converter colunistas em supostos blogueiros, rebatizando como weblogs as colunas dos meios online, ou no melhor dos casos, incorporar blogueiros ao plantel dos meios (ORIHUELA, 2006, p. 157-158).

A “canibalização" a que se refere o autor significa uma apropriação do uso da ferramenta blog pelas versões online dos veículos tradicionais. Nos EUA, 95 dos 100 maiores jornais americanos contam com blogs de seus profissionais em suas páginas na Internet (MADANSKY e ARENBERG, 2008). Na Inglaterra, entre abril de 2005 e novembro de 2006, o número de blogs de jornalistas nos 12 maiores veículos passou de 7 para 118 (HERMIDA e THURMAN, 2006, p. 13). O fenômeno, mundial, observa-se também no Brasil. Jornalistas consagrados por sua atuação na grande imprensa passaram a escrever blogs para os portais associados aos jornais dos quais são funcionários, como são exemplos Lívio Oricchio ${ }^{113}$, do Estadão, Josias de Souza, da Folha de S. Paulo e Jorge Bastos Moreno ${ }^{114}$, de 0 Globo. Os sites também vêm criando blogs coletivos, alimentados por suas redações, para a cobertura de eventos prolongados, como fez o UOL durante a

\footnotetext{
113 http: //blog.estadao.com.br/blog/livio/. Acesso em 5 nov. 2008.

$114 \mathrm{http://oglobo.globo.com/online/blogs/moreno/.} \mathrm{Acesso} \mathrm{em} 23$ jun. 2007.
} 
Copa do Mundo de futebol ${ }^{115}$, em 2006 , ou pontuais, como fez o site de notícias do portal das Organizações Globo, o G1, para a análise dos bastidores de debates $^{116}$ entre os candidatos à Presidência da República do Brasil em 2006.

Ao utilizar o termo “canibalização", que tem clara conotação pejorativa, ORIHUELA transparece seu ceticismo quanto à atuação de jornalistas como blogueiros. Para ele, a grande imprensa tem dificuldades para ser mais transparente e incorporar visões do público. Em linha semelhante, LOWREY (2006, p. 493), afirma que "as organizações noticiosas parecem mais interessadas em conter e dirigir o fenômeno dos blogs do que promover a participação do público". O pesquisador critica ainda outros aspectos da adoção dos blogs pela grande imprensa. "É pouco provável que blogs de grandes veículos destoem muito da organização que os aloca por necessidade de recursos e medo de constrangimentos legais" (LOWREY, 2006, p. 493).

SINGER (2005) publicou um dos primeiros estudos que aborda especificamente os blogs de jornalistas. Entre fevereiro e março de 2004, foram analisados 20 blogs norte-americanos, todos de jornalistas afiliados a corporações tradicionais de imprensa. As conclusões reforçam o ceticismo de ORIHUELA e LOWREY. Dos 20 blogs, apenas três chegaram a publicar posts com alguma referência a comentários ou e-mails enviados pelos leitores (SINGER, 2006, p. 183). E a autora identificou um padrão claro: "a esmagadora maioria” dos links colocados em posts enviavam o leitor a sites de veículos tradicionais de mídia (SINGER, 2006, p. 187). Ou seja, os blogs de jornalistas analisados no estudo mantiveram o papel

\footnotetext{
115 http: / /blogdaredacao.blog.uol.com.br/. Acesso em 23 jun. 2007.

116 http://g1.globo.com/Noticias/Colunas/0, ,7415,00.html. Acesso em 23 jun. 2007.
} 
de "guardiões da notícia", fortalecendo ainda mais os principais veículos de mídia em detrimento da natureza inerentemente participativa e facilitadora de conversações do meio.

O estudo ampara outras pesquisas que indicam que os jornalistas continuam pensando o seu papel como provedores de informação mesmo quando migram para um meio online e interativo (...), continuando a exercer a comunicação de forma vertical, do jornalista para o usuário, em vez da comunicação horizontal que posiciona o jornalista como participante em uma conversação (SINGER, 2005, p. 192).

Observando a relação entre a grande imprensa e os blogs sob um outro prisma, entretanto, é possível enxergar indícios do "ecossistema simbiótico" que ROSEN (2005) prevê que virá a se configurar. Como afirma SERRA (2006, p. 531), os blogs passaram de rivais a parceiros da grande imprensa, com a mudança da “lógica de substituição” por uma lógica de complementaridade, de "convergência” ou “infiltração e integração". Nos cinco primeiros casos resumidos no item 2.2.2, que ilustram como os blogs lograram alterar a dinâmica de eventos importantes para a sociedade, a blogosfera exerceu o papel de manter assuntos ignorados pela grande imprensa em discussão, o que permitiu que informações relevantes aparecessem e fossem disseminadas. Entretanto, todos os desdobramentos só foram possíveis porque a grande imprensa exerceu, a partir de determinado momento, o papel preponderante de divulgar de forma mais ampla as informações, aumentando, assim, a pressão da opinião pública.

Os blogueiros concordam plenamente que nunca teriam conseguido derrubar Lott sem a ajuda da mídia tradicional. De acordo com (Joshua) Marshall ${ }^{117}$, o ciclo de 24 horas de notícias da mídia tradicional exige que uma matéria 'pegue', e se isso não acontece

117 http://www.talkingpointsmemo.com/. Acesso em 22 jun. 2007. 
não há uma segunda chance. Porém, apesar do fato de que a história de Lott claramente fracassou na primeira vez, os blogs mantiveram a bola rolando tempo suficiente para que as pessoas percebessem que havia ali uma matéria muito maior do que as pessoas tinham achado. (...) Enquanto os blogueiros podiam manter uma história viva e até lançar-se à investigação com um pouco mais de profundidade, a mídia tinha os recursos e os 'grandes megafones' necessários para tornar uma história realmente conhecida (HEWITT, 2005, p. 45-46).

Em relação aos casos de catástrofes, em que os blogs foram importantes por veicularem os primeiros registros e imagens de grandes acontecimentos, a imprensa, mais tarde, condensou o grande número de informações fragmentadas e, com reportagens originais, auxiliou o público a compreender a extensão, as implicações e os motivos dos fenômenos. "Sempre que grandes notícias acontecem inesperadamente, ou em locais remotos e perigosos, há mais informação crua disponível na Internet do que em organizações tradicionais de imprensa (...). Mas, com o tempo, a melhor informação sobre a destruição do furacão vem de repórteres, não de cidadãos” (LEMANN, 2006). ROSEN (2005) cita declarações de Simon Waldman, integrante do jornal britânico The Guardian para explicar o papel complementar entre blogs e grande imprensa. "Uma coisa é você ler cem histórias de pessoas. Outra é saber o que exatamente aconteceu. Isso não acontecerá por uma revolução na distribuição porque se trata de reduzir informação, distilá-la, como acontece na mídia tradicional” (ROSEN 2005).

A utilização dos blogs como fontes para reportagens da grande imprensa é outro indício de que uma convivência mais harmônica vem emergindo. A Folha de S.Paulo, por exemplo, baseou-se em dois blogs de filhos do presidente Luiz Inácio 
Lula da Silva para fazer uma reportagem sobre sua intimidade ${ }^{118}$; em 2008 , o mesmo jornal encontrou um blog de curitibanos ${ }^{119}$ que plantam árvores em locais públicos sem autorização de autoridades como ponto de partida para publicar texto $^{120}$ sobre o tema. Há pesquisas com dados que apontam para um crescimento exponencial do uso de blogs pelos jornais tradicionais em seus textos. DREZNER e FARRELL (2004, p. 5) citam um levantamento do instituto Lexis-Nexis que revela que, nos EUA, entre 1995 e 1999, 11 matérias de jornal citaram blogs. Em 2000, o número subiu para 56. Em 2001, para 128; Em 2002, para 272 e, em 2003, para 647. MESSNER e DISTASO (2006) comandaram um estudo que analisou todos os textos dos jornais norte-americanos The New York Times e Washington Post em um período de seis anos. As conclusões são semelhantes. Em 2000, só um artigo mencionava blog. Em 2001, foram 10. Em 2002, 57; em 2003, 208; em 2004, 488. E, em 2005, 1295 reportagens abordavam blogs. Do universo de 2059 artigos em que apareceram, os blogs foram alvo de menções secundárias em 46\%. Em 38\%, as reportagens os utilizavam como fontes. $E$, em $15 \%$, os blogs foram o tema das histórias. Um estudo menos abrangente, mas referente à realidade brasileira, produzido por BERTOCCHI (2006), catalogou durante um mês as fontes utilizadas pela coluna "Toda Mídia”, criada em 2004, dedicada à repercussão de notícias em outras mídias e publicada de segunda a sexta-feira no jornal Folha de S.Paulo. A conclusão é que “os blogs (...) estão representados tantas vezes quanto as revistas impressas e as rádios. (...) o

\footnotetext{
118 SALOMON, M. Filhos põem vida familiar de Lula e Marisa em site. Folha de S.Paulo, 27 de outubro de 2004. Brasil, p. A5. Disponível em:

http: //www1.folha.uol.com.br/fsp/brasil/fc2710200408.htm. Acesso em 23 jun. 2007

119 http://jardinagemlibertaria.wordpress.com/. Acesso em 5 nov. 2008.

120 LAGE, A. Se essa rua fosse minha... Folha de S.Paulo, 25 de setembro de 2008. Equilíbrio. Disponível em: http://www1.folha.uol.com.br/fsp/indices/inde25092008.htm . Acesso em 5 nov. 2008.
} 
jornalista (...) confere um certo protagonismo, em determinados momentos, às personagens de menor força mediática, mas que possivelmente para ele demonstram capacidade de produzir informação tanto como as de maior força" (BERTOCCHI, 2006, p. 4628). Na Polônia, os principais jornais têm adotado o costume de utilizar declarações originalmente veiculadas em blogs para expor o pensamento de pessoas comuns sobre diferentes temas (TRAMMEL et al, 2006).

De artigo publicado por CANAVILHAS (2006, p.12), surge mais um elemento a apontar para uma inter-relação entre blogs independentes e grande imprensa: o fato desses contratarem blogueiros que obtiveram notoriedade na Internet para fazer parte de seus quadros. 0 blog brasileiro Mothern ${ }^{121}$ levou suas duas autoras a serem convidadas a escrever coluna para a revista Trip, da Editora Abril (CANAVILHAS, 2006, p.12); em Portugal, Daniel Oliveira, do blog Barnabé ${ }^{122}$, passou a assinar uma coluna semanal no jornal "Expresso" e virou comentarista de um programa de TV (CANAVILHAS, 2006, p.12); o jornalista Tiago Dória, que edita um blog ${ }^{123}$ sobre cultura digital, tecnologia e mídia, está desde 2005 no portal brasileiro IG.

“Um outro aspecto em que se manifesta nitidamente a complementaridade entre os 'velhos' e os 'novos' meios reside na forma como os blogs inserem, nos seus posts, hiperligações e referências que apontam para os meios de comunicação dominantes" (SERRA, 2006, p. 532). Há uma série de estudos, de diversos países, que confirmam esta tendência. SERRA (2006) apanhou uma relação dos 50 mais importantes blogs formulada por um site português. Excluiu

\footnotetext{
${ }^{121}$ http://mothern.blogspot.com/. Acesso em 5 nov. 2008.

122 http://barnabe.weblog.com.pt/. Acesso em 5 nov.2008.

123 http://www.tiagodoria.ig.com.br/. Acesso em 5 nov. 2008.
} 
22 por tratarem de pornografia ou literatura. Durante uma semana, catalogou todos os posts, contabilizando os links e as referências e distinguindo blogs e outros sites, entre eles, veículos tradicionais de imprensa. Concluiu que $79 \%$ das referências não eram destinadas a blogs, com destaque para dois jornais tradicionais portugueses, Público e Diário de Notícias (SERRA, 2006, p. 542-544). Estudo semelhante foi realizado tendo como corpus 64 mil blogs que publicaram posts sobre os ataques terroristas a Londres, em 2006 (THELWALL, 2006). As fontes mais linkadas foram veículos tradicionais de comunicação: BBC, The New York Times e Guardian. Já MESSNER e DISTASO (2006), partiram da lista de 120 blogs mais populares em 2005 de acordo com o Technorati. Elegendo aleatoriamente um dia diferente para a análise de cada blog, concluíram que 43\% dos links inseridos ao longo dos posts referiam-se a sites da mídia tradicional, além de $10 \%$ destinados a outros sites de notícias. Só $20 \%$ apontavam para outros blogs. MURLEY e ROBERTS (2005), por sua vez, tomaram como base os 20 blogs de maior audiência em abril de 2005, de acordo com o site Truth Laid Bear, e coletaram, durante três dias, todos os seus posts. Concluíram que $49 \%$ das entradas continham ao menos um link para veículos da grande imprensa $-72 \%$ destes links enviavam o internauta a reportagens, e não a textos opinativos. Analisando os blogs que trataram da Guerra do Iraque, um artigo americano apresenta números bastante parecidos. Após processos de filtragem, foram tabulados 899 posts de 79 blogs que abordaram o tema entre 2002 e 2004, e concluiu-se que $50 \%$ dos links fornecidos pelos blogs tinham como destino páginas de empresas tradicionais de comunicação (TREMAYNE et al, 2007). 
MESSNER e DISTASO (2006) apontam, também, para o que denominaram um “ciclo de realimentação" entre blogs e imprensa tradicional, especialmente quando se trata de assuntos políticos. "A mídia tradicional produz reportagens que chegam ao público. Os blogs usam essas reportagens como fonte e tornamnas salientes, criam um buxixo" (MESSNER e DISTASO, 2006), que por vezes gera desdobramentos do fato, que podem ser repercutidos pela imprensa.

Há ainda estudos que procuraram especificamente determinar a capacidade dos blogs de influenciar a agenda dos veículos mais tradicionais de comunicação. Analisando nove blogs espanhóis não-temáticos durante um mês em 2004, OROSA e GARCÍA (2004) concluíram que mais de $87 \%$ dos temas abordados reproduziam assuntos já tratados antes pelos principais jornais do país. Nos EUA, HARPER (2005) concluiu que "por vezes, blogs estabelecem agendas. Entretanto, na maior parte das vezes, reagem a agendas estabelecidas pela grande imprensa ou por aqueles que criam ou fazem as notícias, como os políticos” (HARPER, 2005, p. 22). O impacto maior dos blogs se daria, segundo o pesquisador, no enfoque dos temas que geram grande debate na sociedade (2005, p. 22). A observação de HARPER é semelhante à conclusão de um outro estudo, coordenado por CORNFIELD e CARSON (2004). O argumento destes é que blogs potencializam a discussão de temas colocados pela grande imprensa ou por políticos, mas não têm força para, sozinhos, determinarem agendas. Entretanto, quando muitos dos blogs adotam um enfoque semelhante para um assunto, criam um "buxixo", que é percebido pela grande imprensa e pelos políticos que, em geral, também participam das discussões (p. 30-31). Na mesma linha dos estudos já 
mencionados, MURLEY e ROBERTS (2005) cunham uma expressão que pode ser útil para entender o fenômeno: para eles, os blogs representam um "segundo nível de agenda setting". "A falta de reportagem original e a dependência de comentários contribuem para o segundo nível de agenda setting dos blogs, que geralmente nos dizem o que pensar sobre assuntos que outros haviam nos dito para pensar" (MURLEY e ROBERTS, 2005).

A evolução previsível das relações entre meios tradicionais e weblogs passará seguramente por assumir que no novo cenário comunicativo meios e blogs estão chamados a conviver, que têm funções complementares e que ambas partes têm que aprofundar as características que definem sua própria identidade, em vez de tentar travestir-se: os meios tradicionais têm dificuldades objetivas para fazerem autênticos blogs -e não é o que se espera deles- e os blogs, a menos que sejam de jornalistas, não fazem jornalismo profissional -não é sua função e não estão preparados para fazê-lo (ORIHUELA, 2006, p. 158). 


\section{Capítulo 4 - Os procedimentos analíticos}

\section{1) A primeira análise de conteúdo: os blogs na mídia de texto}

A primeira das duas análises de conteúdo efetivadas para este trabalho consistiu, basicamente, da monitoração dos principais jornais (Folha de S.Paulo e O Globo), revistas (Veja e Época) e portais brasileiros (UOL, Terra e IG) nos dois meses que antecederam o primeiro turno das eleições presidenciais de 2006. A partir da leitura meticulosa das 124 edições dos jornais, 18 de revistas e 372 versões dos portais, foram preenchidas tabelas específicas para cada categoria de veículo. Os principais resultados serão apresentados a seguir.

\subsection{1) As revistas e os blogs}

Tabela 4 - Os blogs nas revistas

\begin{tabular}{|l|c|c|c|c|}
\hline Revista & Edições & Páginas* & Textos** & Citações a blogs \\
\hline Época & 9 & 122 & 28 & 3 \\
\hline Veja & 9 & 113 & 49 & 3 \\
\hline
\end{tabular}

*Número de páginas dedicadas, na soma de todas as edições analisadas, a assuntos relacionados à campanha presidencial; **Número de textos dedicados, na soma de todas as edições analisadas, a assuntos relacionados à campanha presidencial.

Como demonstra a tabela 4, as revistas pouco citaram blogs nas 235 páginas sobre a campanha para a eleição presidencial que, juntas, publicaram nas 18 edições que foram às bancas entre $1^{\circ}$ de agosto e $1^{\circ}$ de outubro de 2006 . Veja e Época dispensaram tratamento bastante semelhante à ferramenta em sua versão impressa: além de terem se referido a blogs em três oportunidades cada, ambas mencionaram apenas dois blogs -nenhum deles produzido por cidadãos 
desconhecidos do grande público. Veja citou duas vezes o blog do jornalista Reinaldo Azevedo ${ }^{124}$, hospedado no site da revista, ambas para divulgá-lo, e uma vez o blog de José Dirceu (utilizado como uma das bases para texto do colunista Diogo Mainardi). Já Época mencionou duas vezes, na mesma edição, da semana de 25 de setembro, o blog ${ }^{125}$ que a revista mantém na Internet -para referir-se a episódio relatado no próximo parágrafo-, uma vez em reportagem, outra em editorial, e também fez uma referência ao blog de José Dirceu, que foi fonte suplementar -ou seja, não fundamental-, para uma reportagem.

Vale menção o fato de Época ter optado por divulgar em seu blog uma nota informando que repórter da revista foi procurado pelos petistas Oswaldo Bargas e Jorge Lorenzetti, interessados em repassar informações de um suposto dossiê com denúncias contra o então candidato ao governo de São Paulo, José Serra, do PSDB. O post informava que Bargas teria dito que o presidente do PT, Ricardo Berzoini, coordenador da campanha de Lula à reeleição, havia sido avisado do encontro com o repórter. Como desdobramento da nota publicada no blog -logo repercutida pelos principais veículos informativos-, Berzoini afastou-se da campanha petista.

\footnotetext{
124 http://veja.abril.com.br/blogs/reinaldo/. Acesso em 25 jun. 2007.

125 http://www.blogbrasil.globolog.com.br/. Acesso em 26 set.2008.
} 


\subsection{2) Os jornais e os blogs}

Tabela 5 - Os blogs nos jornais

\begin{tabular}{|l|c|c|l|c|l|l|}
\hline Veículo & Edições & $\begin{array}{l}\text { Número } \\
\text { de abres } \\
\text { de página* }\end{array}$ & $\begin{array}{l}\text { Número } \\
\text { de } \\
\text { textos* }\end{array}$ & $\begin{array}{l}\text { Citações a } \\
\text { blogs nos } \\
\text { textos }\end{array}$ & $\begin{array}{l}\text { Citações a } \\
\text { blogs na } \\
\text { coluna } \\
\text { específica** }\end{array}$ & $\begin{array}{l}\text { Total } \\
\text { de } \\
\text { citações } \\
\text { a blogs }\end{array}$ \\
\hline Folha & 62 & 358 & 1.093 & 13 & 43 & 56 \\
\hline O Globo & 62 & 410 & 1.001 & 13 & 9 & 22 \\
\hline
\end{tabular}

*Relacionados à campanha presidencial;

**A Folha publicou a coluna "Toda Mídia", que aborda destaques da Internet e televisão, seis vezes por semana durante o período analisado; já O Globo veiculou sem periodicidade definida a coluna "Caiu na rede", para versar sobre temas encontrados na Internet. Em ambos os casos, foram consideradas apenas as citações a blogs referentes a assuntos relacionados à campanha presidencial.

Como o volume da amostra nos jornais é bastante superior àquele das revistas, o número de citações a blogs e seu uso, tanto na Folha de S.Paulo quanto em 0 Globo, são também maiores e mais significativos, como mostra a tabela 5. Ambos citaram blogs 13 vezes cada um em reportagens, colunas, infográficos e textos noticiosos. Na Folha, quatro citações a blogs vieram em reportagens investigativas, quatro em textos noticiosos (que relatavam fatos do dia anterior), outras quatro no Painel da Folha (coluna de notas de bastidor) e uma em artigo de colunista do jornal (ver tabela 6). Já em 0 Globo, três das citações a blogs apareceram em reportagens investigativas, uma em um infográfico de página inteira sobre a chamada “crise do dossiê", duas em textos noticiosos e sete em colunas de seus articulistas (ver tabela 7). Tomando as tabelas 6 e 7 como base, pode-se dizer que o caso em que um blog obteve mais destaque na cobertura dos jornais deu-se no dia 12 de agosto, quando a reportagem “Dirceu ataca globo e 'elite', mas poupa Lula”, alçada a abre de página, trouxe, já na linha fina, “ex-ministro diz em blog que...”. 
Tabela 6 - As citações a blogs nos textos da Folha de S.Paulo*

\begin{tabular}{|c|c|c|c|}
\hline Tipo de texto & Blog citado & Destaque $^{* *}$ & Relevância*** \\
\hline Notícia $^{126}$ & Blog do Zé Dirceu & Sub & Fonte suplementar \\
\hline Coluna $^{127}$ & Blog de Alckmin ${ }^{128}$ & Página 2 & Fonte suplementar \\
\hline Notícia $^{129}$ & Blog do Zé Dirceu & Abre de página & Base principal \\
\hline Notícia $^{130}$ & Blog do Zé Dirceu & Sub & Fonte suplementar \\
\hline Nota de bastidor ${ }^{131}$ & Blog do Zé Dirceu & Painel & Uma das bases \\
\hline Nota de bastidor $^{132}$ & Blog do Zé Dirceu & Painel & Tema \\
\hline Notícia $^{133}$ & Blog do Zé Dirceu & Sub & Fonte suplementar \\
\hline Nota de bastidor ${ }^{134}$ & Blog do Zé Dirceu & Painel & Tema \\
\hline Reportagem $^{135}$ & Blog do Zé Dirceu & Abre de página & Fonte suplementar \\
\hline Reportagem $^{136}$ & Blog do Noblat & Sub & Base principal \\
\hline Reportagem $^{137}$ & Blog do Zé Dirceu & Sub & Uma das bases \\
\hline Nota de bastidor ${ }^{138}$ & Cid Benjamin $^{139}$ & Painel & Tema \\
\hline Reportagem $^{140}$ & Cláudio Humberto $^{141}$ & Sub & Uma das bases \\
\hline
\end{tabular}

*Não estão computadas as citações em colunas específicas; **destaque do texto na página do jornal; *** relevância do blog para a construção do texto.

126 "Dirceu critica intenção do presidente". Disponível em:

http://www1.folha.uol.com.br/fsp/brasil/fc0408200606.htm. Acesso em 5 nov. 2008.

127 “Platitudes no Planalto". Disponível em: http://www1.folha.uol.com.br/fsp/opiniao/fz0108200605.htm.

128 http://www.geraldo45.org.br/blog/index.php. Blog oficial do candidato. Acesso em 10 ago. 2006.

129 "Dirceu ataca Globo e 'elite', mas poupa Lula”. Disponível em:

http://www1.folha.uol.com.br/fsp/brasil/fc1208200613.htm.

130 "Bonner diz que JN tratou petista como os demais". Disponível em:

http://www1.folha.uol.com.br/fsp/brasil/fc1208200616.htm.

131 “Tiroteio". Disponível em: http://www1.folha.uol.com.br/fsp/brasil/fc1308200601.htm.

132 “Repaginado". Disponível em: http://www1.folha.uol.com.br/fsp/brasil/fc3108200601.htm.

133 "Petistas ironizam críticas de tucano a Lula e ao partido". Disponível em:

http://www1.folha.uol.com.br/fsp/brasil/fc0909200606.htm.

134 “Premonição 1". Disponível em: http://www1.folha.uol.com.br/fsp/brasil/fc1609200601.htm.

135 "República de sindicalistas de Lula forjou laços na CUT". Disponível em:

http://www1.folha.uol.com.br/fsp/brasil/fc2009200605.htm.

136 "PF suspeita de diretor do BB na compra do dossiê". Disponível em:

http://www1.folha.uol.com.br/fsp/brasil/fc2009200624.htm.

137 "Caso IstoÉ já gera suspeitas entre petistas". Disponível em:

http://www1.folha.uol.com.br/fsp/brasil/fc2009200631.htm.

138 "Pela boca". Disponível em: http://www1.folha.uol.com.br/fsp/brasil/fc2209200601.htm.

139 http://blogdocidbenjamin.zip.net., atualizado pelo jornalista e candidato derrotado à Assembléia Estadual do RJ em 2006. Acesso em 25 jun. 2007.

140 "Equipe tucana chega antes à sede da polícia". Disponível em:

http://www1.folha.uol.com.br/fsp/brasil/fc2309200623.htm.

${ }^{141}$ http://www.claudiohumberto.com.br/, do jornalista Cláudio Humberto. Acesso em 25 jun. 2007. 
Tabela 7 - As citações a blogs nos textos de 0 Globo*

\begin{tabular}{|c|c|c|c|}
\hline Tipo de texto & Blog citado & Destaque** $^{* *}$ & Relevância*** \\
\hline Nota em coluna $^{142}$ & Blog do Noblat & Sub & Tema \\
\hline Nota em coluna $^{143}$ & Blog do Zé Dirceu & Sub & Tema \\
\hline Nota em coluna $^{144}$ & Blog do Zé Dirceu & Sub & Tema \\
\hline Notícia $^{145}$ & Roberto Jefferson $^{146}$ & Sub & Tema \\
\hline Coluna $^{147}$ & César Rocha ${ }^{148}$ & Abre de página & Fonte suplementar \\
\hline Coluna $^{149}$ & Blog do Zé Dirceu & Abre de página & Fonte suplementar \\
\hline Reportagem $^{150}$ & Blog do Noblat & Abre de página & Fonte suplementar \\
\hline Notícia $^{151}$ & Blog de Emir Sader ${ }^{152}$ & Sub & Uma das bases \\
\hline Infográfico ${ }^{153}$ & Blog do Noblat & Abre de página & Fonte suplementar \\
\hline Coluna $^{154}$ & Cid Benjamin & Abre de página & Uma das bases \\
\hline Coluna $^{155}$ & Blog do Zé Dirceu & Abre de página & Uma das bases \\
\hline Reportagem $^{156}$ & Blog do Zé Dirceu & Abre de página & Uma das bases \\
\hline Reportagem $^{157}$ & Blog do Noblat & Abre de página & Fonte suplementar \\
\hline
\end{tabular}

*Não estão computadas as citações em colunas específicas; **destaque do texto na página do jornal; ***relevância

Um aspecto a se ressaltar é o impacto da “crise do dossiê" nas menções a blogs. Na Folha, 6 das 13 citações aparecem após a prisão, em 15 de setembro, pela Polícia Federal dos petistas Gedimar Passos e Valdebran Padilha com R\$1,7 milhão que seriam usados para a compra de um suposto dossiê contra José Serra. Em 0 Globo, 8 das 13 menções a blogs aconteceram nas duas semanas que antecederam o primeiro turno das eleições presidenciais. Em suma, 14 das 26

\footnotetext{
142 Coluna de Jorge Bastos Moreno de 12 ago. 2006. Título: "Ouro puro".

${ }^{143}$ Coluna de Jorge Bastos Moreno de 12 ago. 2006. Título: "Codinome é com Zé”.

${ }^{144}$ Coluna de llimar Franco de 14 ago. 2006. Título: "Relato".

145 “Roberto Jefferson imita José Dirceu e lança blog”, publicada em 16 ago.2006.

146 http: / /blogdojefferson.com/index.aspx. Acesso em 25 jun. 2007.

147 Coluna de Tereza Cruvinel de 26 ago. 2006.

148 http:/ / www.blogdafolha.com.br/, atualizado pelo jornalista César Rocha. Acesso em 25 jun. 2007.

149 Coluna de Merval Pereira de 19 set. 2006.

150 "O escândalo e os amigos do presidente", publicada em 21 set. 2006.

151 “Tema vira discussão na Internet”, publicada em 26 set. 2006.

152 http://www.cartamaior.com.br/templates/blogMostrar.cfm?blog_id=1\&alterarHomeAtual=1, atualizado pelo sociólogo Emir Sader. Acesso em 25 jun. 2007.

153 "O passo-a-passo do escândalo", publicado em 27 set. 2006.

154 Coluna de Merval Pereira de 23 set. 2006.

155 Coluna de Merval Pereira de 23 set. 2006.

156 "A inteligência do PT", publicada em 24 set. 2006.

157 “Alckmin, entre a meditação e o esforço para subir 1, 2, 3", publicada em $1^{\circ}$ out. 2006.
} 
citações a blogs aconteceram nos 15 dias finais da campanha -13 delas relacionadas ao episódio que dominou amplamente o noticiário dos veículos tradicionais de comunicação. Também nesse período, 0 Globo e Folha referendaram, dando os devidos créditos em reportagens, o único “furo" que reconheceram de um blogueiro durante os dois meses de análise -em ambos os casos, o do jornalista Ricardo Noblat, primeiro a revelar que Expedito Veloso, executivo do Banco do Brasil, estava relacionado à compra do suposto dossiê para prejudicar adversários do presidente Lula nas eleições.

O fato não parece decorrer de coincidência: os dois jornais, assim como os principais veículos de mídia do país, dedicaram ao que denominaram "escândalo do dossiê" grande espaço em suas páginas e efetivaram enormes esforços para desvendar tanto o passado dos personagens principais -alguns deles ligados ao presidente Lula- quanto os bastidores do caso, alçando a fato de grande repercussão cada novo detalhe que conseguissem levantar. Neste contexto, informações veiculadas por blogs de jornalistas e políticos, que em outros momentos talvez passassem despercebidas pelas redações, foram inseridas no amplo material supostamente investigativo publicado por 0 Globo e Folha de S.Paulo.

Contabilizando-se também os textos publicados em colunas específicas, 0 número total de citações a blogs cresce, principalmente na Folha. Na coluna “Toda Mídia”, destinada a abordar a cobertura de veículos de outras plataformas e produzida pelo jornalista Nélson de Sá, foram outras 43 menções a blogs. Ou seja, no total, a Folha citou em 56 ocasiões blogs durante os dois meses de 
análise em seus cadernos de política e eleições (publicado esporadicamente). Já O Globo, com outras nove citações a blogs na coluna "Caiu na rede", veiculada aleatoriamente, sem periodicidade definida, para destacar aspectos interessantes da Internet, chegou a um total de 22. Na Folha, foram 19 os blogueiros referenciados e, em O Globo, 12.

Nas matérias, editoriais e artigos publicados -retirando, portanto, as colunas específicas para acompanhamento da Internet-, os jornais citaram apenas blogs editados por políticos conhecidos ou jornalistas consagrados. A única exceção foi a menção de 0 Globo ao sociólogo Emir Sader, autor de mais de 700 artigos publicados em veículos de imprensa do país ${ }^{158}$, reproduzindo críticas que ele fez em seu blog à cobertura da imprensa. José Dirceu dominou amplamente as citações ao longo dos textos dos jornais: na Folha, 9 das 13 menções a blogs foram ao do ex-ministro da Casa Civil; em o Globo, 5 das 13 citações. Em outras palavras, metade das vezes em que os dois jornais referiram-se a blogs em seus textos sobre a campanha presidencial foi para fazer alusão à página de Dirceu. Quando se somam aos textos as citações a blogs em colunas específicas, o predomínio do petista é atenuado, e alguns blogs produzidos por cidadãos de outras profissões são mencionados (ver tabelas 8 e 9). Entretanto, além de José Dirceu, todos os blogueiros referenciados mais de uma vez no cômputo geral dos textos das duas publicações são jornalistas de renome. De todos os blogs mencionados, apenas três, Bué de Bocas, Mascavinhas e Mulheres de Olho, eram assinados por pessoas desconhecidas do grande público -as três citações

\footnotetext{
158 De acordo com o currículo de Emir Sader na plataforma Lattes, disponível em:
} http://buscatextual.cnpq.br/buscatextual/visualizacv.jsp?id=K4786999Y2. Acesso em 6 nov. 2008 
apareceram em colunas específicas. Todos os outros blogs pertencem a grandes empresas de comunicação, a jornalistas que trabalham para elas ou a pessoas com alguma projeção junto ao público em geral. Ou seja, nos jornais, das 78 citações a blogs, 75 se referiram a páginas editadas por cidadãos que gozam de notoriedade offline ou a herdam dos veículos que lhes dão emprego.

Ainda que não tenha sido incluído na análise por atualmente não publicar um blog, outro político bastante célebre, o então prefeito do Rio de Janeiro, César Maia, foi mencionado oito vezes (seis por O Globo, duas pela Folha) em assuntos relacionados à campanha presidencial devido a seu "ex-blog" -como resolveu denominar um boletim informativo que passou a divulgar aos leitores de seu blog quando resolveu extingui-lo. As oito menções repercutiam comentários escritos e distribuídos por Maia sobre a sucessão presidencial. 
Tabela 8 - Os blogs citados pela Folha de S.Paulo

\begin{tabular}{|c|c|c|}
\hline Nome do blog & Citações & Profissão do autor/natureza do blog \\
\hline Blog do Josias & 11 & Jornalista vinculado ao Grupo Folha \\
\hline Blog do Zé Dirceu & 11 & Político \\
\hline Blog do Noblat & 10 & Jornalista vinculado ao Grupo Estado \\
\hline Fernando Rodrigues & 6 & Jornalista vinculado ao Grupo Folha \\
\hline Blog do Moreno ${ }^{159}$ & 4 & Jornalista vinculado ao Grupo Globo \\
\hline Política \& Cia. ${ }^{160}$ & 1 & Jornalista vinculado ao NoMínimo \\
\hline Blog de Alckmin & 1 & Oficial (de candidato) \\
\hline Blog do Tas ${ }^{161}$ & 1 & Jornalista vinculado ao Grupo Folha \\
\hline Blog de Roberto Jefferson & 1 & Político \\
\hline Bué de Bocas ${ }^{162}$ & 1 & Desconhecido $^{163}$ \\
\hline 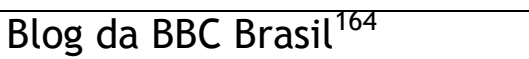 & 1 & Coletivo/Veículo de comunicação \\
\hline Reinaldo Azevedo & 1 & Jornalista vinculado à revista Veja \\
\hline Blog da Caravana $\mathrm{JN}^{165}$ & 1 & Coletivo/Veículo de comunicação \\
\hline Blog Brasil ${ }^{166}$ & 1 & Coletivo/Veículo de comunicação \\
\hline Blog do Luís Nassif ${ }^{167}$ & 1 & Jornalista vinculado ao Grupo Folha \\
\hline Cláudio Humberto & 1 & Jornalista independente \\
\hline Blog Passport $^{168}$ & 1 & Coletivo/Veículo de comunicação \\
\hline Blog do Consultor Jurídico ${ }^{169}$ & 1 & Coletivo/Veículo de comunicação \\
\hline Blog do Cid Benjamin & 1 & Jornalista independente/político \\
\hline
\end{tabular}

\footnotetext{
${ }^{159} \mathrm{http}$ //oglobo.globo.com/pais/moreno/, atualizado pelo jornalista Jorge Bastos Moreno. Acesso em 25 jun. 2007.

${ }_{160}$ http: //politicaecia.nominimo.com.br/, atualizado pelo jornalista Guilherme Fiúza, que tem na carreira passagens como repórter e editor por Jornal do Brasil e 0 Globo.

${ }^{161}$ http://marcelotas.blog.uol.com.br/, atualizado pelo jornalista Marcelo Tas. Acesso em 25 jun. 2007.

162 http://www.nelsonperez.blogspot.com/, atualizado por Nelson Perez. Acesso em 25 jun. 2007.

163 Em seu blog, Nelson Perez afirma ter 55 anos, mas não revela sua profissão.

164 http://www.bbc.co.uk/blogs/portuguese, atualizado pela equipe de jornalistas da empresa. Acesso em 10 out. 2006.

${ }^{165}$ http: / / jornalnacional.globo.com/Jornalismo/JN/0, ,7040,00.html, atualizado por jornalistas da TV Globo. Acesso em 25 jun. 2007.

${ }^{166}$ http: //www.blogbrasil.globolog.com.br/, atualizado por jornalistas da Revista Época. Acesso em 25 jun. 2007.

${ }^{167}$ http: //luisnassifonline.blog.uol.com.br/, atualizado pelo jornalista Luis Nassif. Acesso em 25 jun. 2007. A partir de 26 de setembro de 2006, Nassif passou a escrever para o IG, no endereço http: / / luisnassif.blig.ig.com.br/, acessado em 25 jun. 2007.

168 http://blog.foreignpolicy.com/, atualizado por repórteres da revista Foreign Policy. Acesso: 25 jun. 2007.

169 http://blog.estadao.com.br/blog/eleicoes2006/, atualizado pelos jornalistas do site Consultor Jurídico. Acesso em 25 jun. 2007.
} 
Tabela 9: Os blogs citados por O Globo

\begin{tabular}{|c|c|c|}
\hline Nome do blog & Citações & Profissão do autor/natureza do blog \\
\hline Blog do Zé Dirceu & 7 & Político \\
\hline Blog do Noblat & 5 & Jornalista vinculado ao Grupo Estado \\
\hline Blog do Emir Sader & 1 & Sociólogo \\
\hline Blog do César Rocha & 1 & Jornalista da Folha de Pernambuco \\
\hline Blog Mulheres de Olho ${ }^{170}$ & 1 & Coletivo/institucional \\
\hline Blog do Mascavinhas $^{171}$ & 1 & Anônimo/desconhecido \\
\hline Blog do Cid Benjamin ${ }^{172}$ & 1 & Jornalista independente/político \\
\hline Blog do G1 & 1 & Coletivo/veicúlo de comunicação \\
\hline Blog do Alckmin ${ }^{1 / 3}$ & 1 & Oficial (de candidato) \\
\hline Blog de Roberto Jefferson ${ }^{1 / 4}$ & 1 & Político \\
\hline Fernando Rodrigues & 1 & Jornalista vinculado ao Grupo Folha \\
\hline Blog do Moreno & 1 & Jornalista vinculado ao Grupo Globo \\
\hline
\end{tabular}

\section{3) Os portais e os blogs}

Segundo portal mais visitado do Brasil no período analisado, o Terra não veiculou chamadas para blogs em sua cobertura da campanha presidencial, nem na página principal, nem no canal específico para as eleições, ao menos nos horários em que a pesquisa foi realizada (sempre entre $18 \mathrm{~h} 45$ e 19h30). Já o UOL, líder de audiência no período, deu 33 chamadas para blogs -nove delas de capa, inclusive uma que chegou à manchete do site-, referentes a 31 posts. Em sua página inicial, o portal abordou a sucessão presidencial 100 vezes no período (ver tabela 10), o que permite concluir que $9 \%$ dos links sobre o assunto tinham blogs como destino. No canal de "Eleições", o UOL veiculou, nos momentos em

\footnotetext{
170 http://www.mulheresdeolho.org.br/, atualizado por integrantes do Instituto Patrícia Galvão Comunicação e Mídia, que luta pelo direito das mulheres. Acesso em 25 jun. 2007.

171 http://novomascavinhas.zip.net/, atualizado por um blogueiro que se intitula Mascavinhas, mas não fornece em seu blog nome nem profissão. Acesso em 25 jun. 2007.

172 http://blogdocidbenjamin.zip.net., atualizado pelo jornalista e candidato derrotado à Assembléia Estadual do RJ em 2006. Acesso em 25 jun. 2007.

${ }^{173} \mathrm{http}: / /$ www.geraldo45.org.br/blog/index.php. Blog oficial do candidato. Acesso em 10 ago. 2006.

174 http://blogdojefferson.com/index.aspx. Acesso em 25 jun. 2007.
} 
que foi analisado, 412 chamadas que abordaram as eleições presidenciais (ver tabela 11). Delas, 5,8\%, ou um total de 24, foram para blogs. Em 32 dos 62 dias, o portal não destinou chamadas a esse tipo de site para tratar da campanha presidencial.

Tabela 10 - A primeira página dos portais e os blogs

\begin{tabular}{|l|c|c|c|c|c|}
\hline Portal & Chamadas* & $\begin{array}{l}\text { Chamadas } \\
\text { para blogs* }\end{array}$ & $\begin{array}{l}\text { Manchetes } \\
\text { para blogs* }\end{array}$ & $\begin{array}{l}\text { Blocos } \\
\text { temáticos } \\
\text { (eleições) }\end{array}$ & $\begin{array}{l}\text { Blocos } \\
\text { temáticos } \\
\text { para blogs }\end{array}$ \\
\hline UOL & 100 & $9(9 \%)$ & 1 & 0 & 1 \\
\hline IG & 154 & $68(44 \%)$ & 0 & 62 & 44 \\
\hline
\end{tabular}

*Com assuntos relacionados à campanha presidencial

Tabela 11 - 0 canal de Eleições dos portais e os blogs

\begin{tabular}{|l|c|c|c|}
\hline Portal & Chamadas* $^{*}$ & Chamadas para blogs* & Manchetes para blogs* \\
\hline UOL & 412 & $24(5,8 \%)$ & 1 \\
\hline IG & 245 & $13(5,3 \%)$ & 0 \\
\hline
\end{tabular}

${ }^{*}$ Com assuntos relacionados à campanha presidencial

O IG, terceiro colocado em audiência, foi quem mais destaque concedeu aos blogs em sua cobertura. Adotando durante o período em sua página inicial um design gráfico com abas que permitiam a visualização rápida de sete canais além do denominado "Principal", o IG colocou, entre estes sete, um específico para “Eleições” e outro destinado para “Blogs - Opinião", que tratava de assuntos diversos -inclusive política. No total, o site veiculou 81 chamadas, frutos de 77 posts de blogueiros sobre a sucessão presidencial. Em 46 dos 62 dias (74,2\%) do 
período, o IG tinha blogs versando sobre o tema em um dos três espaços (“Principal”, “Eleições” e “Blogs - Opinião”). Seis das 81 chamadas para blogs apareceram na capa; 13 estiveram em “Eleições” e 62 no espaço específico dedicado à blogosfera.

Tabela 12 - Os portais e o tipo de conteúdo do blog destacado

\begin{tabular}{|l|c|c|}
\hline \multicolumn{1}{|c|}{ Natureza do post } & UOL & IG \\
\hline Notícia & $7(22,6 \%)$ & $16(20,8 \%)$ \\
\hline Notícia em primeira-mão & $12(38,7 \%)$ & $7(9,1 \%)$ \\
\hline Furo & 0 & $1(1,3 \%)$ \\
\hline Comentário/análise & $11(35,5 \%)$ & $49(63,6 \%)$ \\
\hline Humor & 0 & $4(5,2 \%)$ \\
\hline Enquete & $1(3,2 \%)$ & 0 \\
\hline Total de posts destacados & 31 & $\mathbf{7 7}$ \\
\hline
\end{tabular}

Quanto à característica predominante em cada post destacado, os dois portais demonstraram lógicas aparentemente distintas. Enquanto no IG 63,6\% dos “posts" que mereceram chamadas (49 de 77) consistiam de comentários ou análises, no UOL 35,5\% dos posts em destaque (11 de 31) foram para textos do gênero. O portal líder em audiência no período lançou mão dos blogs eminentemente para dar notícias, em “primeira mão” (12) -em relação à concorrência- ou não (7). Ou seja, dos 31 "posts" de blogs veiculados em chamadas editoriais pelo UOL, 19 , ou $61,3 \%$, tinham caráter predominantemente noticioso. No IG, esse percentual foi de 31,2\%: 1 furo, 16 notícias "em primeira mão" e outros sete posts noticiosos, em um total de 24 dos 77 posts. 
Tabela 13 - Os blogs destacados pelo IG

\begin{tabular}{|c|c|c|}
\hline Nome do blog & Posts destacados & Profissão do autor/natureza do blog \\
\hline Blog do Zé Dirceu ${ }^{1 / 5}$ & 24 & Político \\
\hline Blog do $\mathrm{ET}^{176}$ & 19 & Jornalista vinculado ao IG \\
\hline Blog do Tão ${ }^{177}$ & 13 & Jornalista vinculado ao IG \\
\hline Ponte Aérea SP ${ }^{1 / 8}$ & 6 & Jornalista vinculado ao NoMínimo \\
\hline Política \& Cia. & 7 & Jornalista vinculado ao NoMínimo \\
\hline Politiquês ${ }^{179}$ & 2 & Jornalista vinculado ao IG \\
\hline Luís Nassif $^{180}$ & 2 & Jornalista vinculado ao IG \\
\hline Mino Carta ${ }^{181}$ & 2 & Jornalista vinculado ao IG \\
\hline Em cima da mídia ${ }^{182}$ & 1 & Jornalista do Observatório de Imprensa \\
\hline Verbo solto $^{183}$ & 1 & Jornalista do Observatório de Imprensa \\
\hline Olha só ${ }^{184}$ & 1 & Jornalista vinculado ao NoMínimo \\
\hline Non sense $^{185}$ & 1 & Jornalista vinculado ao NoMínimo \\
\hline
\end{tabular}

Tabela 14 - Os blogs destacados pelo UOL

\begin{tabular}{|l|c|l|}
\hline Nome do blog & Posts destacados & Profissão do autor/natureza do blog \\
\hline Blog do Josias & 18 & Jornalista vinculado ao Grupo Folha \\
\hline Fernando Rodrigues & 7 & Jornalista vinculado ao Grupo Folha \\
\hline Blog do Nassif & 3 & Jornalista vinculado ao Grupo Folha \\
\hline Blog do Tas & 2 & Jornalista vinculado ao Grupo Folha \\
\hline Blog do JC & 186 & Jornalista do Jornal do Commercio \\
\hline
\end{tabular}

\footnotetext{
175 O blog de José Dirceu começou a ser publicado em 7 ago. 2006.

${ }^{176} \mathrm{http}$ ://blogdoet.blig.ig.com.br/, atualizado pelo jornalista Etevaldo Dias. Acesso em 25 jun. 2007. 0 blog foi lançado pelo IG no dia $1^{\circ}$ ago. 2007.

177 http://taogomespinto.blig.ig.com.br/, atualizado pelo jornalista Tão Gomes Pinto. Acesso em 25 jun. 2007.

${ }^{178}$ http: //ponteaereasp.nominimo.com.br/, atualizado pelo jornalista Xico Sá. Acesso em 25 jun. 2007.

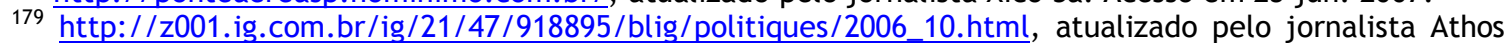
Sampaio. Acesso em 25 jun. 2007.

$180 \mathrm{O}$ blog de Luis Nassif estreou no IG em 26 set. 2007.

${ }^{181}$ http://blogdomino.blig.ig.com.br/, atualizado pelo jornalista Mino Carta. Acesso em 25 jun. 2007. 0 blog estreou no dia 4 set. 2007.

182 http://observatorio.ultimosegundo.ig.com.br/blogs.asp?id_blog=4, atualizado pelo jornalista Mauro Malin. Acesso em 25 jun. 2007. O blog faz parte do site do Observatório de Imprensa.

183 http://observatorio.ultimosegundo.ig.com.br/blogs.asp?id_blog=3, atualizado pelo jornalista Luiz Weis. Acesso em 25 jun. 2007. O blog faz parte do site do Observatório de Imprensa.

${ }^{184}$ http://olhaso.nominimo.com.br/, atualizado pelo jornalista Ricardo Calil. Acesso em 25 jun. 2007.

185 http://nonsense.nominimo.com.br/, atualizado pelo jornalista Luiz Antonio Ryff. Acesso em 25 jun. 2007.

186 http://jc.uol.com.br/blogs/blogdejamildo/, atualizado pelo jornalista Jamildo Melo. Acesso em 25 jun. 2007.
} 
Apesar de tanto IG quanto UOL oferecerem serviços gratuitos de hospedagem de blogs que contam com milhares de cadastrados e de poderem utilizá-los em suas chamadas editoriais, nenhum dos dois sites optou por dar visibilidade ao conteúdo produzido pelos internautas. Ambos apostaram fortemente nos blogs produzidos por jornalistas -o ex-ministro José Dirceu, que começou a publicar seu blog no IG durante o período desta análise, em 7 de agosto de 2006, e é advogado, foi o único cidadão com outra profissão a ser destacado pelos portais. No UOL, apenas cinco blogs foram alçados à primeira página ou ao canal de eleições -quatro deles eram à época funcionários do Grupo Folha, principal acionista e controlador do portal. 0 outro blog destacado, o do site do diário pernambucano Jornal do Commercio, também pertence à mídia tradicional e que tem parceria comercial com o UOL. Dos 12 blogs destacados pelo IG, 11 eram de jornalistas, 5 dos quais contratados pelo portal; os outros seis blogueiros que tiveram chamadas para seus blogs eram contratados do extinto site NoMínimo, à época parceiro do IG, ou do Observatório de Imprensa, mais famosa entidade de análise e discussão do jornalismo do Brasil.

\section{2) A segunda análise de conteúdo: os quatro blogs mais influentes}

Como era de se esperar, os quatro blogs escolhidos para análise, dos jornalistas Josias de Souza e Fernando Rodrigues (ambos hospedados no portal UOL), do também jornalista Ricardo Noblat (à época alojado no site do jornal 0 Estado de São Paulo) e do ex-ministro José Dirceu, escreveram mais, numérica e 
proporcionalmente, sobre a eleição presidencial no segundo momento de análise, mais próximo do primeiro turno do pleito (ver tabela 15).

Tabela 15 - Número de posts relacionados à campanha presidencial

\begin{tabular}{|l|c|c|}
\hline Autor do blog & Momento 1* $^{*}$ & Momento 2** \\
\hline Josias de Souza & 29 de 65 $(44,4 \%)$ & 43 de $54(79,6 \%)$ \\
\hline Fernando Rodrigues & 6 de $12(50 \%)$ & 12 de $16(75 \%)$ \\
\hline José Dirceu & 26 de $50(52 \%)$ & 61 de $70(87,1 \%)$ \\
\hline Ricardo Noblat & 86 de $208(41,3 \%)$ & 137 de $194(70,6 \%)$ \\
\hline
\end{tabular}

*Momento 1 - semana de 21 a 27 de agosto de 2006;

${ }^{* *}$ Momento 2 - semana de 18 a 24 de setembro de 2006

A análise dos dados quantitativos indica que o mais ativo dos quatro blogueiros, nos períodos englobados pela pesquisa, foi Ricardo Noblat, que teve sua página atualizada intensamente, inclusive às madrugadas. Contando com ao menos dois repórteres exclusivos para o blog, Felipe Racondo e Gustavo Noblat, o blogueiro ainda convidou Lúcia Hippolito, Luciana Pinsky, Tânia Fusco e Valéria Grassi para escrever posts e reuniu um extenso time de colunistas semanais: Ruy Fabiano, Zélia Adghirni, Maria Helena Rubinato Rodrigues de Sousa, Alon Feuerwerker, Bruno Lima Rocha, Almyr Gajardoni, Murillo de Aragão e Vitor Hugo Soares tiveram artigos publicados. No outro extremo, aparece o jornalista Fernando Rodrigues. Na semana de agosto utilizada como campo de pesquisa, os seis posts que versavam sobre a campanha presidencial eram da mesma natureza: uma agenda de eventos políticos com potencial impacto sobre o noticiário. Na semana de setembro, 5 dos 12 posts concernentes ao tema deste 
trabalho possuíam a mesma natureza: previsões do que poderia vir a ocupar as manchetes dos principais veículos.

Uma análise dos elementos constitutivos dos quatro blogs escolhidos para escrutínio mostra que todos utilizavam timidamente boa parte dos recursos que auxiliam os blogs a formarem comunidades, como exposto no item 2.2.2 deste trabalho. Josias de Souza e Fernando Rodrigues forneciam links fixos, na lateral de suas páginas, apenas para blogs e sites dos veículos que os hospedavam. Já José Dirceu e Ricardo Noblat não disponibilizavam ligação para nenhum blog ou site em suas respectivas páginas iniciais. Ou seja, nenhum deles aproveitava o blogroll, um espaço nobre para a troca de referências, para reconhecer “colegas” de blogosfera e ampliar sua visibilidade. Os três jornalistas contavam com feeds de RSS -José Dirceu, não-, mas não adotavam “trackback” nem utilizavam "tags" em seus posts, o que dificulta o estabelecimento de conversações e a indexação de seu conteúdo nos sistemas de busca de blogs.

Além de não aproveitarem mecanismos para permitir a formação de comunidades em torno deles, os quatro blogueiros pouco ou nada "conversaram" com seus leitores (ver tabela 16). Fernando Rodrigues não promoveu qualquer interação com seu público nas duas semanas em que seus posts foram verificados. Josias de Souza respondeu seis vezes a comentários, na área dedicada a eles -nas seis oportunidades, para se defender de acusações deixadas por internautas. José Dirceu, que fez de sua página uma espécie de misto entre clipping de notícias favoráveis aos interesses do governo e espaço para rebater 
críticas da oposição, publicou em uma ocasião um comentário deixado em seu blog pelo policial federal Edisson Tessele.

Tabela 16 - Comentários e interação nos blogs nos dois períodos

\begin{tabular}{|l|c|c|c|c|c|c|}
\hline Blog & Posts & Comentário & $\begin{array}{l}\text { Comentário } \\
\text { por post }\end{array}$ & $\begin{array}{l}\text { Resposta a } \\
\text { comentário }\end{array}$ & $\begin{array}{l}\text { Post de } \\
\text { resposta }\end{array}$ & $\begin{array}{l}\text { Publica } \\
\text { blogueiro }\end{array}$ \\
\hline Josias 1* & 29 & 5216 & 179,8 & 0 & 0 & 0 \\
\hline Josias 2 & 43 & 5817 & 135,2 & 6 & 0 & 0 \\
\hline FR $^{* *} 1$ & 6 & 155 & 25,8 & 0 & 0 & 0 \\
\hline FR 2 & 12 & 1687 & 140,5 & 0 & 0 & 0 \\
\hline Noblat 1 & 86 & 1868 & 21,7 & 0 & 0 & 1 \\
\hline Noblat 2 & 137 & 6530 & 47,6 & 0 & 5 & 1 \\
\hline Dirceu 1 & 26 & 606 & 23,3 & 0 & 0 & 1 \\
\hline Dirceu 2 & 61 & 1947 & 31,9 & 0 & 0 & 0 \\
\hline
\end{tabular}

${ }^{*}$ Os números ao lado dos blogs se referem ao período de análise $\left(1^{\circ}\right.$ ou $\left.2^{\circ}\right)$; ${ }^{* *} \mathrm{FR}$ - Blog do Fernando Rodrigues.

Outras observações: alguns blogs, como é o caso de Josias de Souza (nos dois momentos) e de Ricardo Noblat (no segundo momento de análise), não adotaram moderação nos comentários, ou seja, os leitores publicaram várias vezes o mesmo conteúdo, distorcendo a análise; Em "Posts", estão contabilizados somente os posts que abordam a campanha presidencial; "Resposta a comentário" refere-se à resposta logo abaixo do comentário publicado por leitor; Foi considerado "Post de resposta" aquele que o blogueiro publica citando nominalmente o comentário publicado por internauta ou o nome do leitor; "Publica blogueiro" ocorre quando o autor publica, em um post, conteúdo enviado por leitor;

Noblat destacou-se dos demais por buscar interação -ainda que não tenha de fato efetivado muitas trocas com seu público. Em 21 de agosto, por exemplo, no post "Quem pede votos para quem", convocou leitores do blog a empreenderem uma "apuração coletiva" nos Estados para checar se candidatos da coligação PSDB-PFL pediam votos para o candidato Geraldo Alckmin. No texto, prometeu publicar no mesmo dia um post analisando o resultado. Apesar dos dez comentários recebidos, o post nunca foi veiculado. 0 jornalista chegou a criar uma seção denominada "Calçada da Fama" para responder aos internautas. 
Entretanto, durante os dois períodos de análise, deu respostas a questões deixadas por seu público somente quatro vezes -três delas no dia 24 de setembro. Além disso, também no dia 24 de setembro, publicou um post "em resposta à cobrança de vários leitores”. Em duas ocasiões, uma em cada período de análise, prestou-se a publicar em posts comentários deixados por leitores. Um, em 23 de agosto, dava voz a um leitor que discutia a estratégia de Alckmin. Outro, em 24 de setembro, compartilhava uma piada enviada por um internauta. Além da possibilidade de receber informações, sugestões de pauta e opiniões pertinentes, outra das vantagens da interação com os leitores para os blogueiros é a possibilidade de rápida correção de erros. Tanto Noblat quanto Josias poderiam ter retificado falhas -que perduram até hoje em suas páginas- se tivessem atentado a comentários de leitores. Os dois casos ocorreram em 22 de agosto de 2006. Josias publicou: "Heloísa Helena passa Alckmin em pesquisa feita na Bahia", e leitor alertou corretamente que, ao contrário do que escrevia o jornalista, o levantamento foi restrito a Salvador, e não a todo o Estado. Noblat, por sua vez, errou duas vezes neste dia. Primeiro, afirmou, às 19h50, que "a mais recente pesquisa do Instituto Datafolha trará uma boa notícia para Alckmin. Logo mais no Jornal Nacional a partir das 20h. Aqui, talvez daqui a pouco". A notícia não era boa: enquanto Alckmin havia oscilado um ponto percentual para cima, Lula aparecia com dois pontos a mais do que no levantamento anterior, e a aprovação ao governo havia estabelecido novo recorde. Às 20h05, o jornalista escreveu: “agora, uma má notícia para Alckmin: Lula também cresceu um ponto na pesquisa Datafolha”. Apesar do alerta de internautas de que o petista 
crescera dois pontos (e não um), a informação permaneceu incorreta -e nenhuma errata foi publicada.

A análise dos tipos de sites que mereceram links ao longo dos posts dos quatro blogs mostra que os veículos tradicionais de comunicação foram amplamente dominantes (ver tabela 17). Josias de Souza, o que mais ligações concedeu na soma dos dois períodos, deu 141 links, em uma média de 1,95 por post. Excluindo-se os 17 links para posts anteriores do próprio blog do Josias (o que convencionamos classificar como 'auto-referências'), 82 dos 124 links (ou 66\%) concedidos tiveram como alvo sites (81 casos) ou blogs (um caso) alimentados por empresas jornalísticas tradicionais. Sites de candidatos, de partidos ou do governo receberam 26 atalhos (21\%). Para outros sites, foram seis links. Para blogs independentes, nenhum. Já seu companheiro de Folha de S.Paulo Fernando Rodrigues forneceu apenas um link nas duas semanas de análise -para o site da própria Folha. Ricardo Noblat, que em média deu 0,51 link por post, destinou 27 links para entradas de seu próprio blog. Dos 87 restantes, 79 (91\%) foram para a grande imprensa, um para site de candidato, 3 para páginas de outros tipos. Noblat foi o único entre os quatro a dar link para blogs independentes, ou seja, não-vinculados nem a partidos políticos nem à grande imprensa. Nenhum deles pode ser classificado como "desconhecido": dois dos links foram para o Blog do Alon, de Alon Feuerwerker, ex-vice-presidente do UOL, ex-assessor dos exprefeitos de São Paulo José Serra e Marta Suplicy, e jornalista com passagens pela Agência Folha e Correio Braziliense em cargos de chefia; o blog do jornal "O Povo", o mais vendido do Ceará, e o blog do “Observatório de Imprensa”. José 
Dirceu, por sua vez, deu 1,42 links por post. Excluídos os 18 links autoreferentes, foram 106, no total: 94 (89\%) deles para a grande imprensa, 5 para sites do governo e 7 para outros sites.

Somando-se os quatro blogs e excluindo-se as ligações auto-referentes, apenas 9 dos 318 links (menos de 3\% do total) se destinaram a blogs e, destes, somente $4(1,2 \%)$ para blogueiros independentes. Por outro lado, a grande imprensa foi alvo de 256 links $(80,5 \%$ do total).

Tabela 17 - Tipos de site para os quais blogueiros deram links nos dois momentos

\begin{tabular}{|c|c|c|c|c|c|c|c|c|c|c|c|c|}
\hline & \multicolumn{3}{|c|}{ Josias } & \multicolumn{3}{|c|}{ F. Rodrigues } & \multicolumn{3}{|c|}{ Noblat } & \multicolumn{3}{|c|}{ José Dirceu } \\
\hline Tipo de veículo & $11^{* *}$ & 2 & $\bar{T}$ & 1 & 2 & $T$ & 1 & 2 & $\mathrm{~T}$ & 1 & 2 & $\bar{T}$ \\
\hline Jornal nacional & 7 & 4 & 11 & - & 1 & 1 & 14 & 38 & 52 & 9 & 36 & 45 \\
\hline Jornal local/temático & - & 8 & 8 & - & - & - & 1 & - & 1 & 1 & 8 & 9 \\
\hline Revistas & - & - & - & - & - & - & 1 & - & 1 & - & 5 & 5 \\
\hline Sites (grande impr.* & 13 & 34 & 47 & - & - & - & 8 & 12 & 20 & 2 & 29 & 31 \\
\hline Sites de ONGs & - & 1 & 1 & - & - & - & - & 1 & 1 & - & 1 & 1 \\
\hline Sites do governo & 1 & 2 & 3 & - & - & - & - & - & - & 3 & 2 & 5 \\
\hline Blogs (grande impr.*) & - & 1 & 1 & - & - & - & - & 3 & 3 & - & 1 & 1 \\
\hline Blogs independentes & - & - & - & - & - & - & 4 & - & 4 & - & - & - \\
\hline Auto-referência & 9 & 8 & 17 & - & - & - & 13 & 14 & 27 & 1 & 17 & 18 \\
\hline Agência de notícias & 7 & 8 & 15 & - & - & - & - & 2 & 2 & - & 3 & 3 \\
\hline Outros sites & 7 & 8 & 15 & - & - & - & 2 & - & 2 & 1 & 5 & 6 \\
\hline Site de candidato & 18 & 5 & 23 & - & - & - & 1 & - & 1 & - & - & - \\
\hline Total & 62 & 79 & 141 & - & 1 & 1 & 44 & 70 & 114 & 17 & 107 & 117 \\
\hline
\end{tabular}

*Grande impr. - veículos tradicionais de imprensa (maiores portais brasileiros foram incluídos na relação); 1 - dados relativos ao primeiro período de análise; 2 - dados referentes ao segundo período de análise; T total (soma dos dois períodos) 


\section{Conclusão}

A emergência do novo panorama comunicativo descrito neste trabalho, em que o ciberespaço e, mais especificamente, os blogs, tornam viável uma atividade maior dos cidadãos nos processos informativos e comunicativos, carrega consigo elementos necessários para o desenvolvimento da esfera pública. 0 modelo unidirecional protagonizado pelos meios de comunicação de massa passa a conviver com uma "multiplicidade de espaços públicos que vigoram graças à crescente utilização de novas tecnologias" (RODRIGUES, 2006, p. 22), que podem servir de instrumento para que "públicos subalternos, excluídos do discurso político vigente, através da comunicação virtual, reestruturem o mundo real" (MONTEZ e GAMA, 2006).

Pelo modo de comunicação ciberespacial os atores da sociedade civil desfrutam de maior eqüidade no processo informativo, o que aumenta a possibilidade de construir opiniões públicas com maior liberdade. Assim sendo, o modelo de esfera pública imaginado por Habermas tem chances de reabilitar-se (BRITTES, 2003, p. 163).

Entretanto, a simples existência de ferramentas, como os blogs, a propiciar oportunidades não conduz, necessariamente, a sociedade a adotar de forma generalizada práticas que poderiam significar o estabelecimento de processos de discussão e formação de consensos em relação a questões de interesse público. Como aponta SASSI (2001), "qualquer reflexão acerca da sociedade civil leva à crítica das esperanças” de renovação da democracia. OROSA e GARCÍA (2004) utilizam a noção de campo social de Pierre Bourdieu para apontar que a Internet não configura um sistema independente do existente offline. Para os autores, a 
"pluralidade incensurável” da Internet não é mais do que um desejo (OROSA e GARCÍA, 2004, p. 118).

“O campo obedece não só à lógica do instrumento tecnológico que the serve de base como ao complexo imbricado do mercado de produtores, consumidores, práticas e saberes institucionalizados. No caso do campo informativo, o sistema de transmissão de informação pode alterar o formato semiótico dos conteúdos (audiovisuais, escritos), mas é inocente pensar que por si só altera o jogo de interesses, hierarquias e práticas de todo o campo. (...) É certo que, em seu conjunto, a quantidade de material que a rede abriga é extremamente heterogênea. Mas isto não significa que sobre elas não atuem as forças que no campo informativo configuram um discurso hegemônico nem muito menos que da possibilidade real de mais conteúdos se deduza uma ampliação democrática do meio" (OROSA e GARCÍA, 2004, p. 118-119).

Para BAUMAN (2001), os efeitos do que denomina "modernidade líquida" sobre as pessoas, com os processos vigentes de enfraquecimento dos laços sociais e individualização da sociedade tornam o ser humano cada vez menos um cidadão e inviabilizam os ideais de ampliação da democracia.

"As perspectivas de que os atores individualizados sejam 'reacomodados' no corpo republicano dos cidadãos são nebulosas. 0 que os leva a aventurar-se no palco público não é tanto a busca de causas comuns e de meios de negociar o sentido do bem comum e dos princípios da vida em comum quanto a necessidade desesperada de 'fazer parte da rede'. Compartilhar intimidades (...) tende a ser o método preferido, e talvez o único que resta, de 'construção da comunidade'. (...) Os cuidados e preocupações dos indivíduos enquanto indivíduos enchem o espaço público até o topo, (...) expulsando tudo o mais do discurso público. "O 'público' é colonizado pelo 'privado'; o 'interesse público' é reduzido à curiosidade sobre a vida privada de figuras públicas e a arte da vida pública é reduzida à exposição pública das questões privadas e a confissões de sentimentos privados” (BAUMAN, 2001, p.46).

Os elementos apresentados por esta dissertação corroboram, de certa forma, tanto o pessimismo dos autores apresentados nos parágrafos anteriores quanto a empolgação de outros pensadores citados ao longo do trabalho. 0 potencial do 
novo panorama comunicativo de que os blogs são parte é revolucionário. Por tratar-se de um processo muito recente, ainda em ebulição, em uma época em que novas tecnologias, práticas e configurações se sucedem em velocidade espantosa e afetam as mais diversas áreas da vida humana, conclusões e afirmações peremptórias não soam sensatas. Por outro lado, os dados concretos obtidos pelos procedimentos metodológicos aqui efetuados levam-nos a acreditar que, estritamente no âmbito do universo dos veículos e blogs analisados durante os dois meses que antecederam o primeiro turno da eleição presidencial de 2006 no Brasil induzem ao ceticismo. Os parágrafos seguintes se propõem a enumerar os motivos.

Em um indício de que os blogs já faziam parte do cenário do jornalismo brasileiro durante os dois meses que antecederam a eleição presidencial do Brasil, os maiores jornais e revistas do país citaram blogs e todos eles contavam com blogs em suas versões online. Só o Terra, dos sete veículos sob escrutínio, ignorou o fenômeno. Entretanto, os resultados das duas análises de conteúdo mostram que, em agosto e setembro de 2006, especificamente no universo desta pesquisa, os blogs constituíram-se muito mais em uma ferramenta para que pessoas ou organizações dotadas de credenciais no "mundo real" expressassem suas opiniões ou apresentassem o resultado de seu trabalho em uma nova plataforma do que se configuraram como um mecanismo de ampliação do escopo de participantes ativos nas discussões políticas.

Maiores provedores de acesso a Internet do país, UOL, Terra e IG detêm serviços que hospedam centenas de milhares de blogs. Apesar disso, o IG limitou- 
se a destacar um total de 12 blogs diferentes -contra apenas cinco do UOL. Dos 17 blogs que receberam chamadas nos portais brasileiros no período de análise, 16 são escritos por jornalistas. Todos ostentam credenciais suficientes para serem considerados profissionais consagrados ou estão vinculados a veículos de grande porte e/ou prestígio na comunicação brasileira. 0 único não-jornalista do grupo é ainda mais conhecido do que os demais: José Dirceu. Ou seja, blogs produzidos por anônimos não estiveram em nenhum dos 62 dias analisados nas três principais "vitrines" da Internet nacional, que receberam quatro de cada cinco usuários domiciliares do Brasil em setembro de 2006, de acordo com a pesquisa "Nielsen-NetRatings".

Nas revistas analisadas, os blogs praticamente não marcaram presença. Exceto por menções a blogs vinculados às publicações, apenas a página de José Dirceu foi destacada -como provavelmente seria destacada sua opinião se, em vez de publicá-la em seu blog, enviasse uma nota ou comunicado oficial ao email de jornalistas. Mesmo computando-se as três menções a desconhecidos nos jornais, únicos dos três veículos a dar voz a donos de blogs que não são dotados de prestígio no "mundo real” para transferi-los ao ciberespaço, não se pode considerar que as poucas linhas gastas com os blogs Bué de Bocas, Mascavinhas e Mulheres de Olho em colunas focadas especificamente na tarefa de monitorar a Internet (no caso de O Globo) e também veículos de outras mídias (no caso da Folha) sejam significativos em um universo de 2.094 textos publicados sobre a campanha presidencial nos dois jornais. Parece-nos ainda menos sensato enxergar nestas três menções algum indício de democratização da comunicação. 
Em que pese o fato de que Folha, O Globo, Veja e Época tenham citado blogs, não houve nenhum caso de sinergia entre blogs e grande imprensa, como os relatados no item 3.2.2 deste trabalho, em que uma denúncia ou novas informações introduzidas por blogs tenham pautado a cobertura dos veículos tradicionais e induzido a desdobramentos políticos. Apenas um "furo" de blogueiro acabou referendado nas páginas dos jornais, e o autor é um jornalista consagrado, Ricardo Noblat.

Se os resultados da análise dos principais veículos de texto parecem pouco animadores para os entusiastas dos blogs, os dados da checagem dos quatro blogs de maior visibilidade na imprensa de texto durante agosto e setembro de 2006 não fornecem notícias melhores. A pesquisa indica que nenhum deles adotou princípios fundamentais para que conversações se desenvolvessem na blogosfera. Ricardo Noblat, Fernando Rodrigues, Josias de Souza e José Dirceu interagiram pouquíssimas vezes com seus leitores e, de forma geral, adotaram apenas uma pequena parcela dos mecanismos auxiliares à formação de comunidades, expostos no item 2.2.2 desta dissertação. Além disso, o fato de não concederem links a blogs menos cotados acabou por não ativar um mecanismo essencial para a distribuição de tráfego pela blogosfera, ou seja, as páginas contempladas com maior audiência servem como "filtros", "portas de entrada" para que blogs menores se tornem mais visíveis, como foi explicado no item 2.3 do trabalho. Nada disso ocorreu no campo da segunda análise de conteúdo desta pesquisa: dos 318 links concedidos pelos quatro blogs nos dois períodos de análise, nenhum foi destinado a um blogueiro desconhecido. 
Neste contexto, a proposição de Vivo (2008, p.3), transcrita abaixo, não nos parece exagerada. Para ele, a grande imprensa utiliza blogs

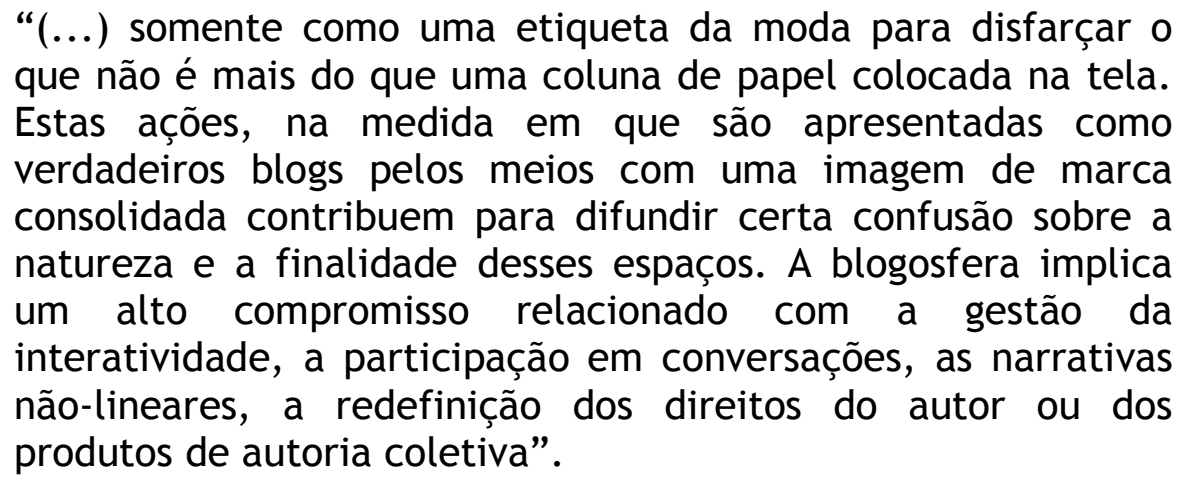
que não é mais do que uma coluna de papel colocada na tela. Estas ações, na medida em que são apresentadas como verdadeiros blogs pelos meios com uma imagem de marca consolidada contribuem para difundir certa confusão sobre a natureza e a finalidade desses espaços. A blogosfera implica um alto compromisso relacionado com a gestão da interatividade, a participação em conversações, as narrativas não-lineares, a redefinição dos direitos do autor ou dos produtos de autoria coletiva".

Os dados desta pesquisa apontam para duas constatações: em 2006, os brasileiros que não procuraram ou fizeram buscas específicas para descobrir blogs que versassem sobre as eleições, limitando a informar-se pelos meios de comunicação de texto mais vendidos do país, tomaram contato com pouquíssimas novas vozes balbuciadas em blogs; por outro lado, não se pode dizer que os blogs de maior visibilidade adotaram princípios que auxiliassem o desenvolvimento de comunidades ou de blogs menos cotados na blogosfera. Em outras palavras, a prometida democratização da comunicação enxergada pelos entusiastas dos blogs não se concretizou no campo desta pesquisa. 


\section{Bibliografia}

\section{Livros e capítulos de livros:}

ANDERSON, C. A cauda longa. A nova dinâmica de marketing e vendas: como lucrar com a fragmentação dos mercados. Tradução de Afonso Celso da Cunha Serra. $3^{a}$ edição. Rio de Janeiro: Elsevier, 2006.

ANTÚNEZ, J. L. El impacto de la aparición de los gestores de contenidos (CMS). In: ROJAS, O.I. et al. Blogs: la conversación em Internet que está revolucionando médios, empresas y a ciudadanos. Madrid: Esic Editorial, 2005. P. 49-76.

BAUMAN, Z. Modernidade líquida. Tradução de Plínio Dentzien. Rio de Janeiro: Jorge Zahar, 2001.

BENKLER, Y. The wealth of networks: the social production transforms markets and freedom. Yale Press, 2006. Livro disponível em:

http://www.benkler.org/wonchapters.html. Acesso em 11 dez. 2006

CASTELLS, M. A sociedade em rede. A era da informação: economia, sociedade e cultura, v.1. Tradução de Roneide Venâncio Majer. $6^{a}$ edição. São Paulo: Paz e Terra, 1999.

COIMBRA, M. A mídia teve algum papel durante o processo eleitoral de 2006? In: LIMA, V. (org). A mídia nas eleições de 2006. $1^{\text {a }}$ edição. São Paulo: Fundação Perseu Abramo, 2007.

COUTINHO, M; FILHO, C.B; SAFATLE, V. Os usos das novas mídias na campanha presidencial de 2006. In: LIMA, V. (org). A mídia nas eleições de 2006. $1^{\text {a }}$ edição. São Paulo: Fundação Perseu Abramo, 2007.

CRUMLISH, C. The power of many. How the living web is transforming politics, business, and everyday life. Alameda (EUA): Sybex, 2004.

DUARTE, J; BARROS, A. (org). Métodos e técnicas de pesquisa em comunicação. São Paulo: Atlas, 2005.

GILLMOR, D. We the media: grassroots journalism by the people, for the people. Cambridge: O’Reilly, 2004.

HEWITT, H. Blog: entenda a revolução que vai mudar seu mundo (2005). Tradução de Alexandre Martins Moraes. Rio de Janeiro: Thomas Nelson Brasil, 2007.

IANNI, O. A era do globalismo. $8^{\text {a }}$ edição. Rio de Janeiro: Civilização Brasileira, 2004.

KOVACH, B; ROSENSTIEL, T. Os elementos do jornalismo. 2003. Tradução de Wladir Dupont. $2^{\mathrm{a}}$ edição. São Paulo: Geração Editorial, 2004.

LESSIG, L. Free culture. The nature and future of creativity. Nova York: Penguin Books, 2004. 
LÉVY, P. A inteligência coletiva. Por uma antropologia do ciberespaço. Tradução de Luiz Paulo Rouanet. São Paulo: Edições Loyola, 1998.

LÉVY, P. Las Technologies de l'intelligence. L'avenir de la pensée à l'ere informatique. Paris: Éditions la Découverte, 1990.

LOPES, M.I.V. Pesquisa em comunicação. 8ª edição. São Paulo: Edições Loyola, 2005.

MATTELART, A; MATTELART, M. História das teorias da comunicação. Tradução de Luiz Paulo Rouanet. $3^{a}$ edição. São Paulo: Loyola, 2000.

NEGROPONTE, N; A vida digital. Tradução de Sérgio Tellaroli. São Paulo: Companhia das Letras, 1995.

ORIHUELA, J. La revolución de los blogs. Primera edición. Madrid: Esfera Libros, 2006.

PERRET, R. Os blogs e a multiplicação das vozes. In: CAVALCANTI, M (org). Eu, Mídia. A era cidadã e o impacto da publicação pessoal no jornalismo. Rio de Janeiro: Opus, 2008.

REPORTERS WITHOUT BORDERS. Handbook for bloggers and cyber-dissidents. Setembro de 2005. Disponível em: http://cyber.law.harvard.edu/globalvoices/wp-

content/RSFBloggerGuide2005.pdf . Acesso em 10 out. 2005.

RHEINGOLD, H. Smart Mobs. The next social revolution. Cambridge (EUA): Basic Books, 2002.

ROJAS, O.I. et al. Blogs: la conversación em Internet que está revolucionando médios, empresas y a ciudadanos. Madrid: Esic Editorial, 2005.

RODRIGUES, C. Blogs e a fragmentação do espaço público. Covilhã: Livros Labcom, 2006.

SASSI, S. The transformation of the public sphere. In: BARRIE, A; HUGGINS, H (org). New media and politics. Sage Publications: 2001. P. 89-109. Disponível em:

http://www.valt.helsinki.fi/staff/ssassi/thesis/X_TRANSFORMATION.html . Acesso em 20 ago. 2008

SALAVERRÍA, R; (coord.). Cibermedios: El impacto de Internet em los médios de comunicación em España. Sevilla: Comunicación Social Ediciones y Publicaciones, 2005.

SCHITTINE, D. Blog: comunicação e escrita íntima na Internet. Rio de Janeiro:

Civilização Brasileira, 2004.

SERRA, P. O on-line nas fronteiras do jornalismo: uma reflexão a partir do tabloidismo.net de Matt Drudge. In: FIDALGO, A; SERRA, P (org). Informação e Comunicação Online (vol I): Jornalismo Online. Universidade da Beira Interior: Covilhã, 2003. P. 91-108. Disponível em: http://www.bocc.ubi.pt/pag/serra-paulo-matt-

drudge.pdf. Acesso em 18 mai. 2007 
SERRA, P. A Internet e o mito da visibilidade universal. In: CAMILO, E. Informação e Comunicação Online (vol II): Internet e Comunicação promocional. Universidade da Beira Interior: Covilhã, 2003. P. 73-89. Disponível em:

http://www.bocc.ubi.pt/pag/serra-paulo-internet-mito-visibilidade-universal.pdf. Acesso em 18 mai. 2007.

SILVEIRA, S.A. Combates na fronteira eletrônica: a Internet nas eleições de 2006. In: LIMA, V. (org). A mídia nas eleições de 2006. $1^{\text {a }}$ edição. São Paulo: Fundação Perseu Abramo, 2007.

TRAQUINA, N. Teorias do Jornalismo. A tribo jornalística - uma comunidade interpretativa transnacional, v.2. $1^{\text {a }}$ edição. Florianópolis: Insular, 2005.

TALESE, G. O Reino e o Poder: uma história do New York Times. 1971. São Paulo: Schwarcz, 2000.

VARELA, J. Periodismo participativo: el periodismo 3.0. In: ROJAS, O.I. et al. Blogs: la conversación em Internet que está revolucionando médios, empresas y a ciudadanos. Madrid: Esic Editorial, 2005. P. 77-163.

WOLTON, D. As novas tecnologias, o indivíduo e a sociedade. In: Internet. E depois?: uma teoria crítica das novas mídias. Tradução de Isabel Crossetti. Porto Alegre: Editora Sulina, 2003. p. 83-118.

\section{Teses e dissertações:}

ARAUJO, A.V. Weblog e jornalismo: os casos de No Mínimo Weblog e Observatório de Imprensa (Bloi). São Paulo, 2006. 582 fl. Dissertação (Mestrado) - Escola de Comunicações e Artes, Universidade de São Paulo. Disponível em http: //www.icteba.org.br/Conteudo/Weblog\%20e\%20jornalismo\%20\%20os\%20casos\%20de \%20no\%20minimo\%20weblog\%20e\%20observatorio\%20da\%20imprensa\%20bloi.pdf. Acesso em 15 jun. 2007.

BERTOCCHI, D A narrativa jornalística no ciberespaço: transformações, conceitos e questões. Braga, 2006. 199 fl. Dissertação (Mestrado) - Instituto de Ciências Sociais, Universidade do Minho.

BRITTES, J.G. Internet, jornalismo e esfera pública: estudo sobre o processo comunicativo do ciberespaço na formação da opinião. São Paulo, 2003. $188 \mathrm{fl}$. Tese (Doutorado) - Escola de Comunicações e Artes, Universidade de São Paulo.

METZGER, M. Crowdsourced news: The collective intelligence of amateurs and the evolution of journalism. Londres, 2007. 59 fl. Dissertação (Master) - Department of Media and Comunications, London School of Economics and Political Science. Disponível em:

http://www.lse.ac.uk/collections/media@lse/mediaWorkingPapers/MScDissertationSeri es/Metzger_final.pdf . Acesso em 20 ago.2008. 
O'DONNEL, P.W. Users and the marketing efficacy of MP3 music blogs. Florida, 2006. $50 \mathrm{fl}$. Dissertação (Master) - College of Communications, The Florida State University. Disponível em: http://etd.lib.fsu.edu/theses/available/etd-04102006133400/unrestricted/ODonnellThesis.pdf. Acesso em 15 jun. 2007.

ROMANO, P.R. Pílulas digitais: a influência dos blogs na comunicação. São Paulo, 2005. $82 \mathrm{fl}$. Monografia (Trabalho de Conclusão de Curso) - Curso de Relações Públicas, Escola de Comunicações e Artes, Universidade de São Paulo.

SANT'ANNA, L. O jornal na sociedade da informação: como a Folha, o Globo e o Estado respondem às inovações tecnológicas, à queda de leitura e à concorrência de novos meios. São Paulo, 2007. 120 fl. Dissertação (Mestrado) - Curso de Jornalismo, Escola de Comunicações e Artes, Universidade de São Paulo.

TERRA, C.F. Comunicação corporativa digital: o futuro das relações públicas na rede. São Paulo, 2006. $173 \mathrm{fl}$. Dissertação (Mestrado) - Curso de Relações Públicas, Escola de Comunicações e Artes, Universidade de São Paulo. Disponível em:

http://poseca.incubadora.fapesp.br/portal/bdtd/2007/2007-me-terra_carolina.pdf . Acesso em 1.jan. 2009

Artigos acadêmicos, relatórios e reportagens de jornais, revistas e sites de Internet:

ADAMIC, L; GLANCE, N; The political blogosphere and the 2004 U.S. election: divided they blog. Março de 2005. Disponível em:

http://www.blogpulse.com/papers/2005/AdamicGlanceBlogWWW.pdf . Acesso em 08 dez. 2005.

ADGHIRNI, Z. Informação online: jornalista ou produtor de conteúdos? Mudanças estruturais no jornalismo. In: INTERCOM - XXIV CONGRESSO BRASILEIRO DE CIẾNCIAS DA COMUNICAÇÃO. Campo Grande, 2001. Disponível em

http: //reposcom. portcom. intercom.org.br/bitstream/1904/4345/1/NP2ADGHIRNI.pdf. Acesso em 16 fev. 2008.

ALBA, G.A. Los blogs no amenazan al periodismo. Dialogos de la comunicación, Primeiro semestre de 2008. Disponível em:

http://www.dialogosfelafacs.net/76/articulos/pdf/76GerardoAlbarran.pdf . Acesso em 5 ago. 2008.

ALDÉ, A; CHAGAS, V. Blog de política e identidade jornalística (transformações na autoridade cognitiva e na relação entre jornal e leitor). In: NP 02 - V ENCONTRO DOS NÚCLEOS DE PESQUISA DA INTERCOM. Rio de Janeiro, 2005. Disponível em http://www.cem.itesm.mx/dacs/publicaciones/logos/anteriores/n49/bienal/Mesa\%206/ alexandraalde.pdf. Acesso em 06 ago. 2008.

ALTERMAN, E. O futuro dos jornais. Folha de S.Paulo, São Paulo, 8 jun. 2008. Caderno Mais, p.5-8.

AMARAL, I. A emergência dos weblogs enquanto novos actores sociais. Prisma.Com, $\mathrm{n}^{\circ} 3$, outubro de 2006, p 42-63. Disponível em: 
http://prisma.cetac.up.pt/artigospdf/3_ines_amaral_prisma.pdf . Acesso em 5 ago. 2008.

BALTATZIS, P. Is blogging innovating Journalism?, in CONFERENCE ON INNOVATION JOURNALISM, 3, 2006, Stanford (EUA). Innovation Journalism, v.3. Disponível em: http://www.innovationjournalism.org/archive/INJO-3-4/baltatzis.pdf. Acesso em 27 abr. 2007

BERTOCCHI, D. Um mês de olho nas fonts de "Toda Mídia": estudo sobre a coluna "Toda Mídia" veiculada no jornal brasileiro Folha de S.Paulo. In: CONGRESO INTERNACIONAL LUSOCOM, Santiago de Compostela (Espanha), 21 e 22 de abril de 2006. Anais. P. 46074629.

BLAKELY, R. World's 'biggest blogger' gets sporty, in Times Online - 10 fev.2006. Disponível em: http://www.timesonline.co.uk/article/0, 6-2034306,00.html. Acesso em 11 dez. 2006

BLOOD, R. A Few thoughts on journalism and what can weblogs do about it. Abril de 2004. Disponível em http://www.rebeccablood.net/essays/what_is_journalism.html. Acesso em 17 out. 2005.

BLOOD, R. Weblogs and journalism in the age of participatory media. Setembro de 2003. Disponível em http://www.rebeccablood.net/essays/weblogs_journalism.html. Acesso em 17 out. 2005.

BLOOD, R. Weblogs: a history and perspective. Setembro de 2000. Disponível em http://www.rebeccablood.net/essays/weblog_history.html. Acesso em 19 mai. 2007.

BOLAÑO, C; BRITTOS, V. Blogosfera, espaço público e campo jornalístico: o caso das eleições presidenciais brasileiras de 2006. In: III JORNADAS INTERNACIONAIS DE JORNALISMO. Porto (Portugal), março de 2008. Disponível em http://pontomidia.com.br/raquel/arquivos/bolanobrittos.pdf . Acesso em 5.ago.2008.

BOUDREAU, T. Before you blog: legal and ethical concerns about joining the blogosphere. In: NEWSPAPERS AND COMMUNITY-BUILDING SYMPOSIUM XII. Oklahoma City (EUA), outubro de 2006. Disponível em http://huckboyd.jmc.ksu.edu/symposium/XII/Boudreau\%20Speaking\%20on\%20Blogging.p df . Acesso em 27 abr. 2007.

BOUSA, T. Jornalismo cidadão se consagra com a cobertura da tragédia na Virgínia. Abril de 2007. Agência EFE. Disponível em http://noticias.uol.com.br/ultnot/efe/2007/04/19/ult1766u21257.jhtm . Acesso em 22 jun. 2007.

BOWERS, C; STOLLER, M. Emergence of the progressive blogosphere: a new force in american politics. Agosto de 2005. Disponível em:

http://www.newpolitics.net/files/The-Emergence-of-the-Progressive-Blogosphere.pdf. Acesso em 25 abr. 2007. 
BOWMAN, S; WILLIS, C. We media: how audiences are shaping the future of news and information. The Media Center at The American Press Institute. Julho de 2003.

Disponível em: http://www.newpolitics.net/files/The-Emergence-of-the-Progressive-

Blogosphere.pdf. Acesso em 25 abr. 2007.

BRAMBILLA, A.M. Jornalismo open source em busca de credibilidade: como funciona o projeto coreano OhmyNews International. ENCONTRO DOS NÚCLEOS DE PESQUISA DO INTERCOM, 2005. Disponível em:

http://reposcom.portcom.intercom.org.br/handle/1904/17851. Acesso em 27 mar. 2007.

BORGES, J. Blogs de política, blogs de politicos e a influência na cobertura jornalística. In: CONGRESSO DA ASSOCIAÇÃO BRASILEIRA DE PESQUISADORES EM COMUNICAÇÃO E POLÍTICA, 2, Belo Horizonte, dezembro de 2007. Anais. Disponível em http://www.fafich.ufmg.br/compolitica/anais2007/gt_ip-juliano.pdf. Acesso em 10 nov. 2008.

BROCANELLI, R. Uma aposta de cinco anos. Observatório da Imprensa, julho de 2002. Disponível em:

http://observatorio.ultimosegundo.ig.com.br/artigos/eno030720021.htm. Acesso em 18 out. 2005.

BROOKS, C; MONTANEZ, N. An analysis of the effectiveness of tagging in blogs. Março de 2006. Disponível em http://www.cs.usfca.edu/ brooks/papers/tagging-paper.pdf . Acesso em 25 fev. 2007.

BUTTERWORTH, T. A pornografia da opinião. Folha de S.Paulo, São Paulo, 14 mai. 2006. Caderno Mais, p.5.

CAMBRONERO, A. Los weblogs y la blogosfera. In: ORIHUELA, J.L. La revolución de los blogs. Primera edición. Madrid: Esfera Libros, 2006. p. 11-26.

PLEDEL, I. Les blogs, les promesses d'un media à travers ses representations collectives: illusions ou réalités à portée de clic? 31 mar.2006. Disponível em: http://archivesic.ccsd.cnrs.fr/docs/00/06/71/45/DOC/ArticlePLEDELiannisArchivSic.doc . Acesso em 13 ago. 2008.

CANAVILHAS, J. Political blogs in Portugal. Has the device created new actors? 2006. Disponível em: http://www.bocc.ubi.pt/pag/canavilhas-joao-political-blogs-inportugal.pdf. Acesso em 13 ago. 2008.

CASCIARI, H. El blog en la literatura. Un acercamiento estructural a la blogonovela. Telos, n.65, outubro-dezembro de 2005. Disponível em:

http: / / www.campusred.net/telos/articulocuaderno. asp?idarticulo $=5 \& r e v=65$. Acesso em 15 jun. 2007.

CHAPARRO, C. Internet é aliada, não inimiga. Abril de 2005. Disponível em http: / /observatorio.ultimosegundo.ig.com.br/artigos. asp?cod=326ASP008. Acesso em 28 mai. 2007. 
CHRISTOFOLETTI, R; LAUX, A. Em busca da credibilidade: monitoramento de cinco blogs brasileiros. Communicare, Vol.6, $\mathrm{n}^{\circ} 2$. Segundo semestre de 2006. Disponível em: http://www.facasper.com.br/cip/communicare/edicao_6_2/pdf/08.pdf Acesso em 5 ago. 2008.

CONCEIÇÃO, J.R.N. Práticas e desafios do participatory journalism em blogs. In: CONGRESSO IBEROAMERICANO DE PERIODISMO EM INTERNET. Salvador (Brasil), novembro de 2005. Disponível em http://www.pontoeletronico.fumec. br/artigos/pdf/03\%20\%20jorge\%20rocha_pj_pesquisa_intercom.pdf. Acesso em 25 fev. 2007.

CORNFIELD, M; CARSON, J et al. Buzz, blogs and beyond: The internet and national discourse in the fall of 2004. Dezembro de 2004. Disponivel em: http://www.pewinternet.org/ppt/BUZZ_BLOGS_BEYOND_Final05-16-05.pdf . Acesso em 08 dez. 2005.

CORRÊA, E. S. O jornalismo contemporâneo no Brasil: as mídias digitais como elo entre a crise e a busca de uma nova identidade. Razón y palavra, n 49, 2006, p.68-82. Disponível em:

http://www.cem.itesm.mx/dacs/publicaciones/logos/anteriores/n49/bienal/Mesa\%206/ elizabethsaad.pdf . Acesso em 26 jun. 2007.

CUNHA, M. Blogs: a remediação das mídias que permite à audiência publicar. Dialogos de la comunicación, Primeiro semestre de 2008. Disponível em: http://www.dialogosfelafacs.net/76/articulos/pdf/76MagdaRodrigues.pdf . Acesso em 6 ago. 2008.

CUNHA, M. Os blogs e a prática do Jornalismo no Brasil: uma reflexão sobre os meios, as linguagens e a cultura. Prisma.Com, $\mathrm{n}^{\circ} 3$, outubro de 2006. Disponível em http://prisma.cetac.up.pt/artigospdf/7_magda_cunha_prisma.pdf . Acesso em 27 abr.2007.

DA SILVA, H. N. Blogues: a experiência portuguesa. Fevereiro de 2005. Disponível em http://blog.lisbonlab.com/estudos/blogues-experiencia-portuguesa/. Acesso em 11 jun. 2007.

DAVIS, A. Ways to use weblogs in education. Outubro de 2004. Disponível em: http: //anvil.gsu.edu/EduBlogInsights/2004/10/05 . Acesso em 29 nov. 2005.

DELWICHE, A. Agenda-setting, opinion leadership ant the worlkd of weblogs. In: ANNUAL CONVENTION OF THE INTERNATIONAL COMMUNICATION ASSOCIATION. NeW Orleans (EUA), dezembro de 2005. Disponível em http://www.firstmonday.org/issues/issue10_12/delwiche/index.html. Acesso em 18 mai. 2007.

DITYATKINA, E.I. Blogosfera em Rusia. Dialogos de la comunicación, Primeiro semestre de 2008. Disponível em:

http: //www.dialogosfelafacs.net/76/articulos/pdf/76Elenalgorevna.pdf . Acesso em 5 ago. 2008. 
DODES, R. Bloggers get under the tent. The Wall Street Journal Online, Nova lorque (EUA), 12 set. 2006. Disponível em http: //online.wsj.com/public/article/SB115801727410860002-

T8jdDhY1KUeF_z3Yc_hdj8KweQE_20070912.html?mod=tff_main_tff_top. Acesso em 23 jun. 2007.

DREZNER, D; FARRELL, H. The power and politics of blogs. Agosto de 2004. Disponível em http://www.danieldrezner.com/research/blogpaperfinal.pdf . Acesso em 7 mar.2006.

EFIMOVA, L. Blogs: the stickiness factor. In: BLOGTALK - A EUROPEAN CONFERENCE ON WEBLOGS. Viena (Áustria), Maio de 2003. Disponível em https://doc.telin.nl/dscgi/ds.py/Get/File-34088. Acesso em 18 jun. 2007.

EFIMOVA, L; MOOR, A. Beyond personal webpublishing: na exploratory study of conversational blogging practices. In: HAWAII INTERNATIONAL CONFERENCE ON SYSTEM SCIENCES, 38, Havaí, 2005. Anais. Disponível em https://doc.telin.nl/dscgi/ds.py/Get/File-44480. Acesso em 18 jun. 2007.

ENGBERG, E. Blogging as typing, not journalism. CBS News, novembro de 2004. Disponível em:

http://www.cbsnews.com/stories/2004/11/08/opinion/main654285.shtml. Acesso em 3 nov. 2005.

ESCOBAR, J. Blog do Noblat e escândalo midiático: jornalismo sobre novas bases. UNIrevista, v.1, $\mathrm{n}^{\circ} 3$, julho de 2006, p.1-12. Disponível em http://www.unirevista.unisinos.br/_pdf/UNIrev_Escobar.pdf . Acesso em 27 abr.2007.

ESPINOSA, C. “Enlaza y serás enlazado”: José L. Orihuela. Maio de 2005. Disponível em http://www.coberturadigital.com/2005/05/23/enlaza-y-seras-enlazado-e-cuaderno/ . Acesso em 14 jun. 2007.

GERALDES, E.C. A vocação política dos blogs de notícias: possibilidade de recostrução da esfera pública? ENCONTRO DOS NÚCLEOS DE PESQUISA DO INTERCOM, 2005. Disponível em: http://reposcom.portcom.intercom.org.br/handle/1904/17382. Acesso em 27 mar. 2007.

GILL, K. Blogging, RSS and the information landscape: A look at online news. Maio de 2005. Disponível em http://faculty.washington.edu/kegill/pub/gill_blogs_rss_www2005.pdf . Acesso em 13 jun. 2007.

GILL, K. How can we measure the influence of the blogosphere? Maio de 2004. Disponível em http: //faculty.washington.edu/kegill/pub/www2004_blogosphere_gill.pdf . Acesso em 7 mar. 2006.

GLANCE, N; HURST, M; TOMOKIYO, T. BlogPulse: Automated trend discovery for weblogs. Maio de 2004. Disponível em http://www. blogpulse.com/papers/www2004glance.pdf . Acesso em 7 mar. 2006. 
GLAZER, M. Six lessons from online coverage of Hurricane Rita. Setembro de 2005. Disponível em http://www.ojr.org/ojr/stories/050927glaser/ . Acesso em 22 jun. 2007.

GLIKSMAN, O. Trackback in blogger. Setembro de 2006. Disponível em http: / /ohadnews.blogspot.com/2006/09/trackback-in-blogger.html . Acesso em 14 jun. 2007.

HAAS, T; STEINER, L. Public journalism: a reply to critics. Journalism, v.7, 2006, p. 238254. Disponível em: http://jou.sagepub.com/cgi/reprint/7/2/238 . Acesso em 26 abr.2007.

HAFNER, K. For some, the blogging never stops. The New York Times, Nova lorque (EUA), 27 mai. 2004. Tecnologia. Disponível em

http: / /query. nytimes.com/gst/ fullpage. html?sec=technology\&res=9C0CE0DA123EF934A1 5756C0A9629C8B63 . Acesso em 18 jun. 2007.

HARPER, C. Blogging and journalistic practice. Maio de 2005. Disponível em http://web.mit.edu/comm-forum/mit4/papers/harper.pdf. Acesso em 27 abr. 2007.

HERKENHOFF, G; MALINI, F. A disputa pela produção de sentidos nas eleições de 2006: a emergência de uma opinião distribuída. In: INTERCOM - XXIII CONGRESSO BRASILEIRO DE CIÊNCIAS DA COMUNICAÇÃO NA REGIÃO SUDESTE. Maio de 2008. Disponível em http://fabiomalini.files.wordpress.com/2008/04/artigo-iniciacom-gabriel.pdf. Acesso em 9 nov. 2008.

HERMIDA, A; THURMAN, N. Comments please: How the British news media are struggling with user-generated content. 2007. Disponível em http://online.journalism.utexas.edu/2007/papers/Hermida.pdf. Acesso em 25 ago. 2008.

HILER, J. Are bloggers journalists?. Maio de 2002. Disponível em http://www.microcontentnews.com/articles/bloggingjournalism.htm. Acesso em 18 out. 2005.

HILER, J. Blogosphere: the emerging media ecosystem. Maio de 2002. Disponível em http://www.microcontentnews.com/articles/blogosphere.htm. Acesso em 18 out. 2005.

HORRIGAN, J; GARRETT, K; RESNICK, P; The internet and democratic debate. Pew Internet \& American Life Project. Outubro de 2004. Disponível em:

http://www.pewinternet.org/pdfs/PIP_Political_Info_Report.pdf . Acesso em $08 \mathrm{dez}$. 2005.

HUANN, T.Y et al. Weblogs in education. 2005. Disponível em: http://www.moe.edu.sg/edumall/rd/litreview/weblogs_in_education.pdf . Acesso em 17 mar. 2006.

JARVIS, J. Defying definition. Buzzmachine, setembro de 2005. Disponível em http://www.buzzmachine.com/2005/09/30/defying-definition-2/. Acesso em 12 jun. 2007. 
JAVA, A et al. Why we twitter: understanding microblogging usage and communities. Agosto de 2007. Disponível em http://ebiquity.umbc.edu/paper/html/id/367/Why-WeTwitter-Understanding-Microblogging-Usage-and-Communities. Acesso em 4 nov. 2008.

JERECZEK-LIPINSKA, J. Le blog en politique - outil de democratie electronique participative?. Glottopol, $\mathrm{n}^{\circ}$ 10, julho de 2007, p.159-172. Disponível em:

http: //www.univ-

rouen.fr/dyalang/glottopol/telecharger/numero_10/gpl10_13tirvassen.pdf. Acesso em 15 ago. 2008.

JYH, P.W.U.H; LENG, T.Y. Weblog archives: achieving the recordness of web archiving. IN: DIGITAL CULTURE \& HERITAGE. Paris (França), setembro de 2005. Disponível em: http://www.ichim.org/ichim05/contenu/PDF/S04-Wu.pdf. Acesso em 23 jun. 2007.

KLUTH, A. Survey: new media. The Economist, Londres (Inglaterra), 20 abr. 2006. Disponível em http://economist.com/surveys/displaystory.cfm?story_id=6794156. Acesso em 23 jun. 2007.

LARA, T. Blogs educativos de comunicación en Iberoamérica. Dialogos de la comunicación, Primeiro semestre de 2008. Disponível em:

http://www.dialogosfelafacs.net/76/articulos/pdf/76TiscarLara.pdf . Acesso em 6 ago. 2008.

LARA, T. Blogs para educar. Usos de los blogs en una pedagogía constructivista. Telos, n.65, outubro-dezembro de 2005. Disponível em:

http: //www.campusred.net/telos/articulocuaderno.asp?idarticulo=2\&rev=65. Acesso em 13 jun. 2007.

LASICA, J. D. Blogs and journalism need each other. Nieman Reports, Outono de 2003, p. 70-75. Disponível em: http://nieman.harvard.edu/reports/03-3NRfall/70-

74V57N3.pdf . Acesso em 18 mai. 2007.

LASICA, J. D. Participatory journalism puts the reader in he driver's seat. Online Journalism Review, Agosto de 2003. Disponível em: http://www.ojr.org/ojr/workplace/1060218311.php . Acesso em 19 mai. 2007.

LASICA, J. D. What is participatory journalism? Online Journalism Review, Agosto de 2003. Disponível em: http://www.ojr.org/ojr/workplace/1060217106.php . Acesso em 19 mai. 2007.

LEMANN, N. Amateur hour. The New Yorker, agosto de 2006. Disponível em http://www.newyorker.com/archive/2006/08/07/060807fa_fact1. Acesso em 19 mai. 2007.

LOWREY, W. Mapping the journalism-blogging relationship. Journalism, v.7, 2006, p. 477-500. Disponível em: http://jou.sagepub.com/cgi/reprint/7/4/477.pdf . Acesso em 26 abr. 2007. 
LUSOLI, W. A second order medium? The Internet as a source of electoral information in 25 European countries. Information Polity, $n^{\circ} 10,2005$, p.247-265. Disponível em: http://iospress.metapress.com/index/8XX3FXTYVQLH3D5A.pdf . Acesso em 13 ago. 2008.

MADANSKI, M; ARENBERG, P. The State of the blogsphere. Technorati, junho de 2008. Disponível em: http://www.technorati.com/blogging/state-of-the-blogosphere/. Acesso em 4 nov. 2008.

MADDEN, M; FOX, S. Riding the waves of "web 2.0": more than a buzzword, but still not easily defined. Pew Internet \& American Life Project. Outubro de 2006. Disponível em: http://www.pewinternet.org/pdfs/PIP_Web_2.0.pdf . Acesso em 21 jun. 2007.

MALINI, F. A opinião pública distribuída: blogs e jornalismo nas eleições brasileiras de 2006. E Compós, Agosto de 2007, p. 1-21. Disponível em:

http://www.compos.org.br/seer/index.php/e-compos/article/viewFile/181/182. Acesso em 8 nov de 2008.

MANCINI, P. Para estudiantes de comunicación y periodismo: por qué un blog? Novembro de 2005. Disponível em http://www.pablomancini.com.ar/para-estudiantesde-comunicacion-y-periodismo-\%c2\%bfpor-que-un-blog/. Acesso em 15 jun. 2005.

MANOVICH, L. New media from Borges to html. The New Media Reader, MIT Press, 2002. Disponível em http://nothing.org/netart_101/readings/manovich.htm. Acesso em 25 abr. 2007.

MARLOW, C. Audience, structure and authority in the weblog community. MIT Media Laboratory, 2004. Disponível em http://web.media.mit.edu/ cameron/cv/pubs/0401.pdf. Acesso em 18 jun. 2007.

MÁRQUEZ, D.F. En buscal del sujeto extraviado: reflexiones em torno al estúdio de blogs. Dialogos de la comunicación, Primeiro semestre de 2008. Disponível em: http://dialogosfelafacs.net/77/articulos/pdf/76DorismildaFlores.pdf . Acesso em 5 ago. 2008.

MCGILL, D. The fading mystique of an objective press. The McGill Report, outubro de 2004. Disponível em http://www.mcgillreport.org/objectivity.htm . Acesso em 3 nov. 2005.

MCMANE, A. Where the young get the news. In: NEW MEDIA: THE PRESS FREEDOM DIMENSION CHALLENGES AND OPPORTUNITIES OF NEW MEDIA FOR PRESS FREEDOM. Paris (França), fevereiro de 2007. Disponível em http://www.wan-

press.org/IMG/pdf/background_paperEDITEDunescostyle.pdf. Acesso em 27 mar. 2007.

MESSNER, M; DISTASO, M.W. Agenda setting and publisher's image: the intermedia source cycle: agenda-setting implications of blogs. In: INTERNATIONAL AGENDA SETTING CONFERENCE. Bonn (Alemanha), outubro de 2006. Disponível em http://agendasetting.com/2006/case_studies/CASE\%20STUDY\%20Agenda\%20Setting\%20a nd\%20Publisher's\%20lmage\%20II.doc. Acesso em 25 mar. 2007. 
MISHNE, G; GLANCE, N. Leave a reply: an analysis of weblog comments. 2006. Disponível em http://www.blogpulse.com/www2006-workshop/papers/wwe2006blogcomments.pdf. Acesso em 13 jun. 2007.

MITCHELL, B; STEELE, B. Earn your own thrust, roll your own ethics: transparency and beyond. In: BLOGGING, JOURNALISM AND CREDIBILITY CONFERENCE. Cambridge (EUA), janeiro de 2005. Disponível em http://cyber.law.harvard.edu:8080/webcred/index.php?p=5. Acesso em 18 out. 2005.

MONTEZ, R; GAMA, J. Esfera pública e blogosfera: análise das relações entre a imprensa e a blogosfera ao nível do debate político. Prisma.com, n. 3. Outubro de 2006, p.504529. Disponível em: http://prisma.cetac.up.pt/artigospdf/26_rui_montez_prisma.pdf. Acesso em 27 fev. 2007.

MORAIS, L. A Internet como espaço público - Um olhar sobre o 'Blog do Noblat'. In: GT 1 - INTERCOM SUDESTE - XI SIMPÓSIO DE CIÊNCIAS DA COMUNICAÇÃO. Ribeirão Preto, 2006. Disponível em http: / /reposcom. portcom.intercom.org.br/dspace/bitstream/1904/19363/1/Larissa+Mo rais.pdf . Acesso em 16 fev. 2008.

MURLEY, B; ROBERTS, C. Biting the hand that feeds: Blogs and second-level agenda setting, 27 de abril de 2005. Disponível em http://bryanmurley.com/site/wpcontent/uploads/2007/01/murley-roberts605.pdf. Acesso em 19 ago. 2008.

NAKAJIMA, S; TATEMURA, J. et al. Discovering important bloggers based on analyzing blog threads. Maio de 2005. Disponível em http://www-

idl.hpl.hp.com/blogworkshop2005/nakajima.pdf . Acesso em 7 mar. 2006.

NEUMANN, J. The impact of the Internet on journalism. Dezembro de 2005. Disponível em http: / /journalism.utexas.edu/onlinejournalism/2006/papers/Julie.pdf

. Acesso em 26 abr. 2007.

NILSSON, S. The Function of Language to Facilitate and Maintain Social Networks in Research Weblogs. Umea Universitet, 2003. Disponível em http://www.eng.umu.se/stephanie/web/LanguageBlogs.pdf. Acesso em 18 jun. 2007.

O'REILLY, T. Web 2.0 compact definition: trying again. Dezembro de 2006. Disponível em http://radar.oreilly.com/archives/2006/12/web_20_compact.html. Acesso em 19 jun. 2007.

O'REILLY, T. What is web 2.0. Setembro de 2005. Disponível em http://www.oreillynet.com/pub/a/oreilly/tim/news/2005/09/30/what-is-web-20.html . Acesso em 26 abr. 2007.

OLIVEIRA, R.M.C. Aprendizagem mediada e avaliada por computador: a inserção dos blogs como interface na educação. In: $12^{\circ}$ CONGRESSO INTERNACIONAL DE EDUCAÇÃO À DISTÂNCIA. Florianópolis (Brasil), setembro de 2005. Disponível em http://www.abed.org.br/congresso2005/por/pdf/026tcc5.pdf. Acesso em 15 jun. 2007. 
ORIHUELA, J.L. Agregadores: los nuevos metamedios. Abril de 2004. Disponível em http://www.ecuaderno.com/archives/000258.php

. Acesso em 14 jun. 2007.

ORIHUELA, J.L. Blogging and the eCommunication Paradigms: 10 principles of the new media scenario. In: BLOGTALK: A EUROPEAN WEBLOG CONFERENCE. Viena (Áustria), maio de 2003. Disponível em

http://mccd.udc.es/orihuela/cost/orihuela_cost_paper.pdf. Acesso em 20 jun. 2007.

ORIHUELA, J.L. Periodismo participativo. E-cuaderno, outubro de 2004. Disponível em http: //www.ecuaderno.com/2004/10/21/periodismo-participativo/. Acesso em 19 mai. 2007.

ORIHUELA, J.L. et al. Revisiting the spanish blogosphere. In: BLOGTALK 2.0: A EUROPEAN WEBLOG CONFERENCE. Viena (Áustria), julho de 2004. Disponível em http://wiki.randgaenge.net/BlogTalks/TableOfContents2. Acesso em 17 out. 2005.

ORIHUELA, J.L. Weblogs: El medio y el mensaje. Nuestro Tiempo (Pamplona) - $\mathrm{n}^{\circ} 601$ 602, pgs 48-53. Julho/agosto de 2004.

OROSA, B. G; GARCÍA, J.C. Un análisis comparativo con la agenda mediática tradicional. Outubro de 2004. Disponível em

http: / / dialnet.unirioja.es/servlet/citart?info=link\&codigo=1064878\&orden=32597.

Acesso em 20 dez. 2007.

OUTING, S. News Before its time: websites, blogs publish exit poll data Tuesday projecting Kerry lead. Poynter Online, novembro de 2004. Disponível em http: / / www. poynter.org/content/content_view.asp?id=73841\&sid=50. Acesso em 4 nov. 2005.

OUTING, S. The 11 layers of citizen journalism. Poynter Online, junho de 2005.

Disponível em http://www.poynter.org/content/content_view. asp?id=83126. Acesso em 26 abr. 2007.

PALOMO, B. Periodistas iberoamericanos con voz en la blogosfera. Dialogos de la comunicación, Primeiro semestre de 2008. Disponível em:

http: //www.dialogosfelafacs.net/76/articulos/pdf/76BellaPalomo.pdf . Acesso em 5 ago. 2008.

PALOMO, B. Blogs em el espacio iberoamericano. Informe Tendencias, 2007. Disponível em: http://www.jorgejorquera.cl/blogs_espacio_iberoamericano.pdf . Acesso em 20 ago. 2008.

PENTEADO, C.L.C; SANTOS, M.B.P; ARAÚJO, R.P.A. O movimento Cansei na blogosfera: o debate nos blogs de política. In: COMPOLÍTICA, II, Belo Horizonte (Brasil), 5 a 7 de dezembro de 2007. Anais. Disponível em http://www.fafich.ufmg.br/compolitica/anais2007/gt_ip-rafael.pdf. Acesso em 20 ago. 2008. 
PLEDEL, I. Les blogs, les promesses d'un media à travers ses representations collectives: illusions ou réalités à portée de clic? 31 mar.2006. Disponível em: http: //archivesic.ccsd.cnrs.fr/docs/00/06/71/45/DOC/ArticlePLEDELiannisArchivSic.doc . Acesso em 13 ago. 2008.

POSNER, R. Bad News. The New York Times, Nova lorque (EUA), 31 jul. 2005. Livros. Disponível em

http: //www.nytimes.com/2005/07/31/books/review/31POSNER.html?ex=1182744000\&e $\mathrm{n}=00278 \mathrm{~b} 6 \mathrm{~b} 3 \mathrm{a} 644 d \mathrm{dcd} \& \mathrm{ei}=5070$. Acesso em 18 jun. 2007.

PRILLINGER, $\mathrm{H}$. Are you serious? The potential and the reality of weblogs as mass media, and why they matter. In: BLOGTALK 2.0: A EUROPEAN WEBLOG CONFERENCE. Viena (Áustria), julho de 2004. Disponível em http://wiki.randgaenge.net/BlogTalks/TableOfContents2. Acesso em 17 out. 2005.

PRIMO, A; SMANIOTTO, A.M.R. A conversação na comunidade de blogs insanus. In: CONGRESSO BRASILEIRO DE CIÊNCIAS DA COMUNICAÇÃO, 28, Rio de Janeiro (Brasil), setembro de 2005. Anais. Disponível em

http://reposcom.portcom.intercom.org.br/dspace/handle/1904/17831. Acesso em 18 jun. 2007.

PRIMO, A; TRÄSEL, M. Webjornalismo participativo e a produção aberta de notícias. In: VIII Congresso Latino-americano de Pesquisadores da Comunicação, 2006, São Leopoldo (Brasil). Anais, 2006.

PROJECT FOR EXCELLENCE IN JOURNALISM. The State of the News Media 2005: An Annual report on American Journalism. Disponível em:

http://www.stateofthemedia.org/2005/index.asp . Acesso em 8 dez. 2005.

PROJECT FOR EXCELLENCE IN JOURNALISM. The State of the News Media 2006: An Annual report on American Journalism. Disponível em: http://www.stateofthemedia.org/2006/index.asp . Acesso em 24 abr. 2007.

PROJECT FOR EXCELLENCE IN JOURNALISM. The State of the News Media 2007: An Annual report on American Journalism. Disponível em:

http://www.stateofthemedia.org/2007/index.asp . Acesso em 24 abr. 2007.

PROJECT FOR EXCELLENCE IN JOURNALISM. Blogs, a day in the life: 2006 annual report. Disponível em: http://www.journalism.org/node/865 . Acesso em 24 abr. 2007.

QUADROS, C.I.; ROSA, A.P.; VIEIRA, J. Blogs e as transformações do jornalismo. E Compós, agosto de 2005, p.1-27. Disponível em:

http: / /boston.braslink.com/compos.org.br/ecompos/adm/documentos/agosto2005_quadrosrosavieira.pdf . Acesso em 15 ago. 2008.

RAINIE, L; CORNFIELD, M; HORRIGAN, J; The internet and campaign 2004. Pew Internet \& American Life Project. Março de 2005. Disponível em:

http://www.pewinternet.org/pdfs/PIP_2004_Campaign.pdf . Acesso em 08 dez. 2005. 
RAMOS, D.O. A mídia de um homem só: aspectos da utilização de weblogs no Jornalismo Digital. Disponível em

http://njmt.incubadora.fapesp.br/portal/publi/danielao/midia-de-um-homem-so.pdf. Acesso em 25 abr. 2007.

READERSHIP INSTITUTE. Culture report: A profile of the impact newspapers ant their departments. Julho de 2000. Disponível em:

http://www.readership.org/culture_management/culture/data/final_culture_report.pd f. Acesso em 5 nov. 2008.

RECUERO, R.C. Redes Sociais na Internet: Considerações Iniciais. E Compós, v. 2, 2005, p. 1-20. Disponível em: http://www6.ufrgs.br/limc/PDFs/redes_sociais.pdf. Acesso em 18 jun. 2007.

RECUERO, R.C. Warblogs, os blogs, a guerra no Iraque e o jornalismo online. In: CONGRESSO BRASILEIRO DE CIÊNCIAS DA COMUNICAÇÃO, 26, Belo Horizonte (Brasil), setembro de 2003. Anais. Disponível em

http://reposcom.portcom.intercom.org.br/handle/1904/4752. Acesso em 18 out. 2005.

RECUERO, R.C. Webrings: as redes de sociabilidade e os weblogs. Famecos/PUCRS, n.11, Julho de 2004, p.19-27. Disponível em:

http: //caioba.pucrs.br/famecos/ojs/include/getdoc. php?id=408\&article=127\&mode=pdf . Acesso em 15 jun. 2007.

RENÓ, D.P; ESPERIDIÃO, M.C. Tecnologia, Internet e eleições americanas: Obama no front do ciberespaço. Razón y Palabra, $\mathrm{n}^{\circ}$ 63. Novembro de 2008. Disponível em: http://www.razonypalabra.org.mx/n63/varia/DPorto.html Acesso em 10 nov. 2008.

ROSEN, J.. Bloggers vs. Journalists is over. In: BLOGGING, JOURNALISM AND CREDIBILITY CONFERENCE. Cambridge (EUA), janeiro de 2005. Disponível em http://journalism.nyu.edu/pubzone/weblogs/pressthink/2005/01/21/berk_essy.html . Acesso em 11 out. 2005.

SALAVERRÍA, R. Los cibermedios ante las catástrofes: Del 11S al 11M. Anais do XIX Congreso Internacional de Comunicación da Universidade de Navarra. Pamplona, novembro de 2004. Disponível em:

http://www.unav.es/dpp/tecnologia/docs/salaverria_cicom2004.pdf . Acesso em 8 dez. 2005.

SALAVERRÍA, R. An immature medium: strenghts and weaknesses of online newspapers on September 11. Gazette: The International Journal for Communication Studies, v.67, Fevereiro de 2005, p.69-86, 2005. Disponível em:

http://cost-a20.iscte.pt/content/documents/Immature_medium_9_11.doc . Acesso em 25 abr. 2007.

SANTOS, L.A. A explosão dos weblogs em Portugal: percepcões sobre os efeitos no jornalismo. In: CONGRESSO IBÉRICO DE COMUNICAÇÃO, 2, Covilhã (Portugal), abril de 2004. Anais. Disponível em https://repositorium.sdum.uminho.pt/handle/1822/3065 . Acesso em 27 abr. 2007. 
SANTOS, L.C.; PINTO, M. Weblogs and journalism: un uneasy relation (the Portuguese case). Universidade do Minho - Departamento de Ciências da Comunicação. Disponível em: https://repositorium.sdum.uminho.pt/handle/1822/1004. Acesso em 17 out. 2005.

SCHMIDT, J. Blogging practices: an analytical framework. Journal of ComputerMediated Communication, $\mathrm{n}^{\circ} 12$, 2007, p.1409-1427. Disponível em: http://www3.interscience.wiley.com/cgi-bin/fulltext/117979361/PDFSTART . Acesso em 13 ago. 2008.

SCHNEIDER, S.M.; FOOT, K.A. The web as an object of study. New media \& society, v. 6. 2004, p. 114-122. Disponível em: http://nms.sagepub.com/cgi/reprint/6/1/114.pdf . Acesso em 25 abr. 2007.

SERRA, P. A relação entre os blogs e os outros media: o caso da blogosfera portuguesa. Prisma.com, n. 3. Outubro de 2006, p.530-553. Disponível em:

http://prisma.cetac.up.pt/artigospdf/28_paulo_serra_prisma.pdf. Acesso em $27 \mathrm{fev}$. 2007.

SHAW, R. Web 2.0? It doesn't exist. Dezembro de 2005. Disponível em: http: //blogs.zdnet.com/ip-telephony/?p=805. Acesso em 19 jun. 2007.

SHIRKY, C. Power Laws, weblogs and inequality. Fevereiro de 2003. Disponível em: http://shirky.com/writings/powerlaw_weblog.html. Acesso em 19 jun. 2007.

SHIRKY, C. The Music Business and the big flip. Janeiro de 2003. Disponível em: http://shirky.com/writings/music_flip.html. Acesso em 19 jun. 2007.

SIFRY, D. The State of the live web. Technorati, abril de 2007. Disponivel em: http://www.sifry.com/alerts/archives/000493.html. Acesso em 28 jun. 2007.

SIMÃO, J. Relação entre os Blogs e Webjornalismo. Prisma.Com, $n^{\circ}$ 3, outubro de 2006. Disponível em http://prisma.cetac.up.pt/artigospdf/9_joao_simao_prisma.pdf . Acesso em 27 abr.2007.

SINGER, J.B. The political J-Blogger: 'normalizing' a new media form to fit old norms and practices. Journalism, v.6, 2005, p. 173-198. Disponível em:

http://jou.sagepub.com/cgi/reprint/6/2/173 . Acesso em 26 abr. 2007.

THELWALL, M. Bloggers during the London attacks: Top information sources and topics. WWW2006 blog workshop, 2006. Disponível em: http: //www.blogpulse.com/www2006workshop/papers/blogs-during-london-attacks.pdf . Acesso em 17 mai. 2008.

TRAMMELL, J et al. Rzeczpospolita blogów (Republic of Blog): Examining polish bloggers through content analysis. Journal of Computer-Mediated Communication, $n^{\circ} 11,2006$, p.702-722. Disponível em:

http://jcmc.indiana.edu/vol11/issue3/trammell.html . Acesso em 25 ago. 2008.

TREMAYNE, J et al. Issue publics on the web: applying network theory to the war blogosphere. Journal of Computer-Mediated Communication, $n^{\circ} 12$, 2007, p.290-310. Disponível em: 
http://jcmc.indiana.edu/vol12/issue1/tremayne.html . Acesso em 25 ago. 2008.

TROTT, B; TROTT, M. Trackback: una introducción para principiantes. Dezembro de 2002. Tradução para o espanhol de Antonio Cambronero. Disponível em

http://www.blogpocket.com/tbbeginnerstrad.html . Acesso em 25 abr. 2007.

VAN DER WURFF, R. Impacts of the Internet on Newspapers in Europe: conclusions. Gazette: The International Journal for Communication Studies, v. 67. Fevereiro de 2005, p.107-120. Disponível em: http://gaz.sagepub.com/cgi/reprint/67/1/107. Acesso em 8 dez.2005.

VIVO, J.M.N. La percepción mediática de los blogs: Del miedo al intrusismo de los medios. Dialogos de la comunicación, Primeiro semestre de 2008. Disponível em: http://www.dialogosfelafacs.net/76/articulos/pdf/76JoseNoguera.pdf . Acesso em 6 ago. 2008.

XENOS, M. New mediated deliberation: blog and press coverage of the Alito nomination. Journal of Computer-Mediated Communication, $n^{\circ} 13$, 2008, p.485-503. Disponível em: http://www3.interscience.wiley.com/cgi-bin/fulltext/119414151/PDFSTART . Acesso em 25 ago. 2008.

WAKEFORD, N. Pushing at the boundaries of new media studies. New media \& society, v. 6. 2004, p. 130-136. Disponível em: http://nms.sagepub.com/cgi/reprint/6/1/130 . Acesso em 25 abr. 2007.

WALL, M. Blogs of war: weblogs as news. Journalism, v.6, 2005, p. 153-172. Disponível em: http://jou.sagepub.com/cgi/reprint/6/2/153 . Acesso em 26 abr. 2007.

WINER, D. The History of weblogs. Weblogs.com News. Maio de 2002. Disponível em http://oldweblogscomblog.scripting.com/historyOfWeblogs. Acesso em 11 jun. 2007. 